\title{
أحكام حقوق المؤلف والحقوق المجاورة \\ في القانون القطري
}

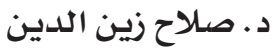

أستاذ القانون التجاري المشارك

كلية القانون- جامعة قطر

7تتاول هذه الدراسة الأحكام القانونية لحقوق المؤلف والحقوق المجاورة في القانون رقم

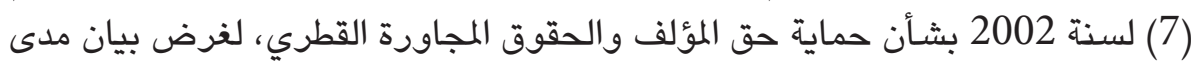

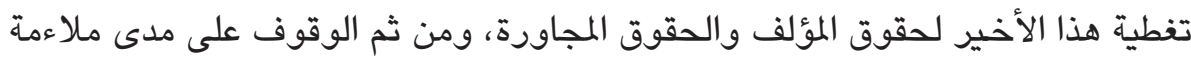

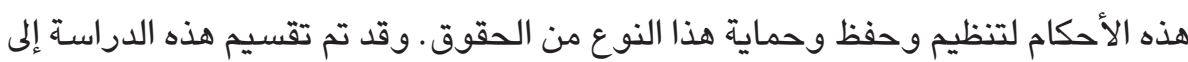

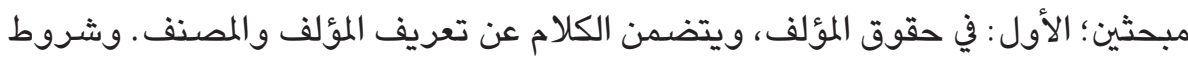

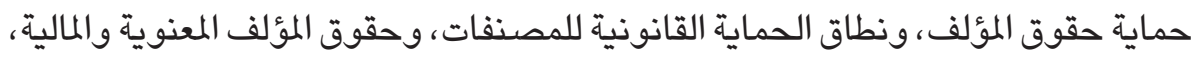

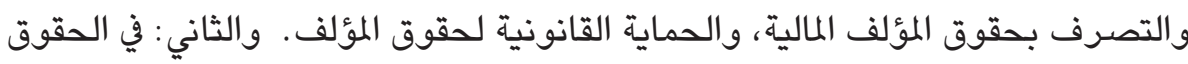

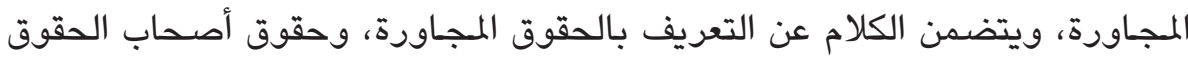

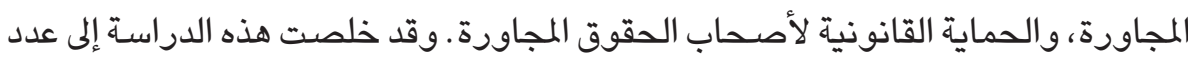

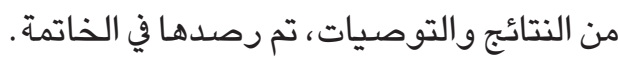

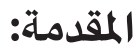

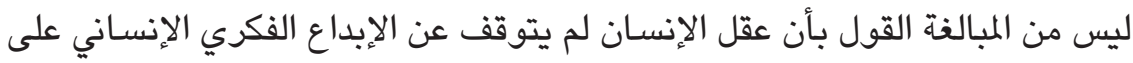

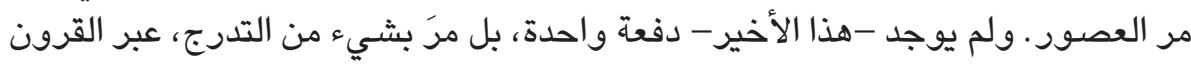

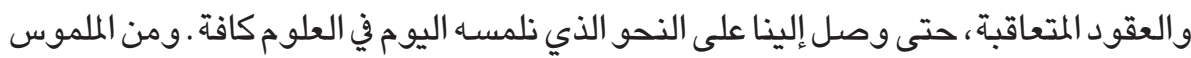

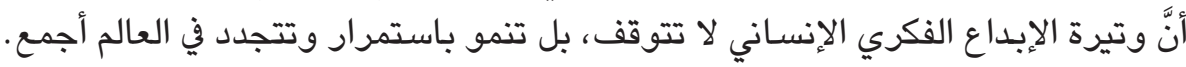

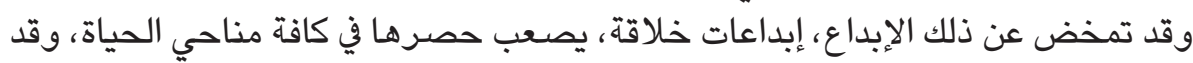

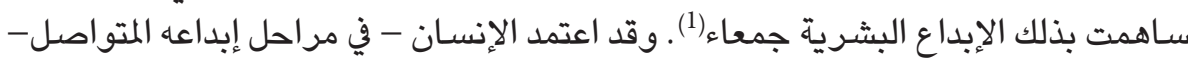

(1) فالإنجازات الإنسانية -وهي كثيرة- تشكل نماذج رائدة لإبداع الفكر الإنساني على مرّ العصور، وتتبئ

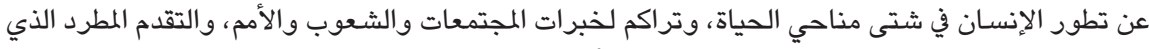

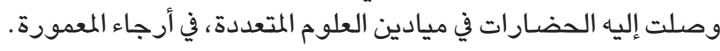


على الفكر والعلم والمعرفة، كوسائط ناجعة، في الوصول إلى ما وصل إليه من إبداع متعدد

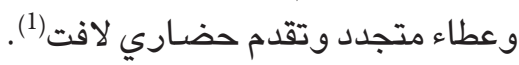

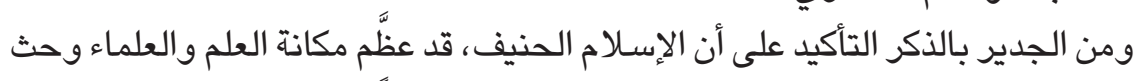

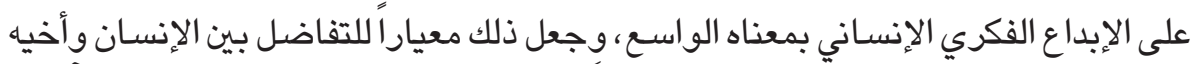

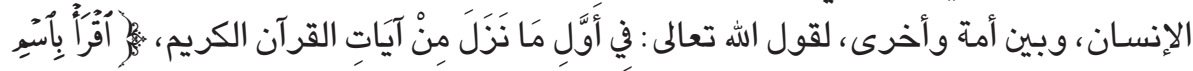

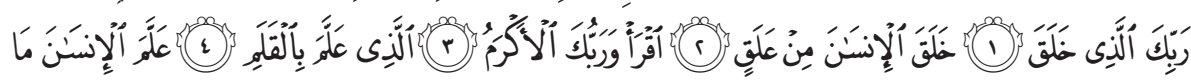

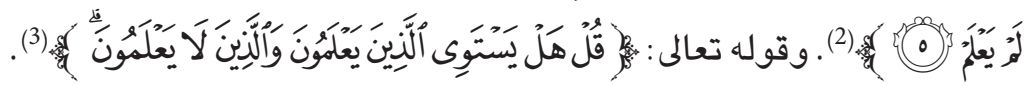

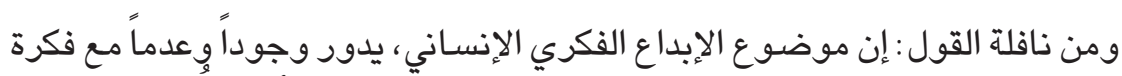

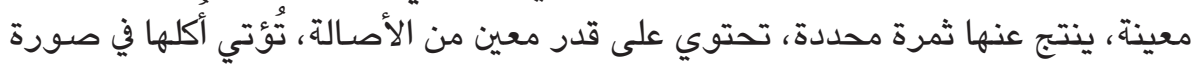

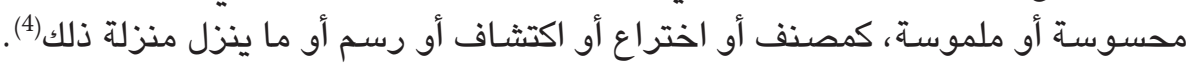

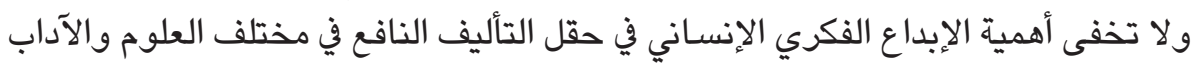

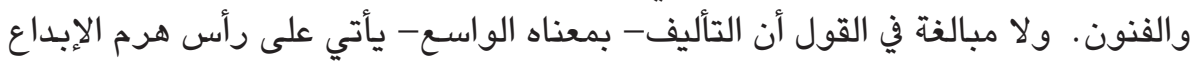

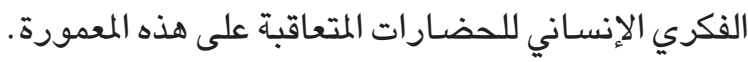

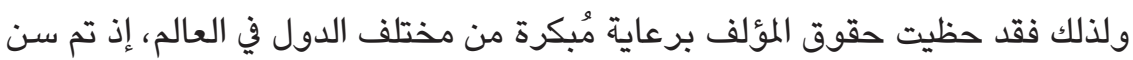

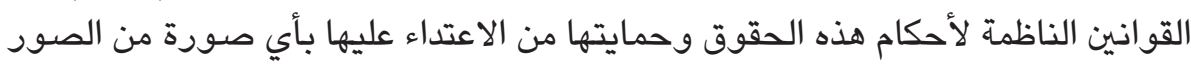

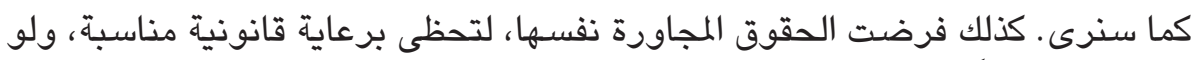

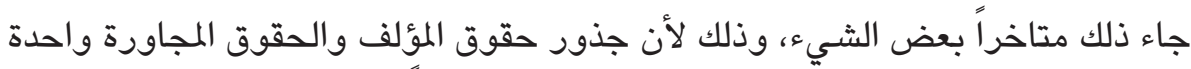

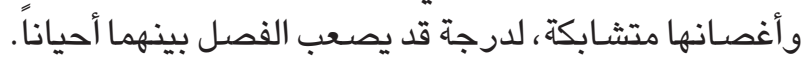

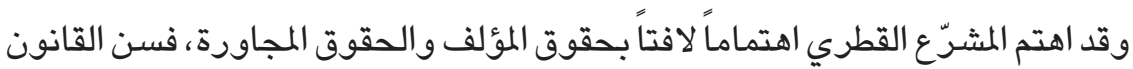

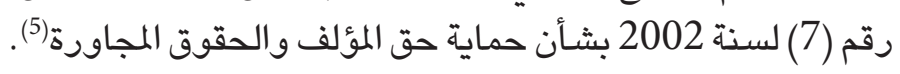

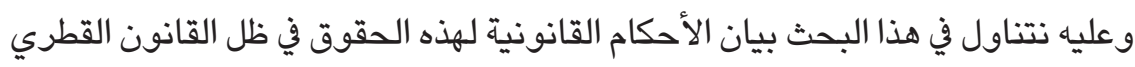

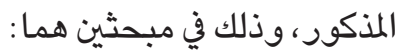

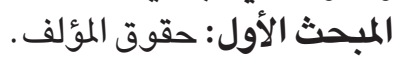

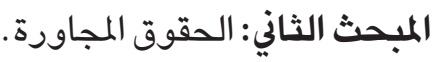

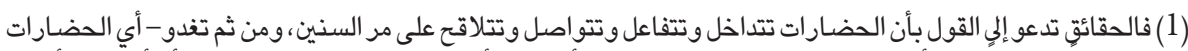

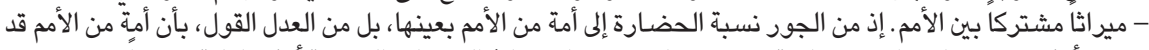

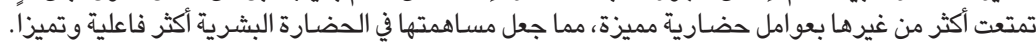

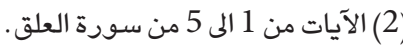

$$
\begin{aligned}
& \text { (3) الآية } 9 \text { من سورة الزمر. }
\end{aligned}
$$

(4) الدكتور صلاح زين الدين، المدخل إلى الملكية الفكرية، دار الثقافة، عمان، سنة 2004، الأردن، صانس 11 وما بعدها. (5) وسنشير له بالقانون القطري. 


\section{المبحث الأول \\ حقوق المؤلف}

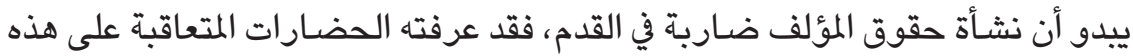

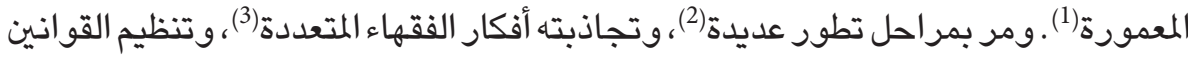

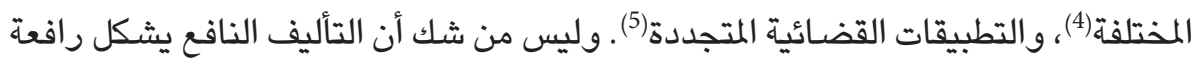

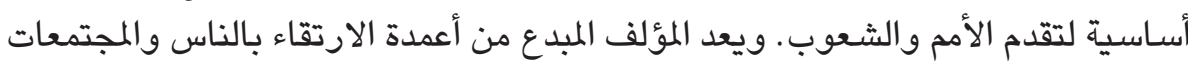

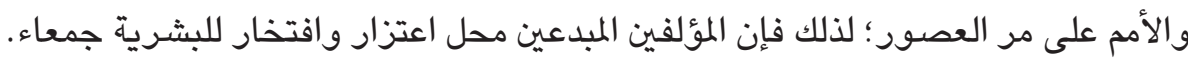

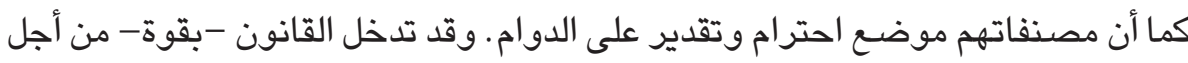

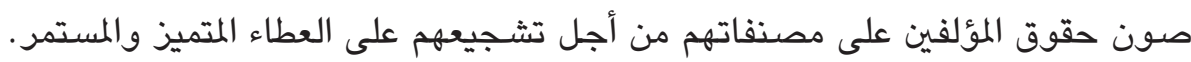

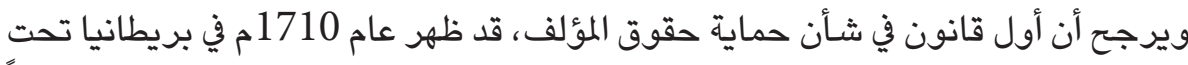

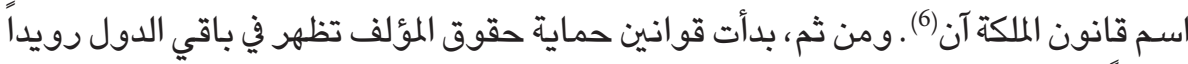

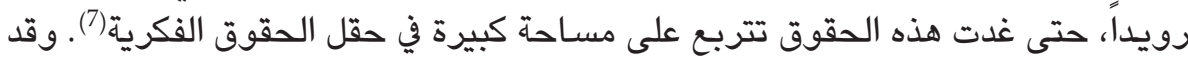
أضحى المؤلف يتمتع بجملة من الحقوق المعنوية والمالية على مصنفهاه (8).

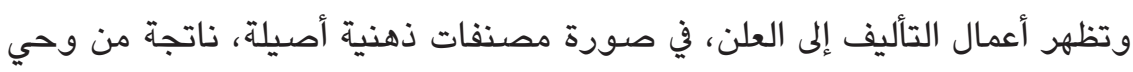

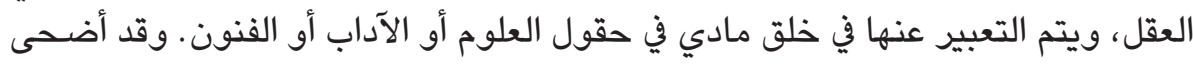
التأليف يفضي إلى نوعين من الحقوق ، وتتمثل في الآتي :

(1) الدكتور محمد حسام لطفي، المرجع العلمي في الملكية الأدبية والفنية في ضوء آراء الفقه وأحكام القضـاء، الكتاب

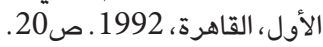

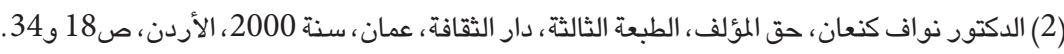

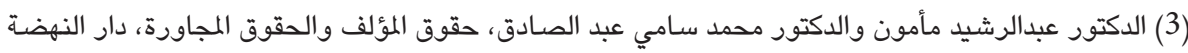

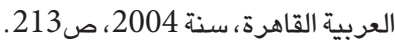

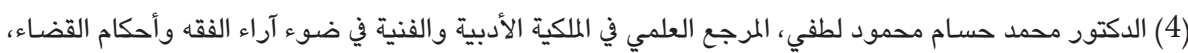

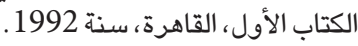

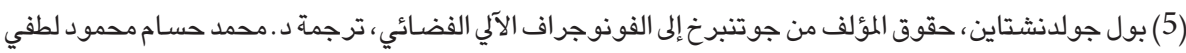

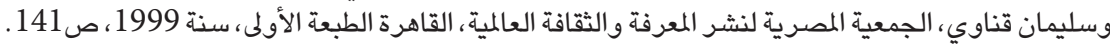

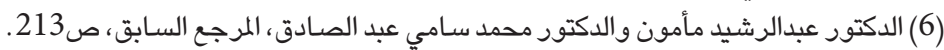

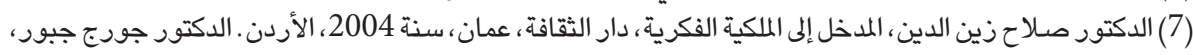

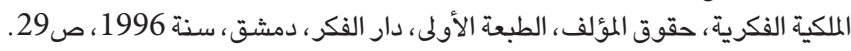

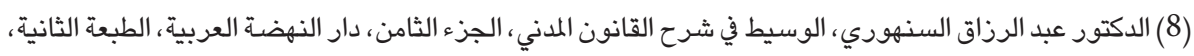

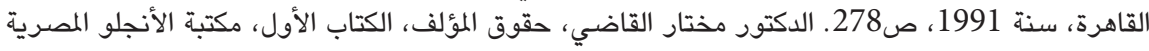

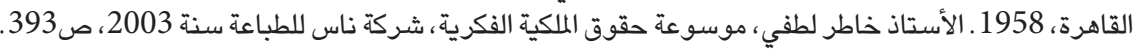




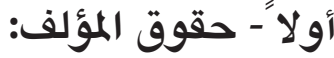

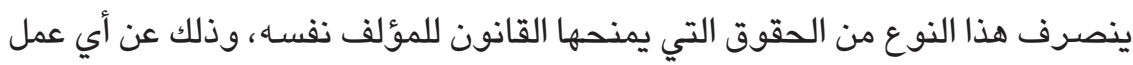

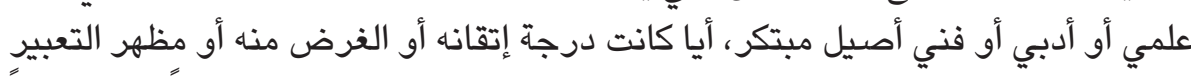

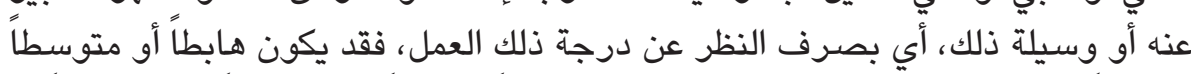

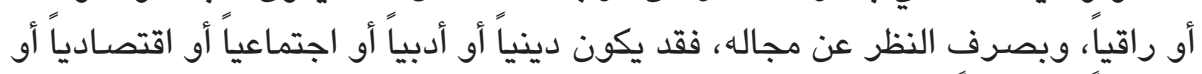

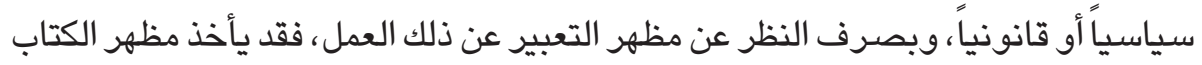

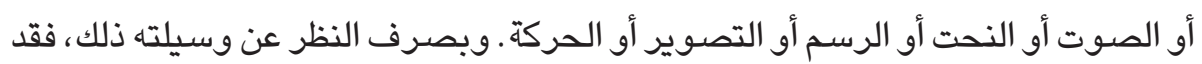

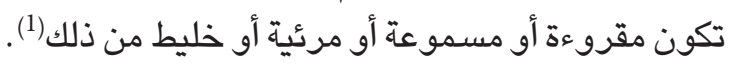

\section{ثانياً- حقوق مجاورة لحقوق المؤلف:}

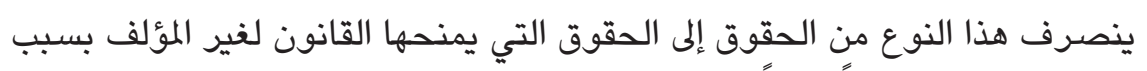

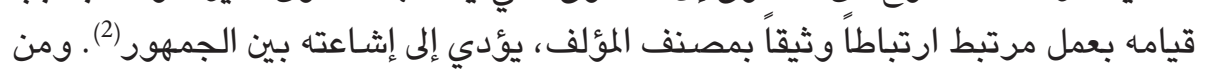
قبيل ذلك، فنانو الأداء ومنتجو التسجيلات السمعية وهيئات الإذاعة (3).

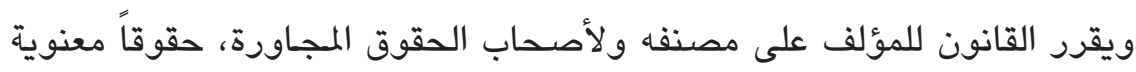

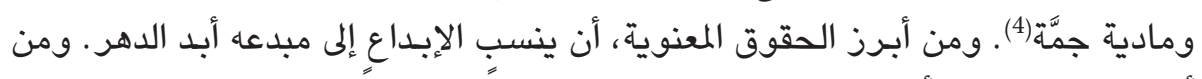

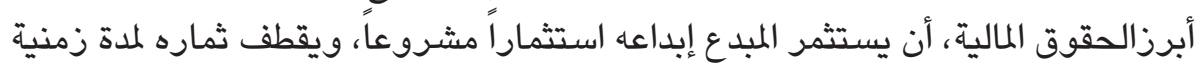

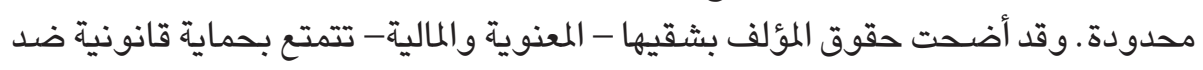

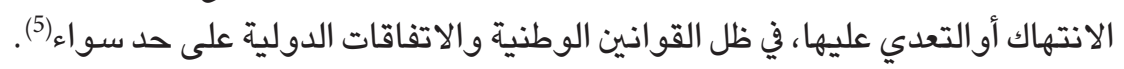
ونخصص هذا المبحث لدراسة حقوق المؤلف في القانون القطري في المطالب الآتية :

$$
\text { المطلب الأول: تعريف المؤلف والمصنف الثاني: شروط حماية حقوق المؤلف }
$$

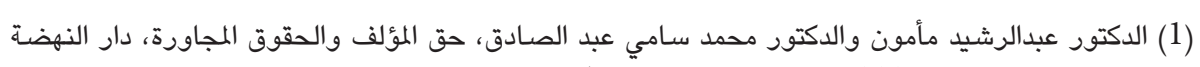

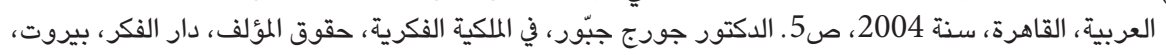

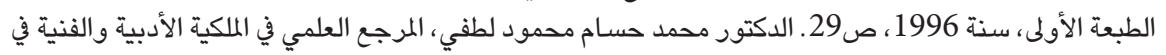

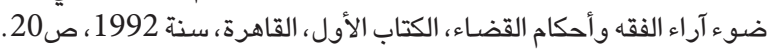
(2) الدكتور رمزي رشـاد عبدالرحمن الشيخ، الحقوق المجاورة لحق المؤلف، دار الجامعة الجديدة للنشر بالإسكندرية

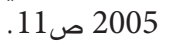
(3) المواد 40 و41 و 42 و 411 من القانون القطري

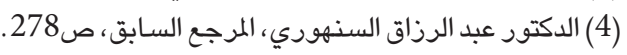

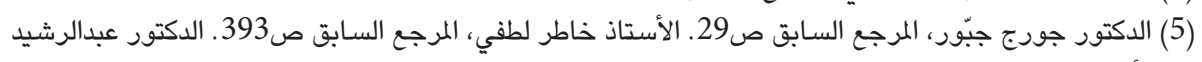

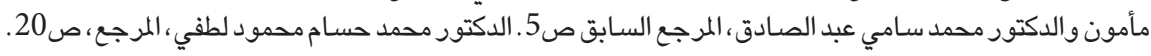


المطلب الثالث: نطاق الحماية القانونية للمصنفات المطلب الرابع: حقوق المؤلف المعنوية والمالية

المطلب الخامس: التصرف بحقوق المؤلف المالية

المطلب السـادس: الحماية القانونية لحقوق المؤلف

\section{المطلب الأول}

\section{تعريف المُصنَف والمُصنف (المُؤلف)}

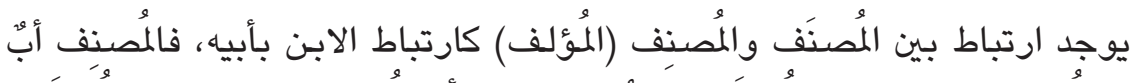

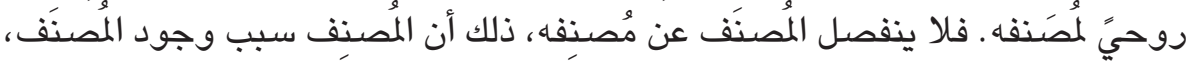

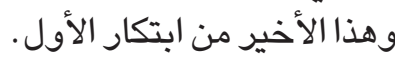
ونحاول في هذا المطلب تعريف المُصنَف ومن ثم تعريف المُصنف (المؤلف).

\section{الفرع الأول \\ تعريف المُصنَف}

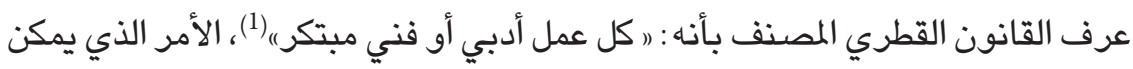

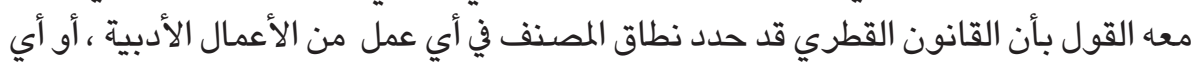

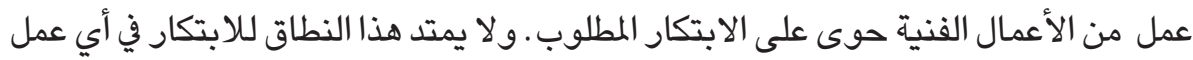

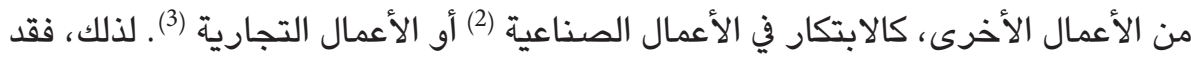

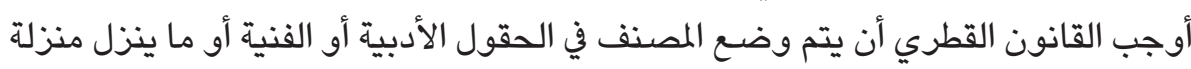

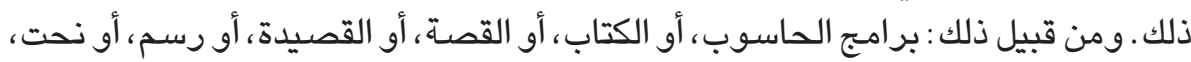
أو موسيقى ، أو نحو ذلك.

$$
\text { (1) (1) (المادة } 1 \text { من القانون القطري. }
$$

(2) ذلك أن الابتكار في الأعمال الصناعية يدخل في دائرة الحقوق الصناعية، ومن قبيل ذلك: براءات الاختراع والتصاميم الصناعية وما شـاكل ذلك. (3) ذلك أن الابتكار في الأعمال التجارية يدخل في دائرة الحقوق التجارية، ومن قبيل ذلك : العلامات التجارية والاسم التجاري وما شـاكل ذلك. 
ويبدو أن نطاق الأعمال الأدبية والفنية نطاق رحب، إذ ينصرف إلى (دكل إنتاج في المجال

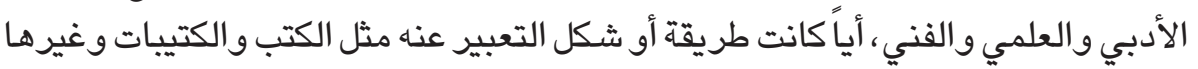

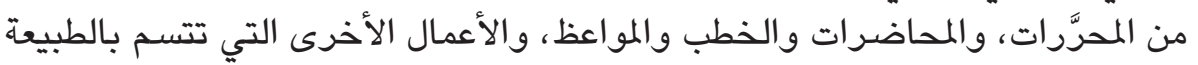

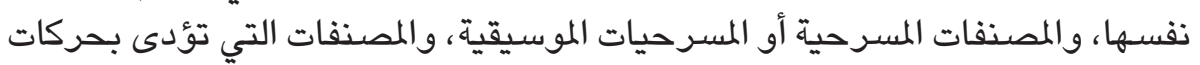

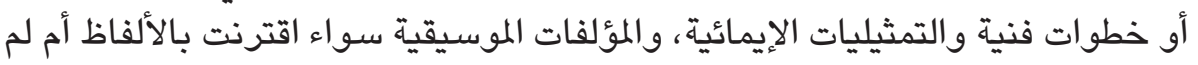

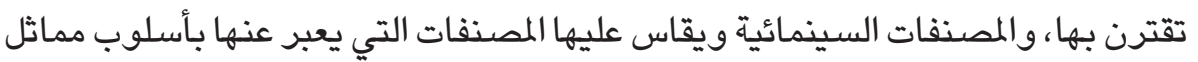

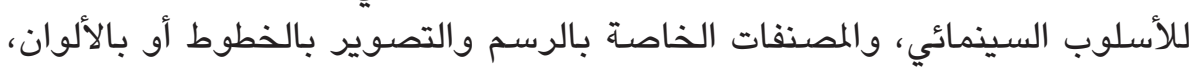

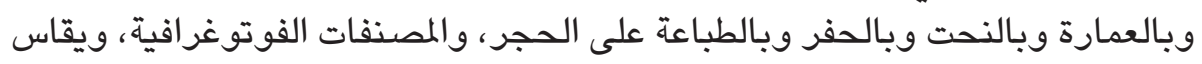

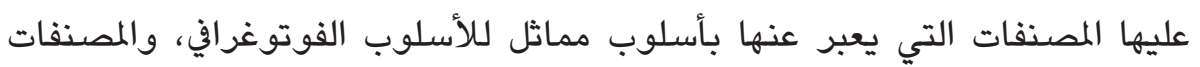

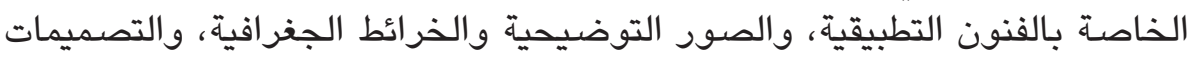

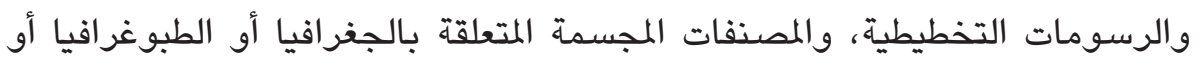
العمارة أو العلوم)|(1).

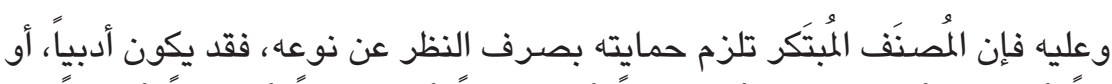

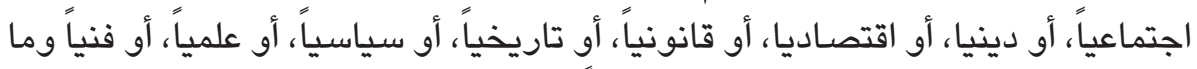

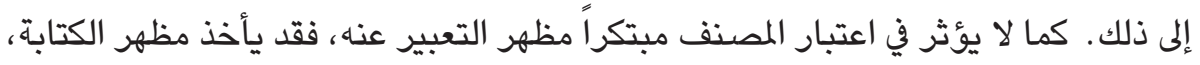

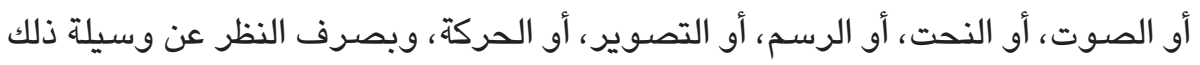

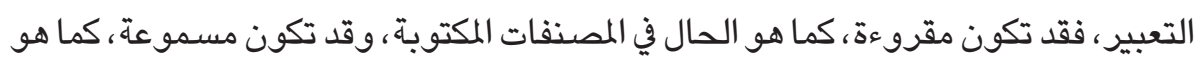

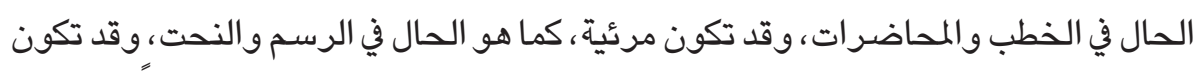

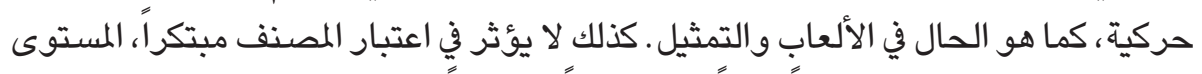

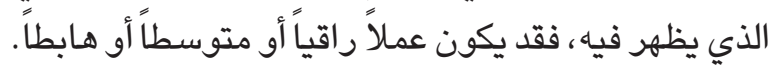

ويحمي القانون القطري ”الأعمال الأدبية والفنية“" المبتكرة بصرف النظر عن الصور

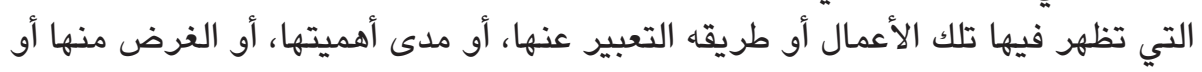

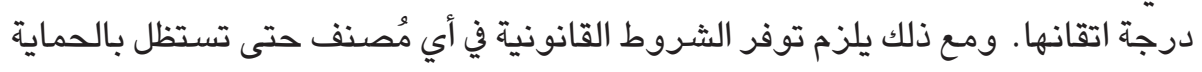

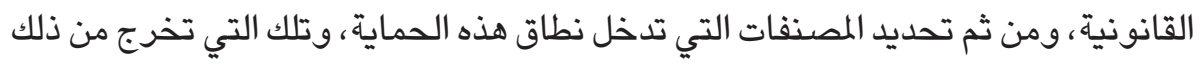

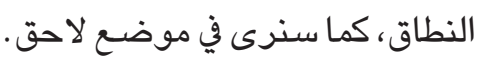

(1) المادة الثانية من اتفاقية برن لحماية المصنفات الأدبية والفنية لعام 1886. 


\section{الفرع الثاني \\ تعريف المؤلف}

عرف القانون القطري المؤُلِّف بأنه : (الشخص الطبيعي الذي ابتكر المُصنَف)|(1). ويعد

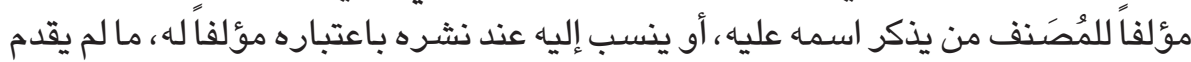

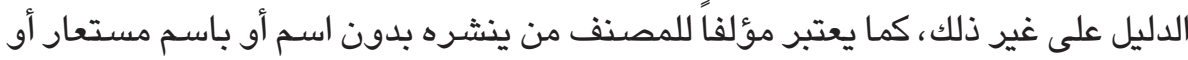

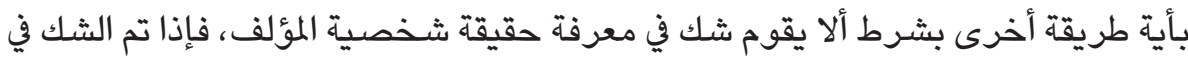

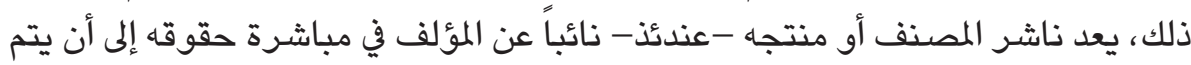

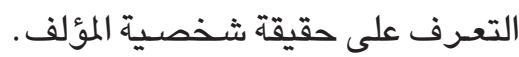

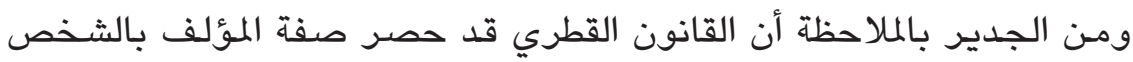

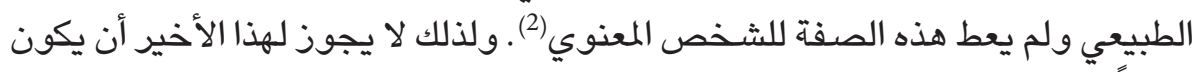

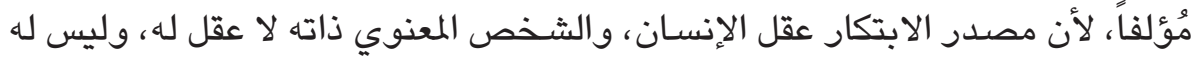

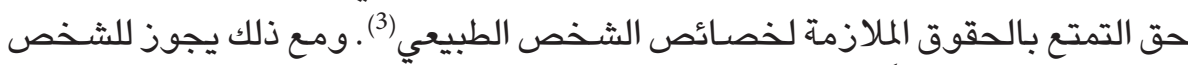

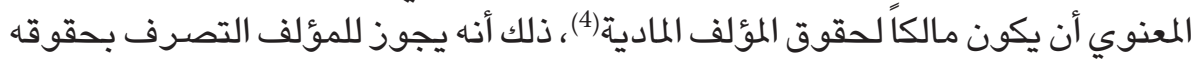

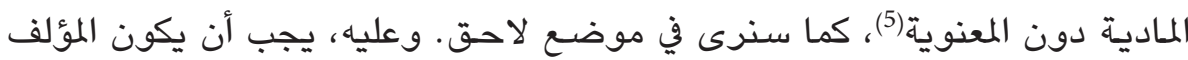

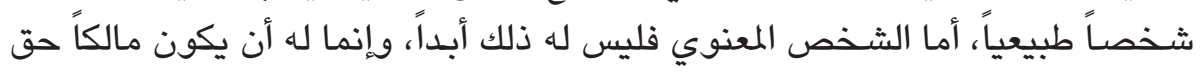
المؤلف المادي دون المعنوي.

(1) (1) (1) المادة 1 من القانون القطري.

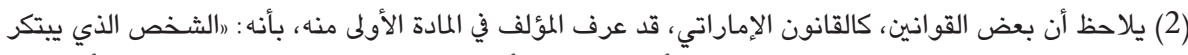

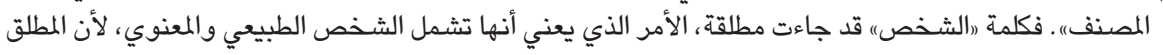
يجري على إطلاقه ما لم يقم الدليل على تقييده.

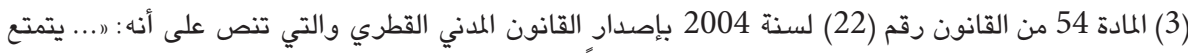

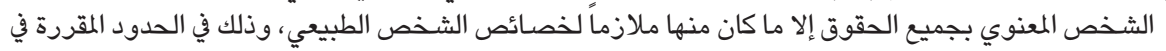




\section{الفرع الثالث}

\section{حالات التأليف}

قد يتم ابتكار المصنف - في الواتع العملي- من قبل مؤلف واحد، أو يشترك فيه عدة

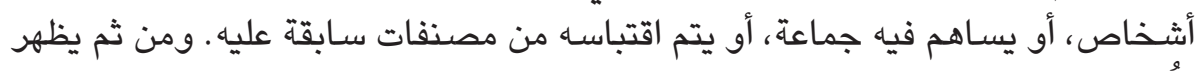

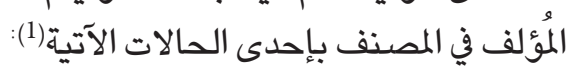

\section{1- حالة وضـع المصنف من مؤلف منفرد (المصنف الفردي) :}

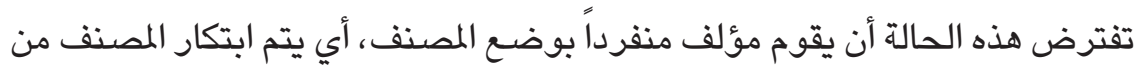

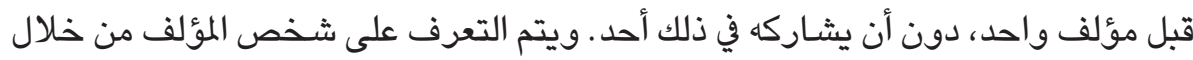

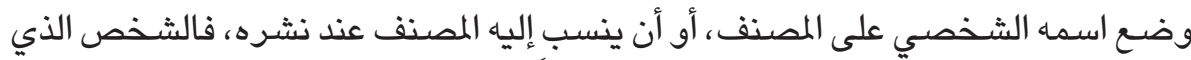

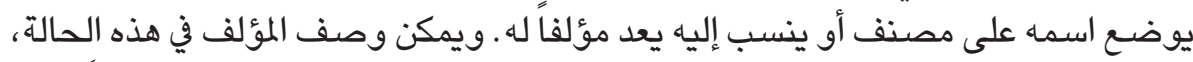
بالمؤلف الظاهر(المعلن)، الأمر الذي يقتضي أن يكون الاسم الظاهر (المعلن) موافقاً واتع

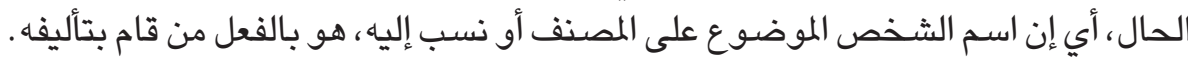

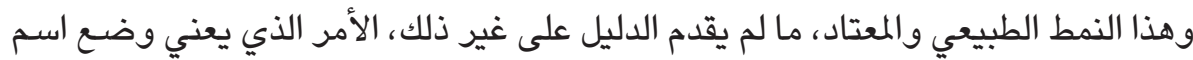

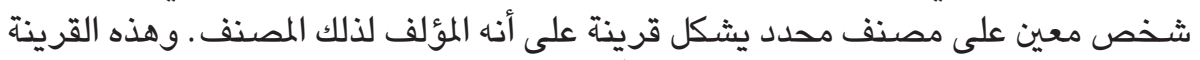

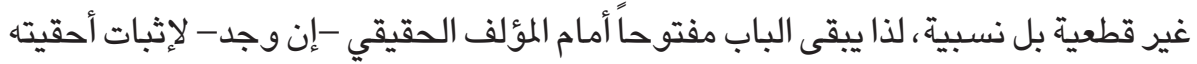
بالمصنف بكافة طرق الإثبات.

ومع ذلك، يجوز للمؤلف نشر مصنفه بلدون اسم أو ينشره باسم مستعار أو بأية

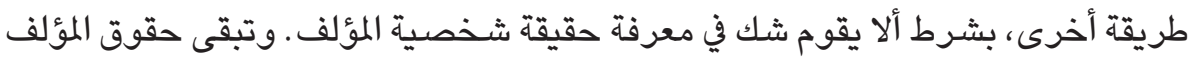

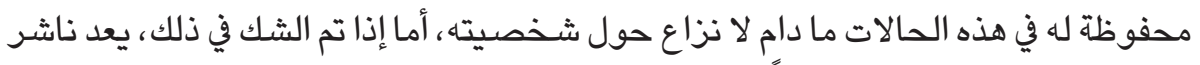

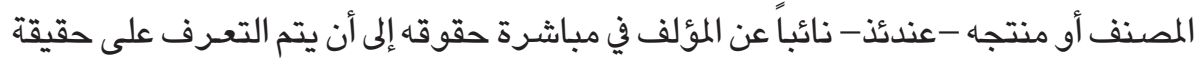
شخصية المؤلف.

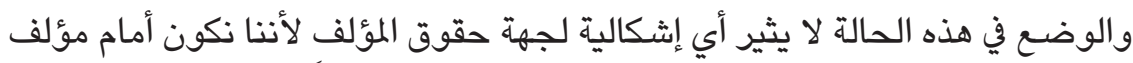

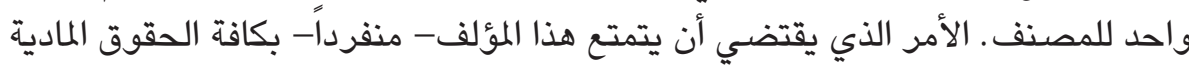

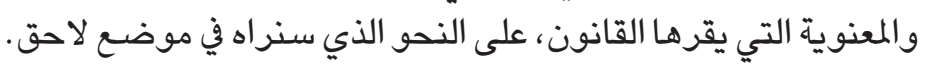

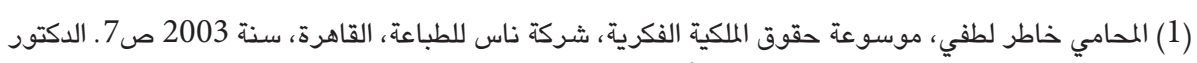

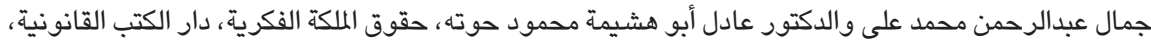

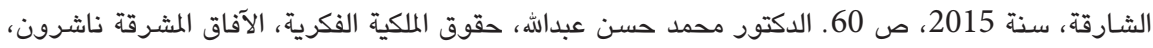

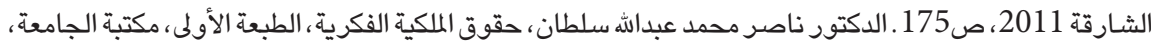

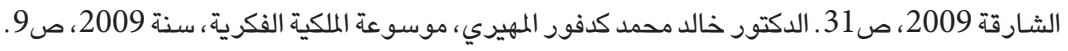




\section{2- حالة وضع المصنف بالاشتراك بين عدد من المؤلفين (المصنف المشترك):}

المصنف المشترك هو "المصنف الذي يساهم في إخراجه مؤلفان اثنان أو أكثر، ويمكن

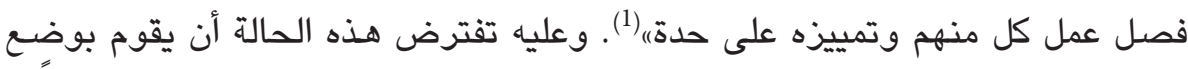

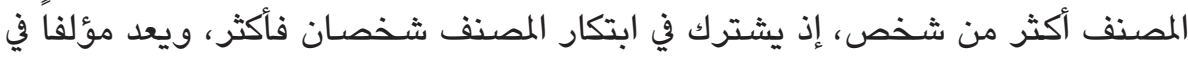

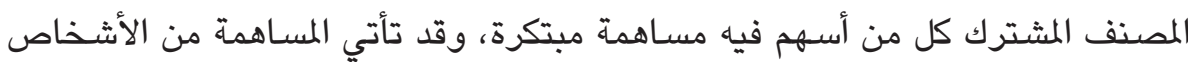

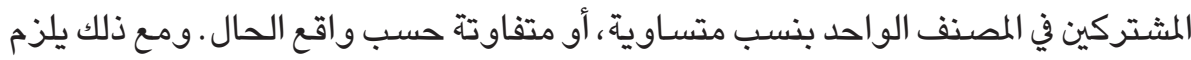

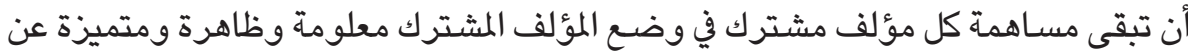

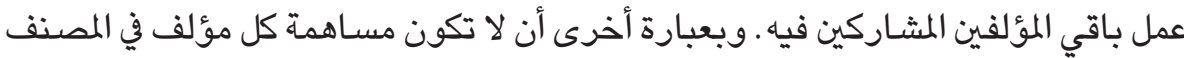

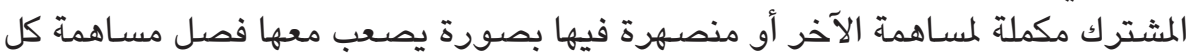

$$
\text { مؤلف على حدة. }
$$

فالوضـع في هذه الحالة، أنتا أمام مصنف شارك في تصنيفه أكثر من مؤلف، الأمر الذي

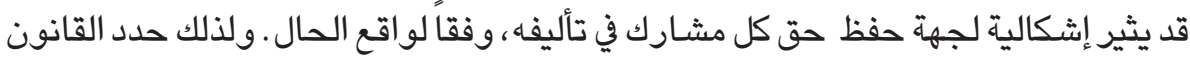

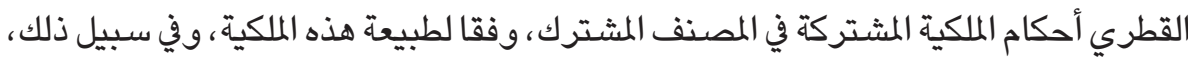

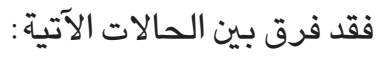

\section{الأولى- حالة المصنف الأدبي: - مالي}

تعالج هذه الحالة، المادة 33 من القانون القطري التي تنص على أنها : (إذا اشترك عدة

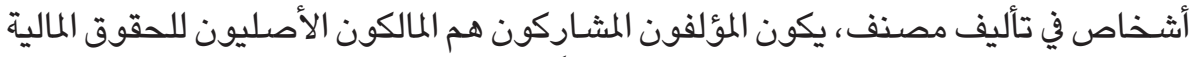

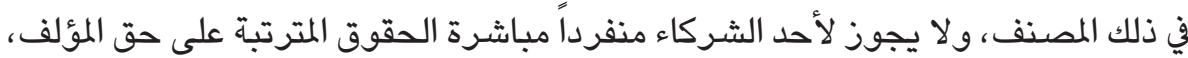

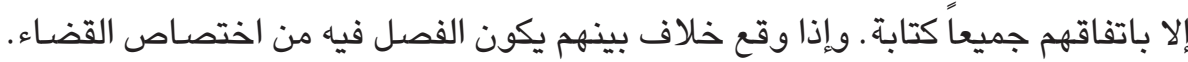

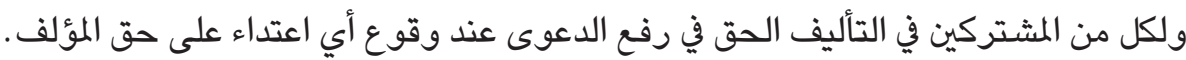

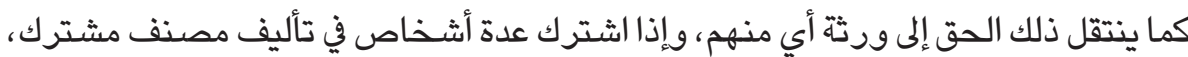

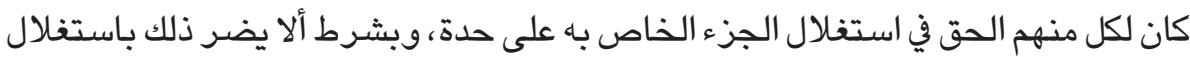

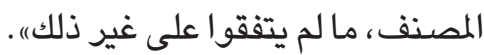

وعليه يكون المؤلفون المشاركون في المؤلف المشترك هم المالكون الأصليون للحقوق

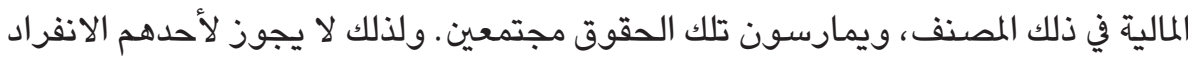

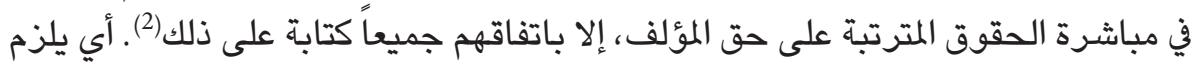
أخذ موافقتهم الخطية المسبقة على ممارسة حقوقهم على المقلى المصنف المشترك بصورة كاملة. 
ومع ذلك فقد أعطت المادة المذكورة لكل شريك في المصنف المشترك الحق في استغلال

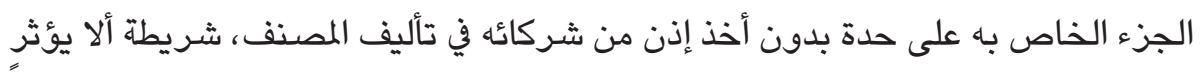

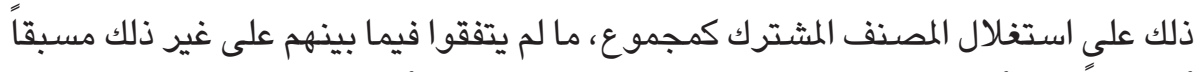

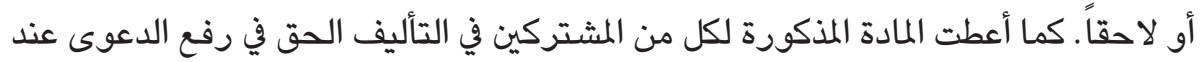

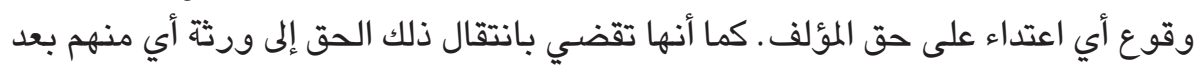
وفاته.

ويلاحظ أن المادة المذكورة قد اكتفت بالإشـارة إلى ملكية جميع "المؤلفين المشاركين

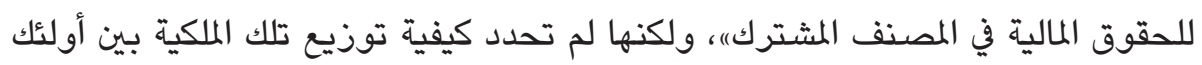

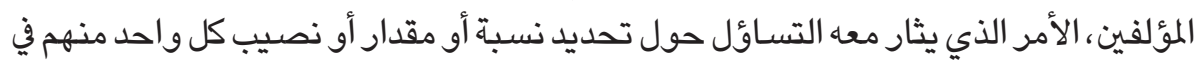

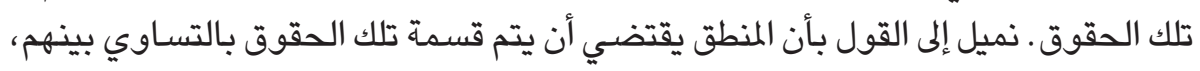

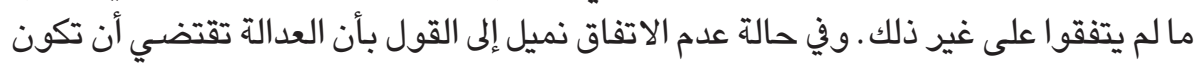

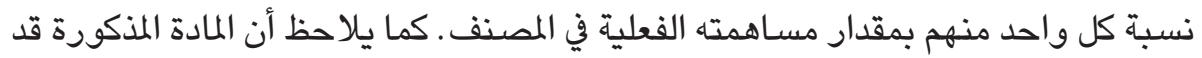

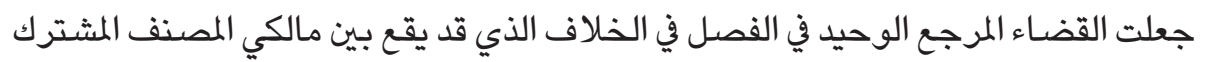

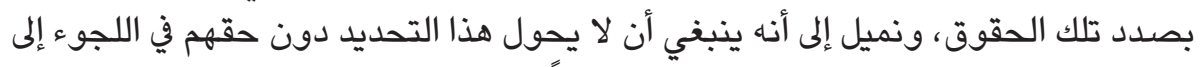
إحدى الوسائل البديلة لفض النزاع كالتحكيم مثلاً.

\section{الثانية- حالة المصنف الفني:}

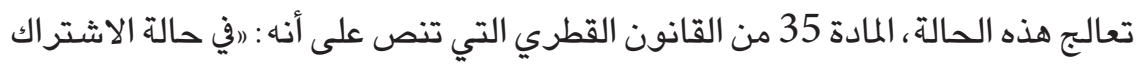

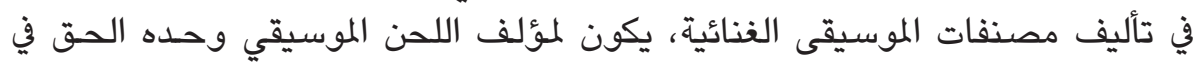

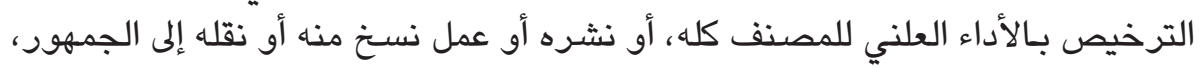

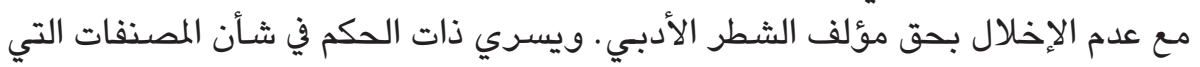

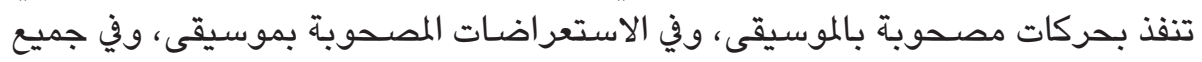

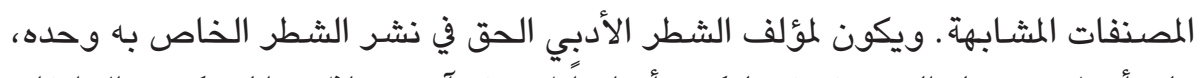

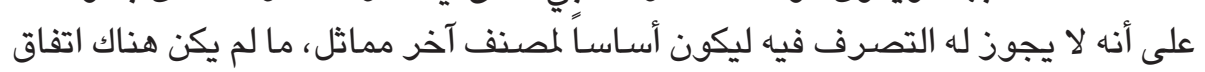
على خلاف ذلك).

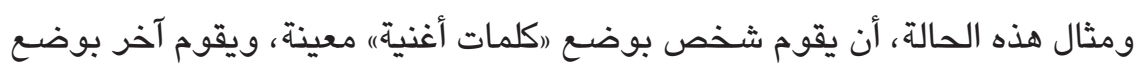

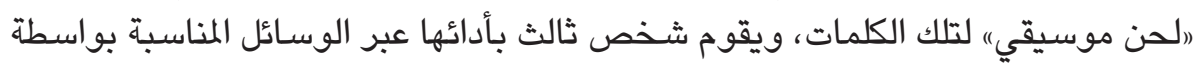

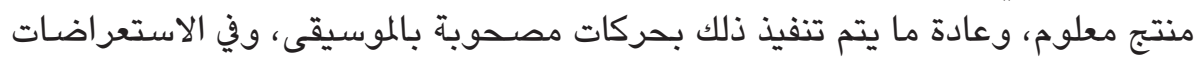
المصحوبة بموسيقى، وفي جميع المصنفات المشابهة ماتئ. 
وتعطي المادة المذكورة لمؤلف اللحن الموسيقي وحده الحق في الترخيص بالأداء العلني

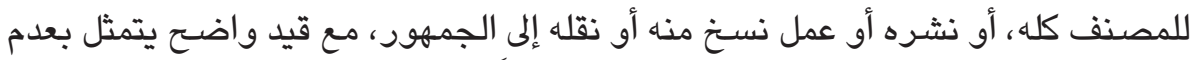

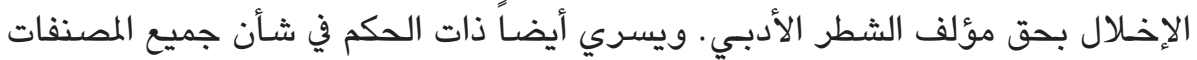

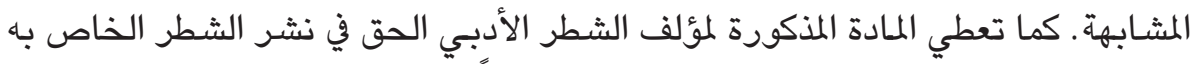

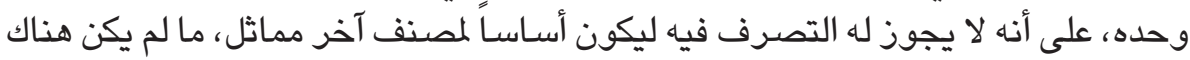
اتفاق على خلاف ذلك.

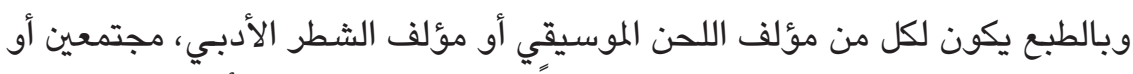

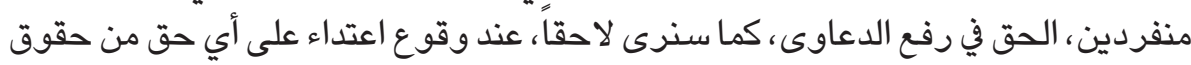

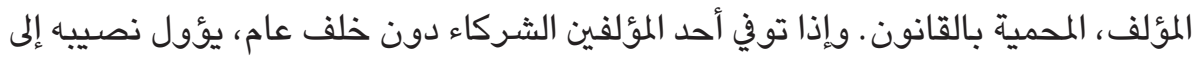

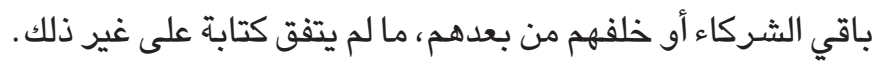

الثالثة- حالة المصنف السمعي البصري:

يتألف المصنف السمعي والبصري من سلسلة من الصور المترابطة التي تعطي انطباعاً

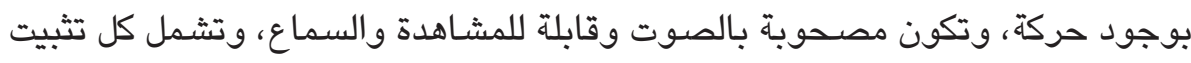

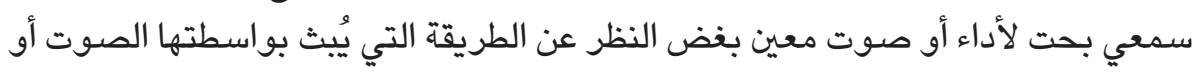

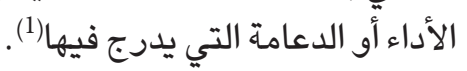

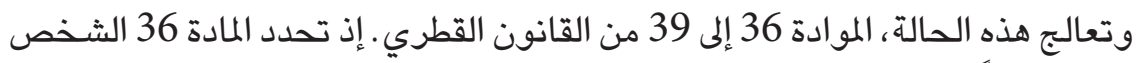
الذي يعد شريكاً في تأليف المصنف السمعي البصري المن بالآتي 1. مؤلف السيناريو، أو صاحب الفكرة المكتوية. 2. 2. 2. مؤلف الحوار.

3. من قام بتحوير المصنف الأدبي، بشكل يجعله ملائماً للمصنف السمعي البصري. 4. واضع الموسيقى، إذا قام بوضعها خصيصاً للمصنف السمعي البصري.

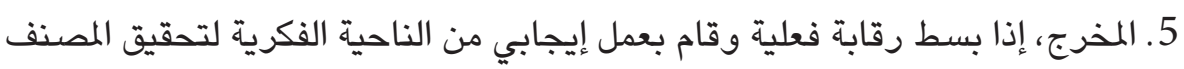
بكل أشكاله(2).

(1) ويستثنى من ذلك (التثبيت للصوت المصاحب للمصنف السمعي البصري)، المادة 1 من القانون القطري.

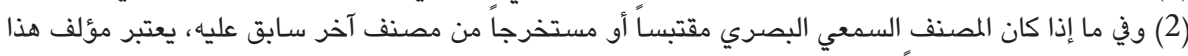

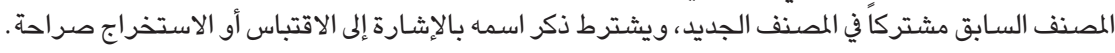


وتعالج المادة 37 حقوق الشركاء المذكورين في حال توقف أحدهم أو بعضهم عن إتمام الأعمال المكلفين بها، إذ تحدد حكم ذلك، كالآتي :

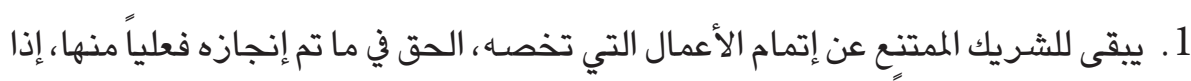

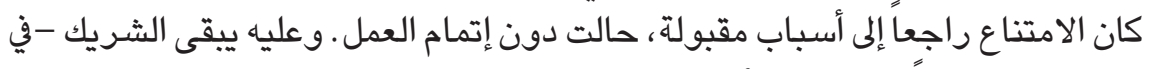

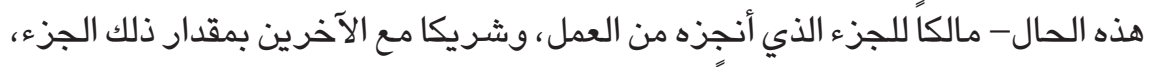

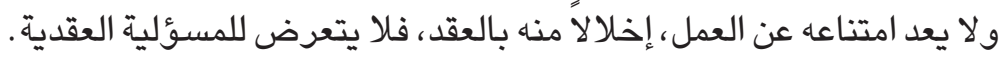

2. يحرم الشريك الممتنع عن إتمام الأعمال التي تخصها من الحق في ما تم إنجازه فعليا منها،

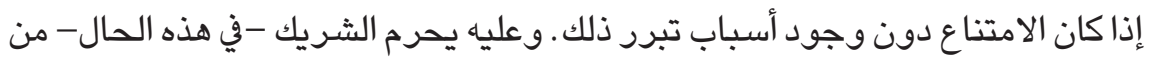

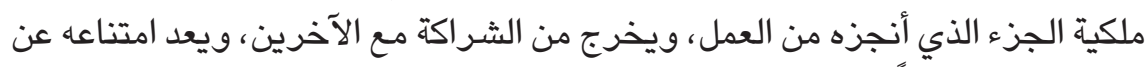
إتمام العمل، إخلالاً منه بالعقد، ويتعرض لـوض للمسؤولية العقدية.

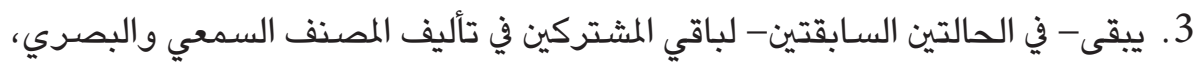

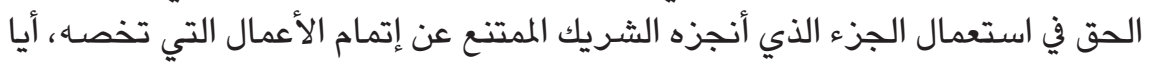

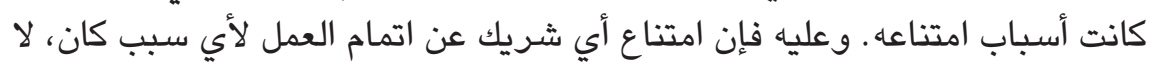

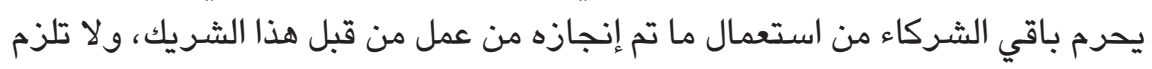

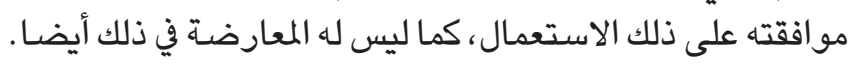

وأمـا المادة 38 فقد عالجت حالة رابتكار مصنف سمعي بصري من قبل مؤلف أدبي

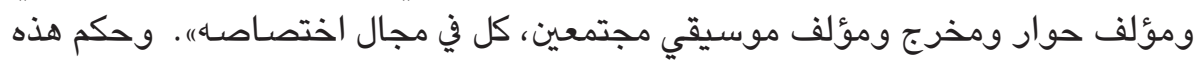

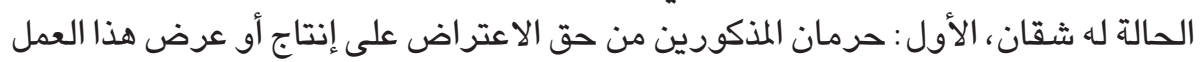

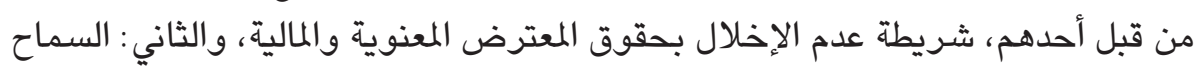

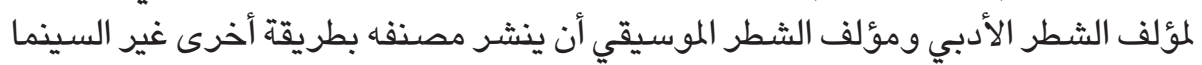
أو المسرح أو الإذاعة أو التلفزيون ، ما لم يتفق على غير المير ذلك.

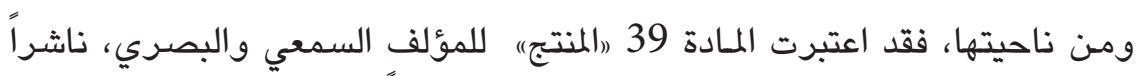

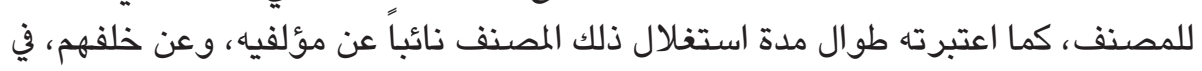

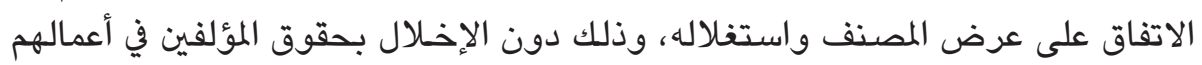
بطريقة أخرى، ما لم يكن هناك اتفاق على غير ذلك.

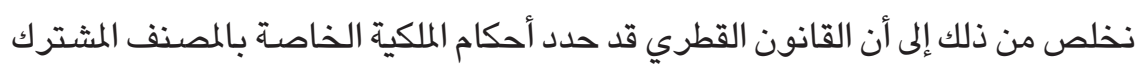

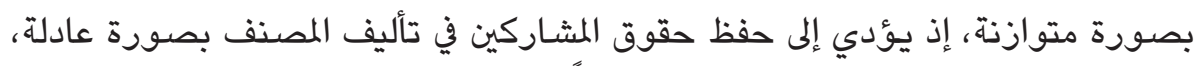

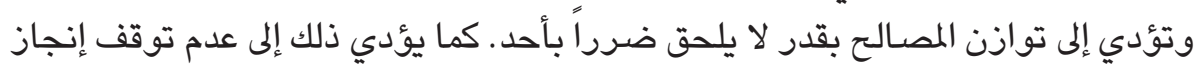
المصنف لامتتاع أحد الشركاء فيه عن إتمام العمل المخصص لأل له له من المؤلف المشترك. 


\section{3- حالة وضع المصنف من فريق من المؤلفين مجتمعين (المصنف الجماعي):}

المصنف الجماعي هو "المصنف الذي يساهم فيه عدة أشخاص طبيعيين، بمبادرة شخص طبيعي أو معنوي وتحت إثـرافه بحيث يستحيل فصل المهل عمل كل مساهم وتمييزه

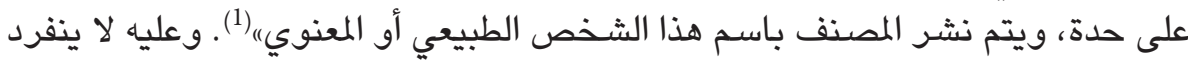

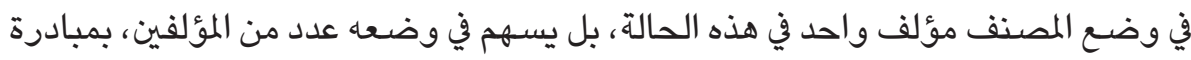

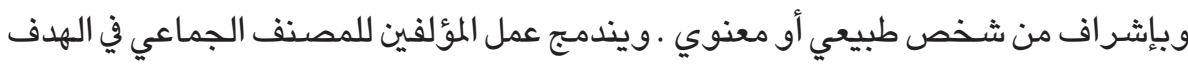

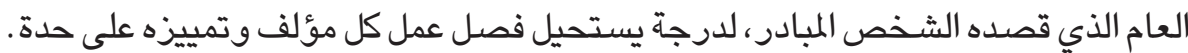

$$
\text { وعليه، حتى نكون أمام مصنف جماعي، يلزم تحقق الآتي : }
$$

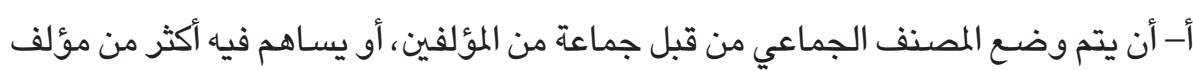

$$
\text { واحد. }
$$

ب- أن تكون مساهمة كل مؤلف مكملة لمساهمة الآخر، وتنصهر معها بصورة يصعب

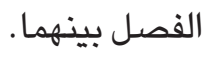

ت- أن يتم المصنف الجماعي بتوجيه شخص طبيعي أو معنوي، يتكلف بنشره باسمه وتحت إشـرافه.

أن يتم ذلك بموجب عقد مكتوب يحدد حقوق والتزامات الطرفين بوضوح تام .

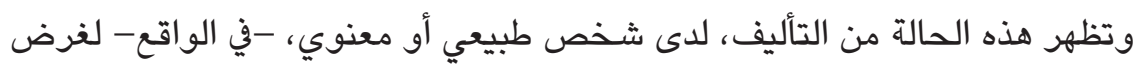

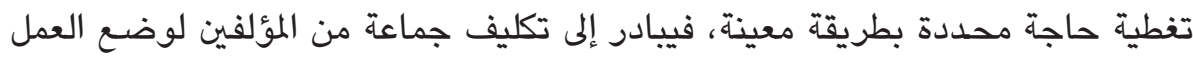

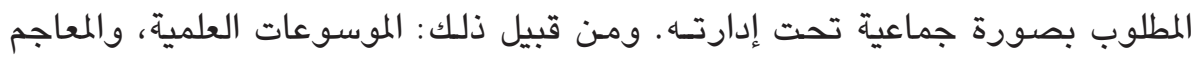

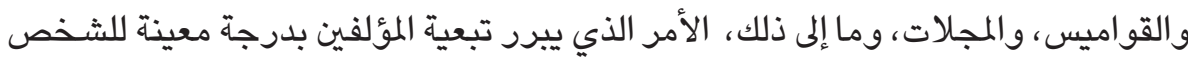

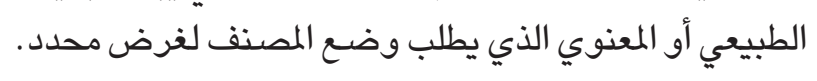

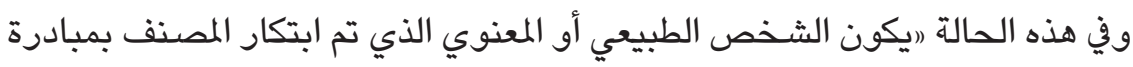

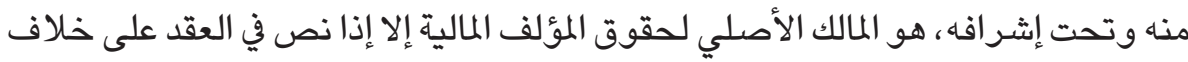

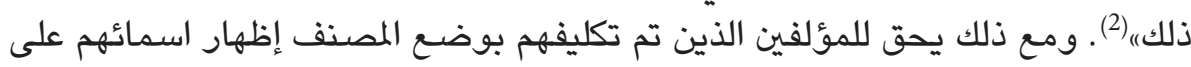

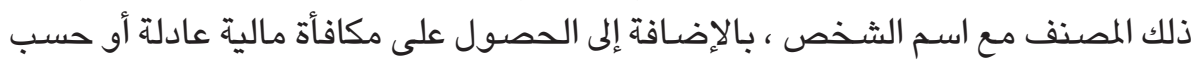
الاتفاق. 


\section{4- حالة وضع مصنف مشتق من مصنفات سابقة (المصنف المشتق أو المركب)}

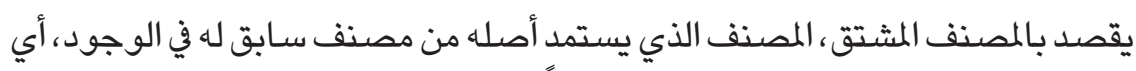

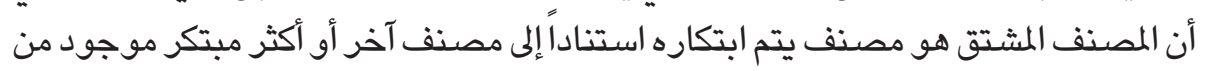

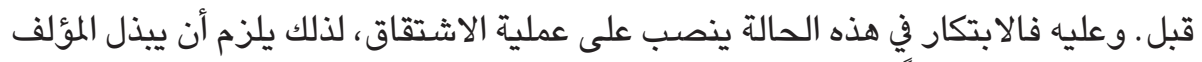

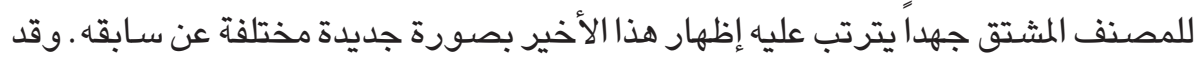

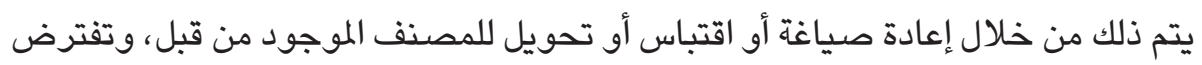

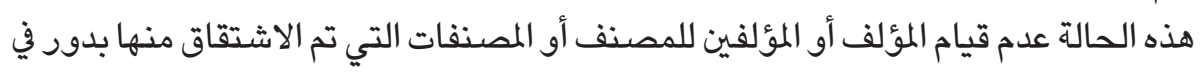
المصنف المشتق أو المركب.

\section{ومن قبيل المصنفات المشتقة أو المركبة الآتي (1):}

أ - مصنفات الترجمة والتخيص والتعديل والشرح و غيرها من التحويرات.

ب- مجموعة الموضوعات والمختارات إذا كانت مبتكرة من حيث انتقاء المواد أو ترتيبها. ت- قواعد البيانات، إذا ما كانت هذه المجموعات مبتكرة بسبب ترتييها، أو اختيار محتوياتها.

ث- مجموعة المصنفات والتعبيرات الفلوكلورية، إذا ما كانت هذه المجموعات مبتكرة

$$
\text { بسبب ترتيبها أو اختيار محتوياتها. }
$$

ويعد الشخص الذي يضع المصنف المشتق أو المركب من مصنفات سابقة له، مؤلفاً

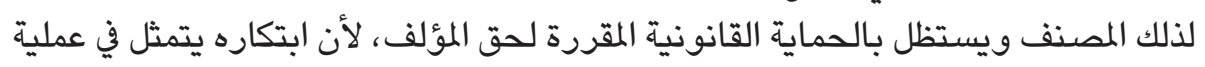

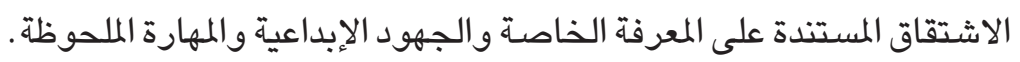

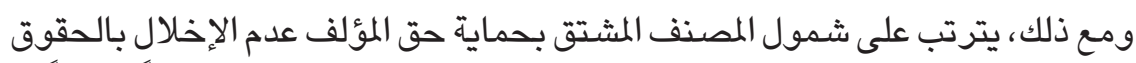

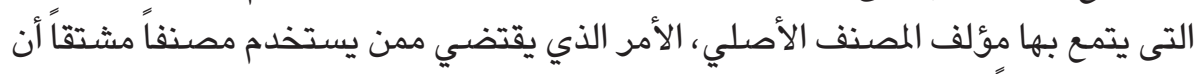

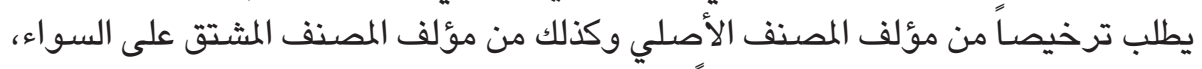

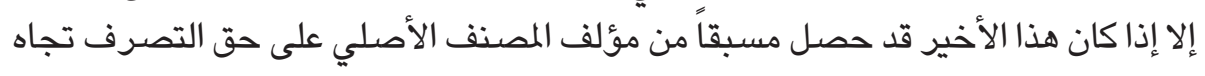

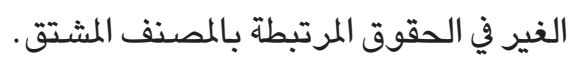

وعليه يلزمٍ - في كل الأحوال- الأخذ في الاعتبار حقوق من يضـع المُصنف أويشـارك فيه

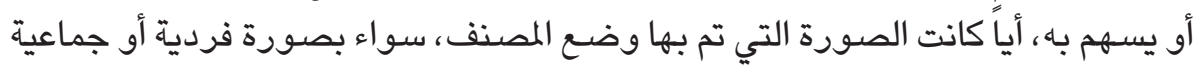
أو مشتركة أو مشتقة، و ولك بغرض الت حفظ حقوق كل صاحب حق فيه أو عليه.

(1) (1) - (المادة 3 من القانون القطري. 


\section{المطلب الثاني \\ شروط حماية حقوق المؤلف}

يلزِم أن يتوفر في المصنف شروط موضوعية، كشرط الابتكار الذي يضفي عليه طابعاً

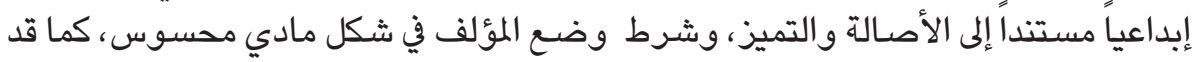

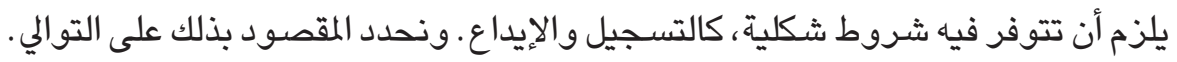

\section{الفرع الأول}

\section{الشروط الموضوعية}

تتمثل هذه الشروط في شرط الابتكار، وشرط الإظهار ـ وبيان ذلك:

1 شرط الابتكار: - n

يقصد بشرط الابتكار -على وجه الإطلاق- أن يظهر المؤلف مصنفه بذاتية خاصة

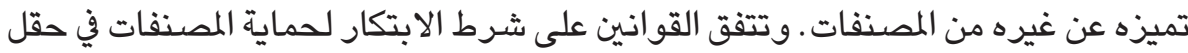

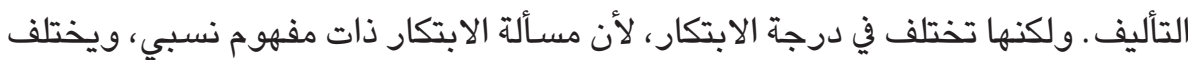

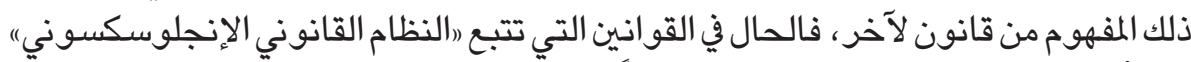

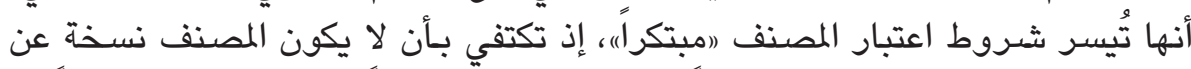

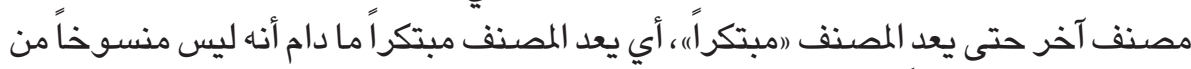

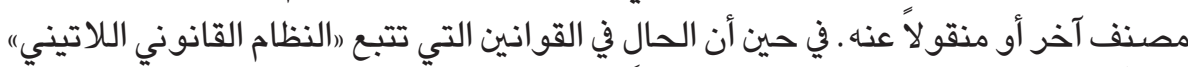

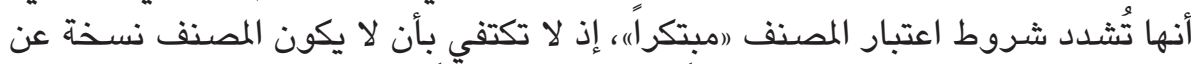

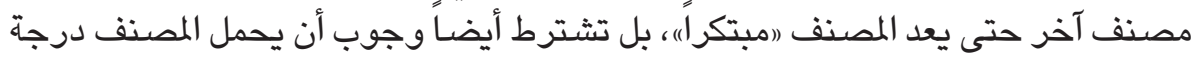

$$
\text { من الإبداع تظهر شخصية المؤلف في مصنفه (1). }
$$

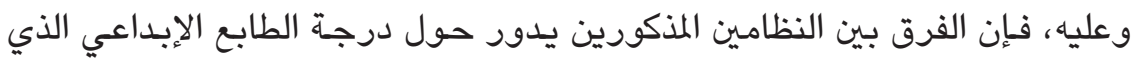

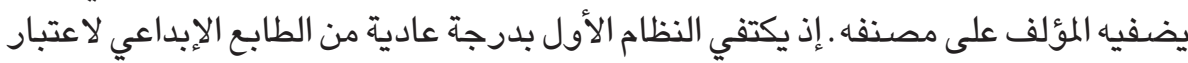

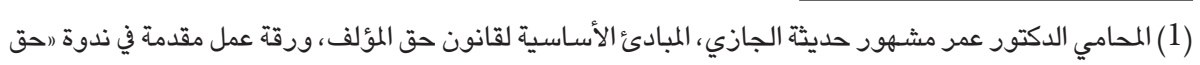

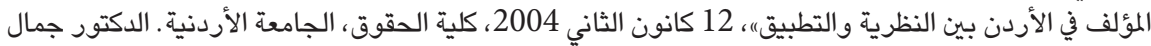

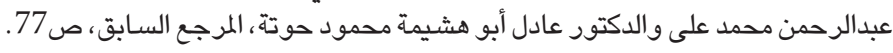




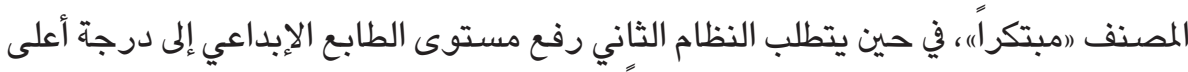
من الدرجة العادية لاعتبار المصنف (مبتكراً)(1).

وفي هذا الصدد، نجد أن القانون القطري قد اشترط أن تكون المصنفات الأدبية أو الفنية

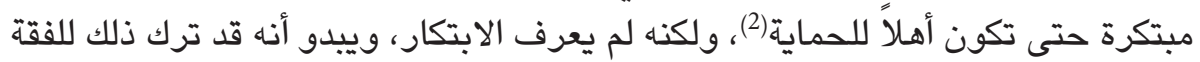

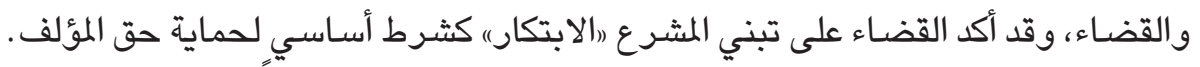

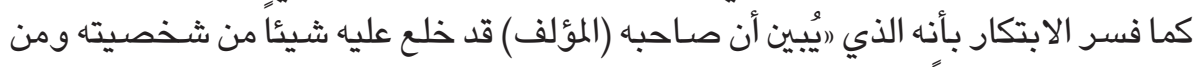

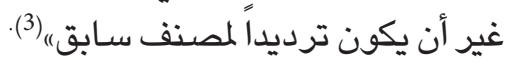

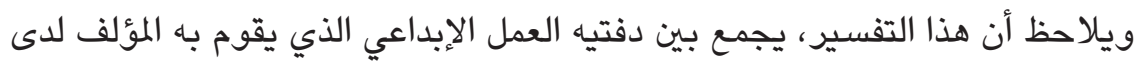

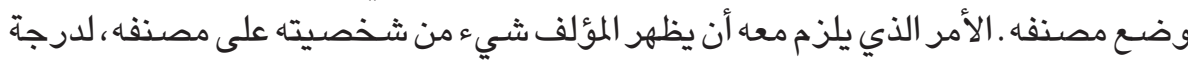

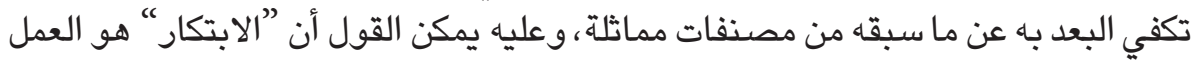

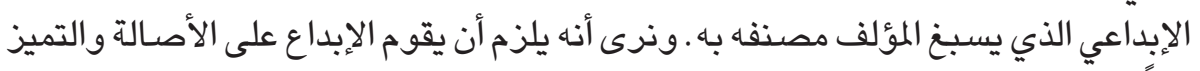

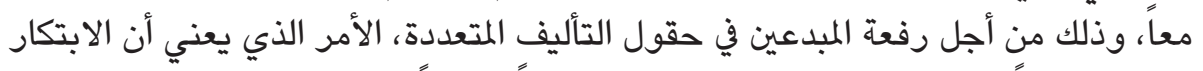

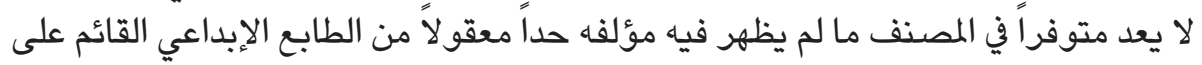

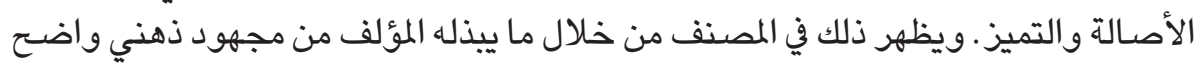

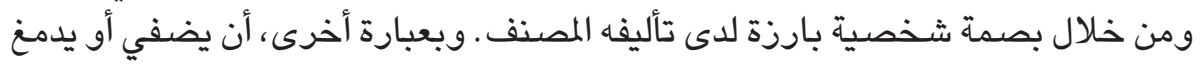

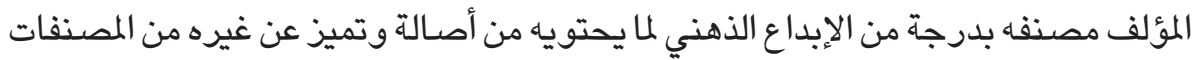

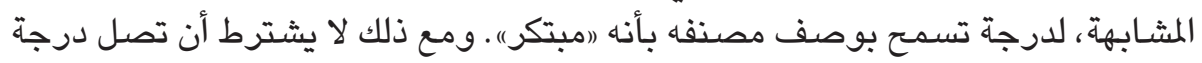

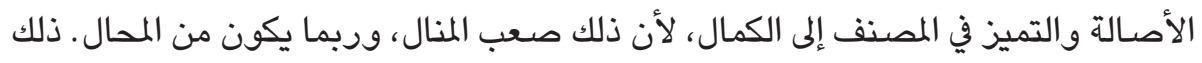

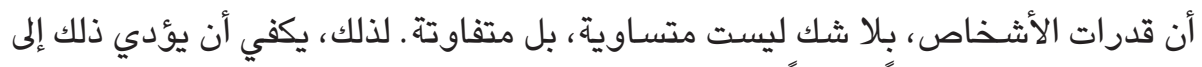

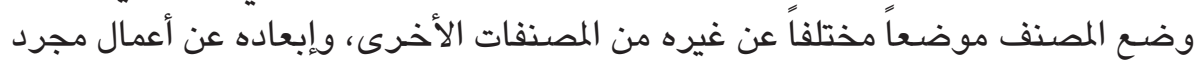
النقل والترديد والتكرار. وعليه، يعد مصنفاً مبتكراً كل مصنف يحتوي على قدر معقول من الإبـاع الأصيل

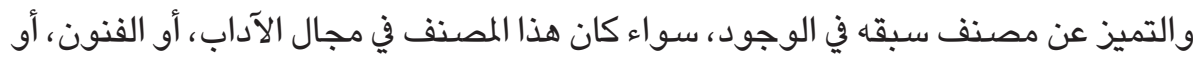

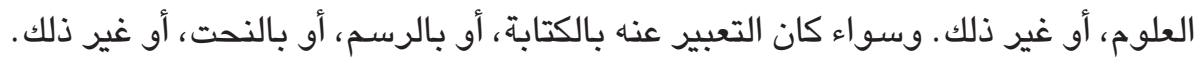

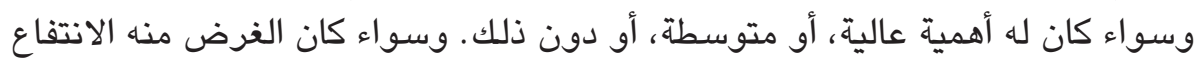
الشخصي أو الاستثمار ، أو غير ذلك. اهلك أهن

$$
\begin{aligned}
& \text { (1) الدكتور عبدالرشيد مأمون والدكتور محمد سامي عبد الصادق، المرجع السابق ، ص100. }
\end{aligned}
$$

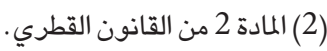

$$
\begin{aligned}
& \text { (3) طعن رقم } 225 \text { لسنة } 2011 \text { تمييز- جلسة } 13 \text { من مارس سنة 2012م. }
\end{aligned}
$$


وتعد مسألة وجود الابتكار في المصنف من عدمه، مسألة واقعية وموضوعية في آن

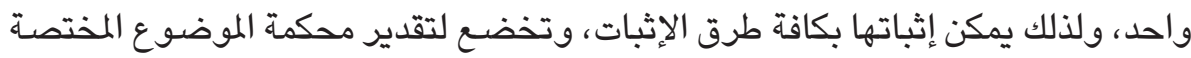

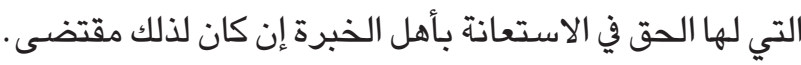

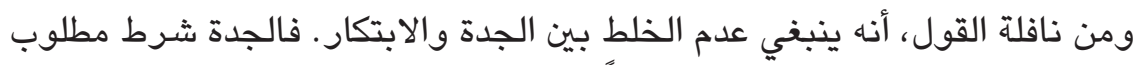

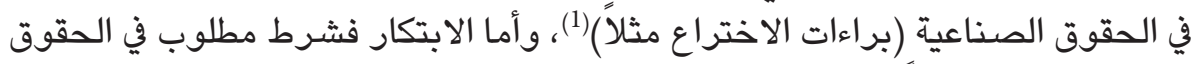

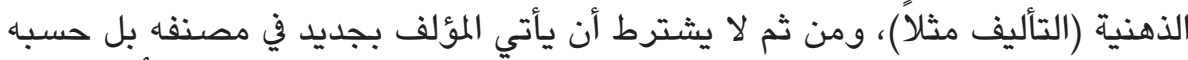

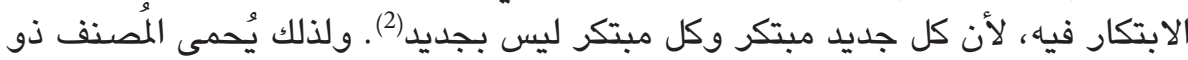

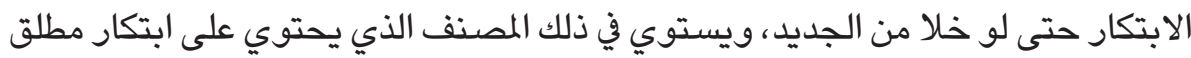
أو ابتكار نسبي.

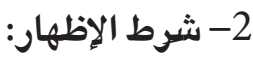

لا تكفي صفة الابتكار، حتى تُحمى حقوق المؤلف، بل يلزم أيضاً، بعد فراغ المؤلف

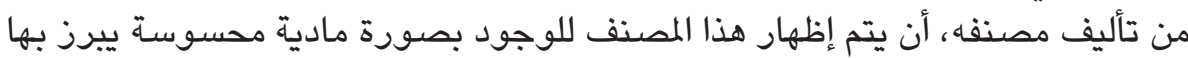

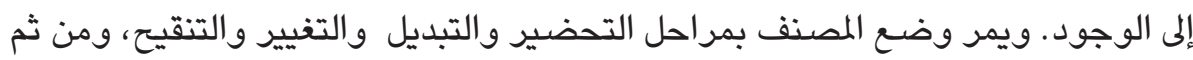

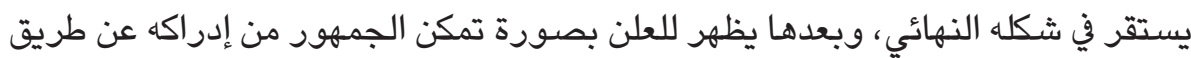

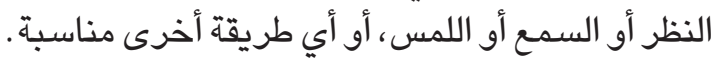
وينطبق هذا الشرط على المصنف أياً كان مجاله أدبياً كالكتب ونحو ذلك، أو أو علمياً

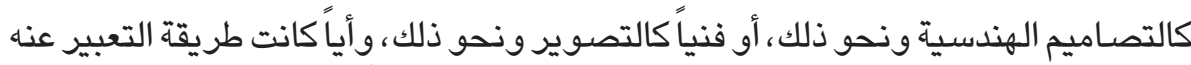

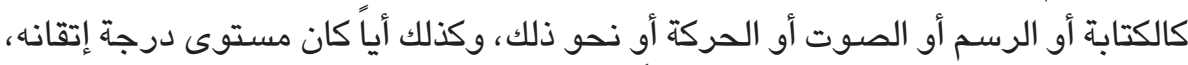

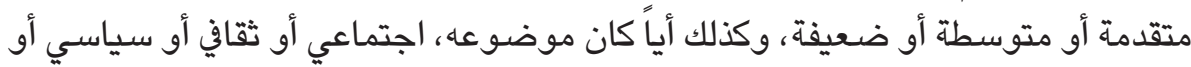
نحو ذلك.

(1) الدكتور صلاح زين الدين، شرح قانون براءات الاختراع القطري، دار وائل للنشر والتوزيع، عمان الطبعة الأولى

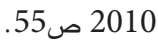
(2) الدكتور محمد حسام محمود لطفي ، المرجع السـابق، ص25. 


\section{الفرع الثاني}

\section{الشروط الشكلية}

حدد القانون القطري شروطاً شكليةً لغرض إيداع المصنفات وتداولها في دولة قطر.

$$
\text { 1 ونعرض بإيجاز لهذه الشروط على التوالي: }
$$

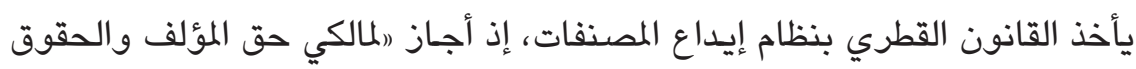

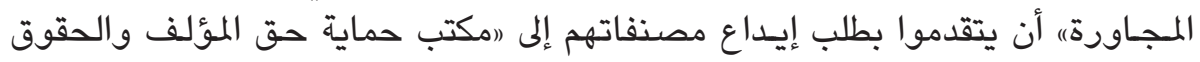

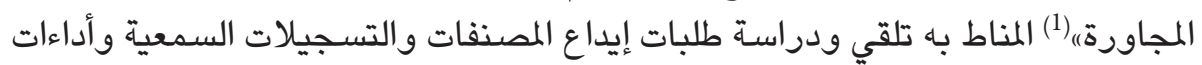

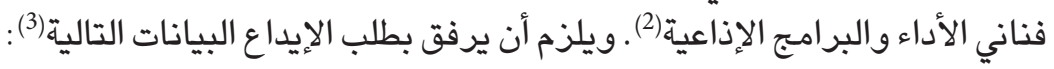

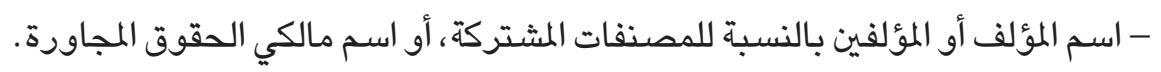
- موضوع المصنف أو موضوع الحق المجاور . - عدد نسختين من المصنف أو من العمل موضوعوع الحق المجاور . - بيان شـامل بمواصفات المصنف أو العمل موضوع الحق المجاور.

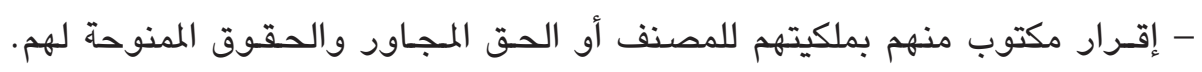

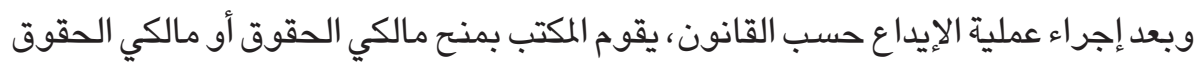

(1) وقد جاء إنشـاء هذا المكتب إعمالاً لنص المادة 44 من القانون القطري. ويتبع هذا المكتب إدارة الشؤون التجارية في وزارة

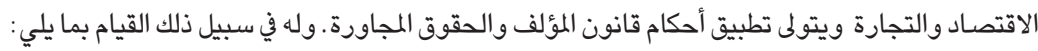

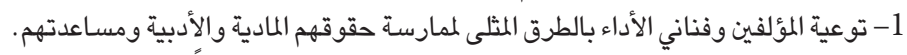

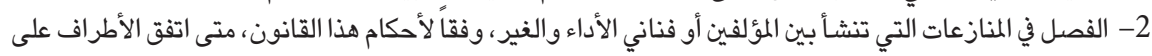
ذلك. 3- دراسة ومتابعة ما يثار من قضايا تتعلق بحق المؤلف والحقوق المجاورة على المستوى المحلي والعربي والدولي وتقديم الاقتراحات أو التوصيات في هذار منا الشأن. 4- دراسة طلبات إيداع المصنفات والتسجيلات التقات السمعية وأداءات فناني الأداء والبرامج الإذاعية، وذلك وفقاً لأحكام هذا القانون.

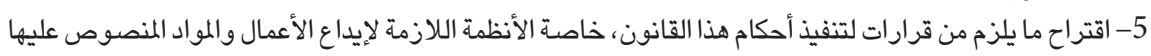

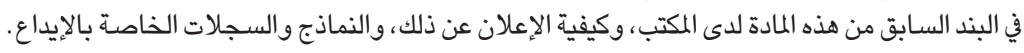

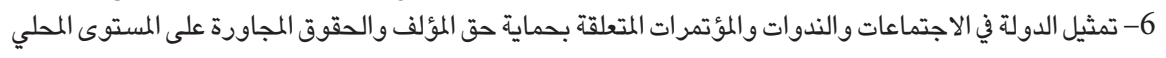
والعربي والدولي.

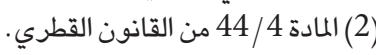
(3) (3) (المادة 45 من القانون القطري. 


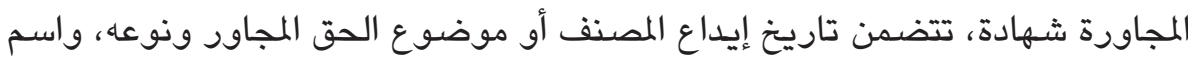

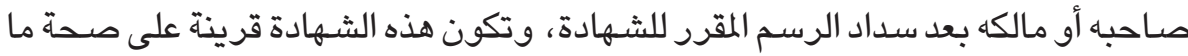

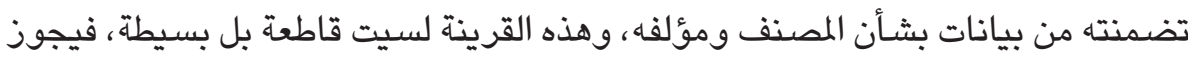
للغير إثبات عكسـها(1).

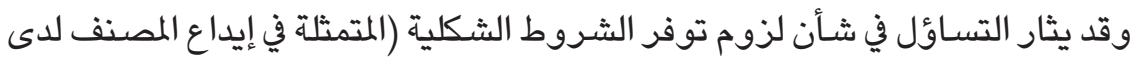

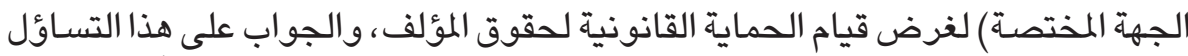

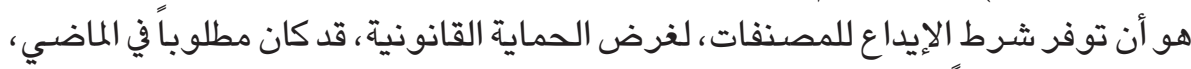

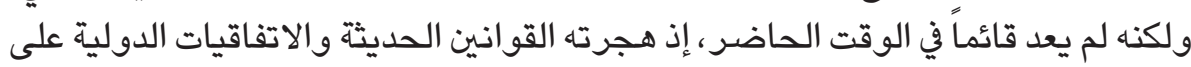

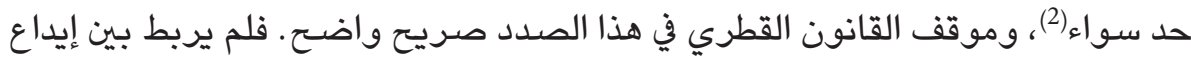

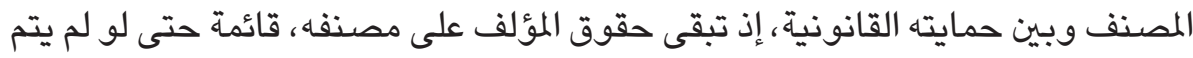
إيداعه (3).

ومع ذلك لا تخلو سجلات الإيداع من فائدة، إذ تعد مرجعاً مهماً لبيانات المصنفات

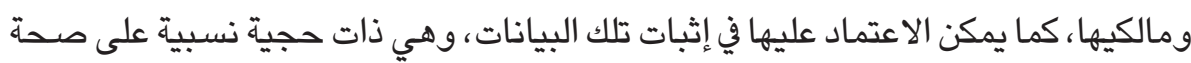

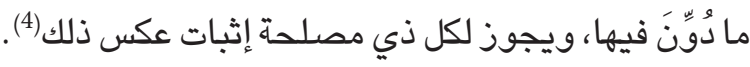

ويفرق البعض بين شرط تسجيل المصنفات، وبين نظام إيداعها لدى المكتبات الوطنية

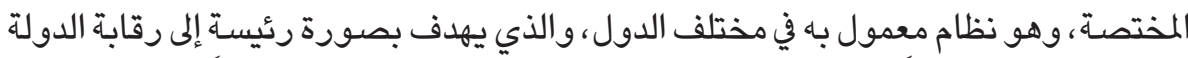

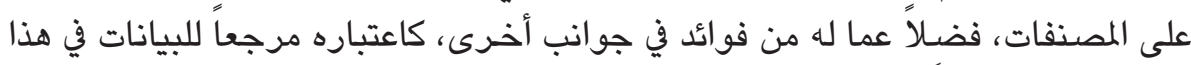

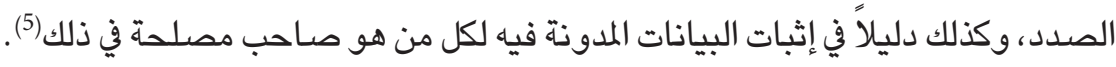
ومن الجدير بالذكر أن القانون القطري يعطي "الموظفي مكتب حماية حق المؤلف والحقوق

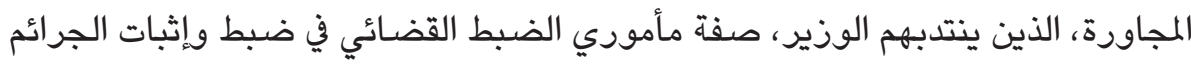

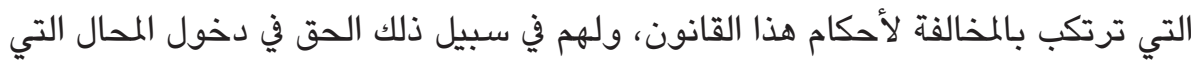

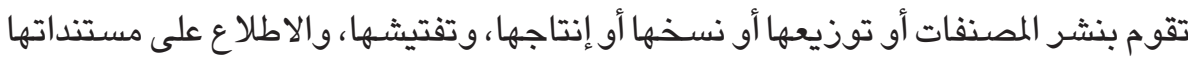

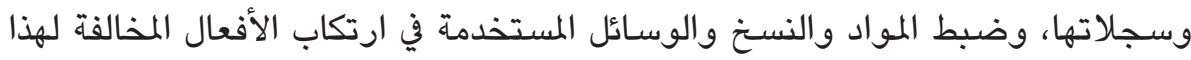

(1) (1) المادة 46 من القانون القطري. (2) وبخاصة بعد اتفاقية برن واتفاق تربس. الدكتور حسن جميعي، مدخل إلى حقوق المؤلف والحقوق المجاورة،

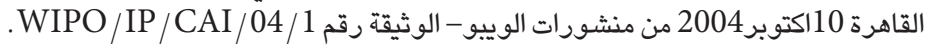
(3) (3) المادة 45 من القانون القطري. (5) (3) المادة 46 من المادة 46 من القانون القطرن القطري. (5) الدكتور عبدالرشيد مأمون والدكتور محمد سامي عبدالصـادق، المرجع السابق، 105. 
القانون)|(1). وليس من شك في أن هذا الأمر يعزز بقوة حماية حقوق المؤلف والحقوق المجاورة

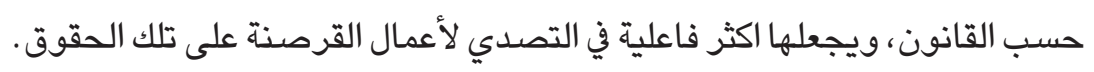

$$
\text { 2- شروط تداول المصنقات: }
$$

يأخذ القانون القطري بنظام الرقابة على المصنفات قبل تداولها، وذلك في سبيل تسهيل

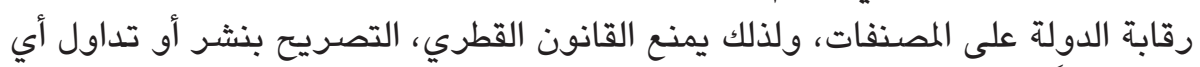
مصنف أياً كان نوعه، ما لم يرفق به المهات ما يلي (2) :

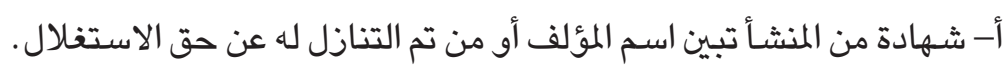

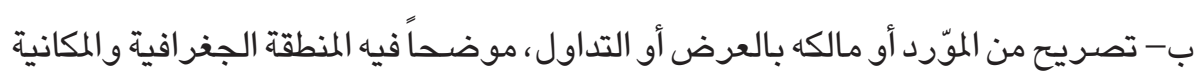
التي صرح بالعرض أو التداول في نطاقها.

ت- وليس من شك في أن هذه الشروط تسهم بفاعلية رقابة الدولة على المصنفات، فضعلاً

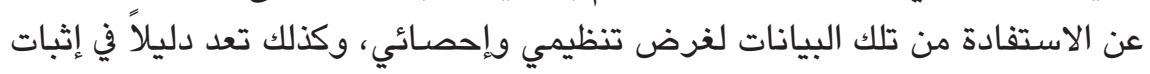

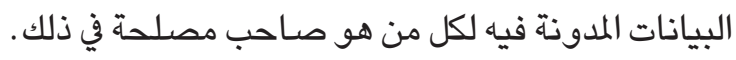

\section{المطلب الثالث}

نطاق الحمايـة القانونية للمصنفات

نبين في هذا المطلب : المصنفات المحمية والمصنفات غير المحمية على التوالي:

\section{الفرع الأول \\ المصنفات المحمية}

يقصد بالمصنفات المحمية : المصنفات المبتكرة التي تنص القوانيين على حمايتها. وقد

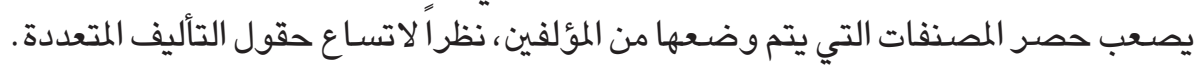

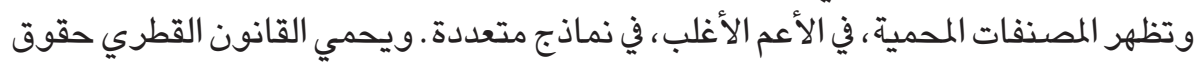

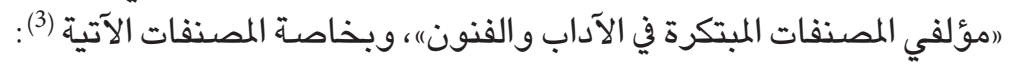

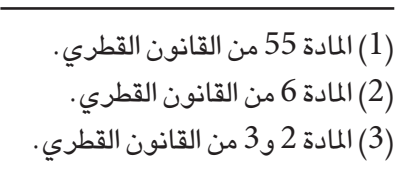




\section{1- الكتب والكتيبات وغيرها من المواد المكتوبية:}

يتسـع نطاق هذه المصنفات لتشمل المؤلفات المكتوبة في المجالات الأدبية ، أو الفنية. ومن

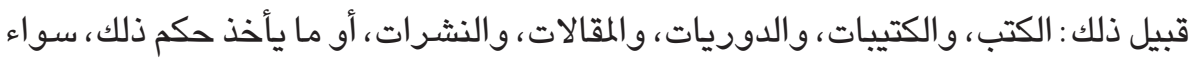

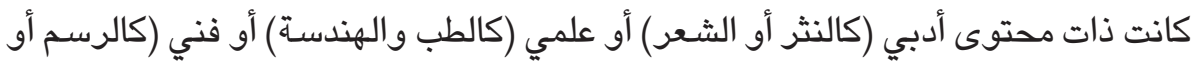
النحت) أو غير ذلك. ولا يخفى أن هذه المصنفات تشترك في إطار واحد، يتمثل في أن وسيلة التعبير عن أيٍِّ منها هو الكتابة ـ كما يمكن وصف هذه هذه المصنفات بالتقليدية المألوفة، لكونها

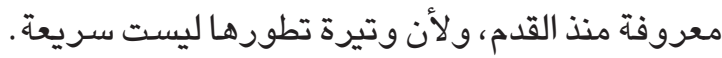

2- المصنفات التي تلقى شفاهة:

يشمل نطاق هذه المصنفات: المحاضـرات التي تلقى شفاهـة في دور العلم والمعرفة كالجامعات والمعاهد والمؤتمرات لغرض تزويد المتلقين بالتعليم النافع في العلوم المتعددة. وكذلك الخطب والمواعظ التي تلقى في دور العبادة والأماكن العامة لحث الناس على اتباع الفضـائل واجتناب الرذائل، وأي مصنفات أخرى لها طبيعة مماثلة كالأشعار والأناشيد. ويلاحظ أنه يتم التعبير عن هذه المصنفات غالباً، بصورة شفوية أو سمعية. وممع ذلك لا يوجد ما يمنع أن تكون بصورة مكتوبة أيضًا؛ ذلك لأن المصنف المكتوب لا ينقلب مصنفاً

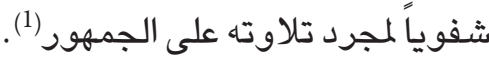
ومن نافلة القول أن المصنفات المذكورة (المكتوبة وغير المكتوبة) تخاطب عقل الجمهور المعني بالفكرة أو الأفكار التي تحتويها تلك المصنفات، ولذلك تخضـع إلى رقابة -سـابقة أو أو لاحقة- مبررة من الجهات ذات الاختصـاص المخولة من الدولة، وذلك لغرض عدم المس إلى

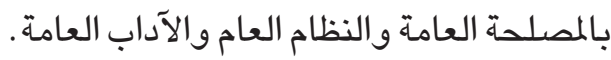

\section{3- المؤلفات المسرحية والمسرحيات الموسيقية:}

يدخل في نطاق هذه المصنفات جميع المصنفات التي يتم التعبير عنها عن طريق التمثيل.

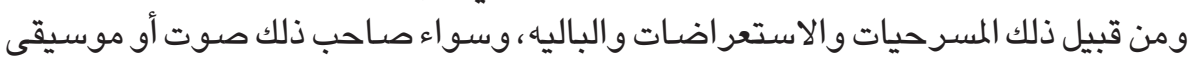
أو لم يصـاحبها. و لا يدخل في هذا النوع من المصنفات، الأفلام أو المسلسـلات لأن هذه الأخيرة تعد من المصنفات السمعية البصرية.

\section{4- المصنقات الموسيقية، سواء أكانت مصحوبة بكلمات أم بدونها:}

تظهر المصنفات الموسيقية المصحوبة أو غير المصحوبة بكلمات في صورة الأناشيد والتواشيح والأعمال الأوبرالية والموسيقى التصويرية والأغاني.

(1) الدكتور مختار القاضي، حقوق المؤلف، الكتاب الأول، مكتبة الإنجلو المصرية القاهرة، سنة 1958، ص18. 
5- مصنفات تصميم الحركات الإيقاعية والتمثيل الإيمائي:

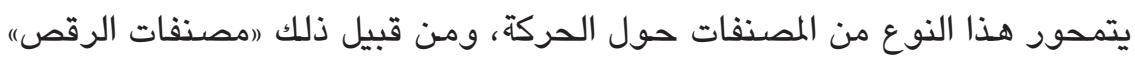

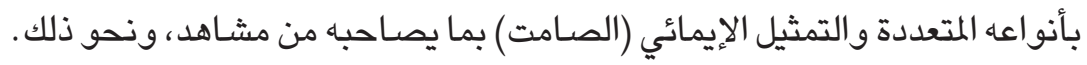
6- المصنفات السمعية والبصرية:

يقصد بالمصنفات السمعية والبصرية، المصنفات التي تتألف مـن سلسلة من

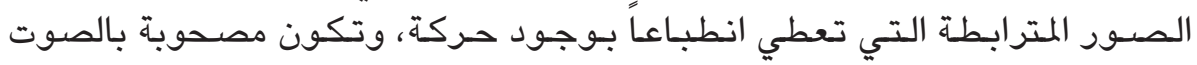

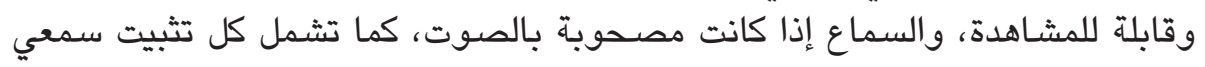

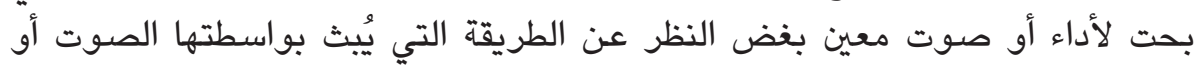

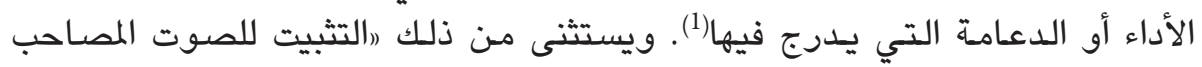

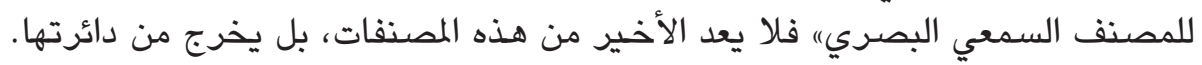

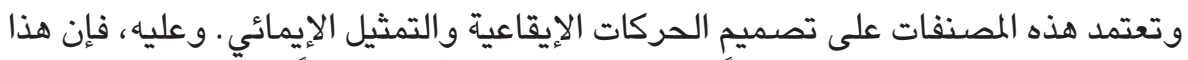

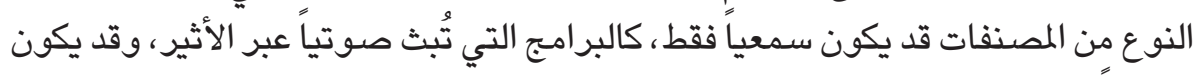

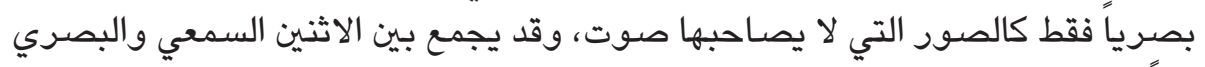

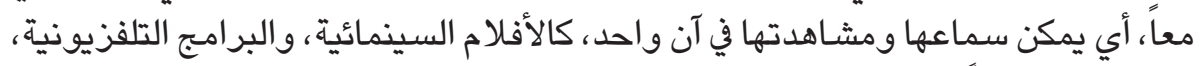
المعدة للبث صوتاً وصورة في الوقت ذاتهاته

\section{7- المصنفات الفوتوغرافية وما يماثلها:}

ينصرف هذا النوع من المصنفات إلى صور أشياء حقيقية يتم التقاطها بواسطة آله تقنية.

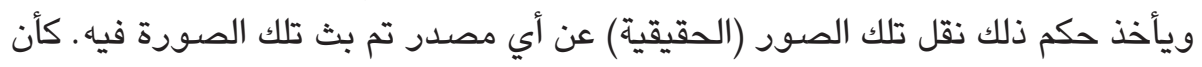

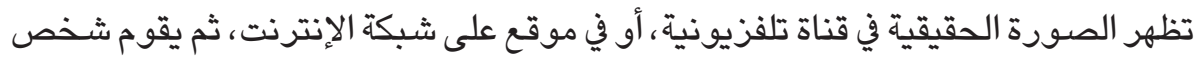
بالتقاطها.

\section{8-مصنفات الفنون التطبيقية، سواء أكانت حرفية يدوية أم صناعية:}

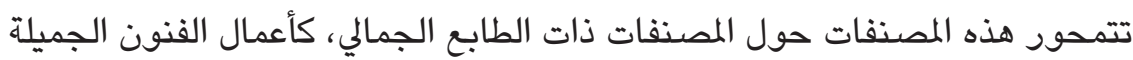

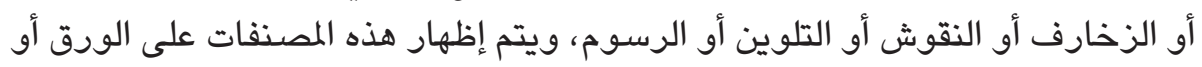

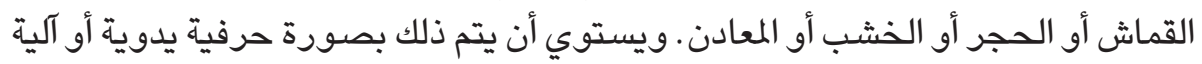

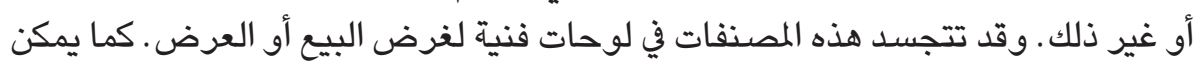

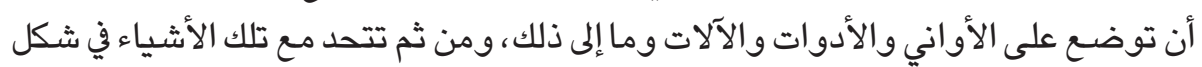
مادي مجسـم.

(1) (1) - (المادة 1 من القانون القطري. 
9- مصنفات الرسم والتصوير بالخطوط والألوان والعمارة والنحت والفنون الزخرفية

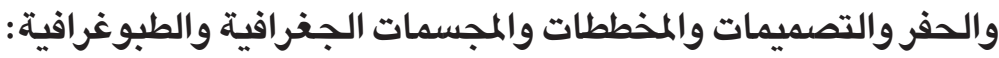

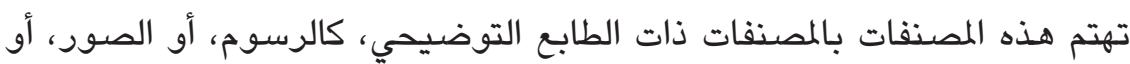

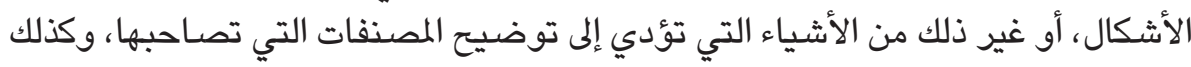

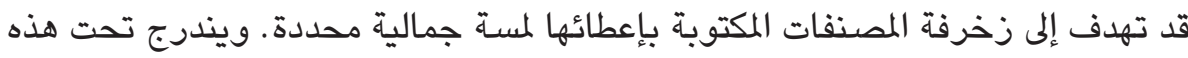

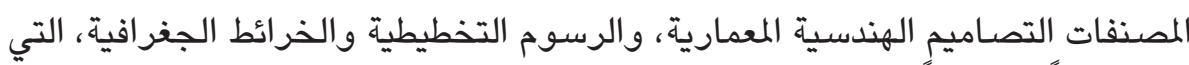

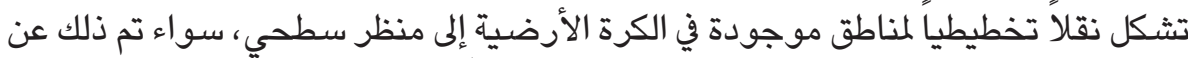

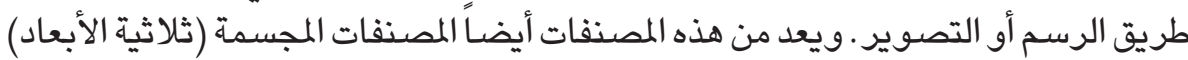

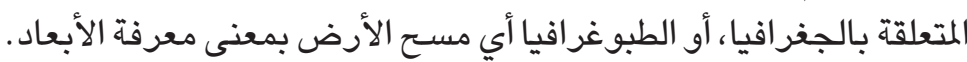
ويبدو أن الجامع بين هذه المصنفات أنها أعمال هندسية مبتكرة تعتمد على فنون الرسم

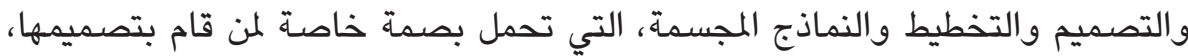
سواء تم ذلك بصورة فردية أو بصورة جماعية (1).

$$
\text { 10- برامج الحاسب الآلي: }
$$

المقصود ببرامج الحاسب (تعليمات معلومة يتم قراءتها تقنياً لأداء وظيفة محددة).

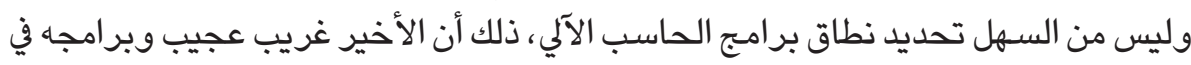

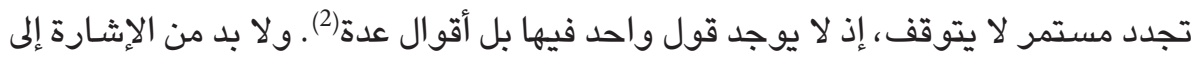

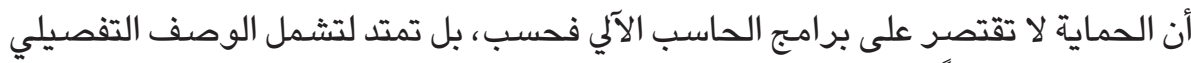

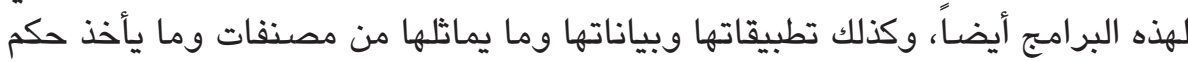

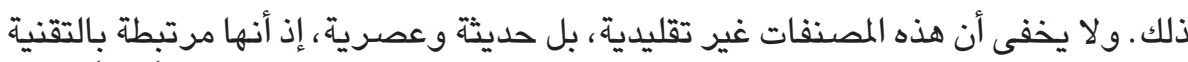

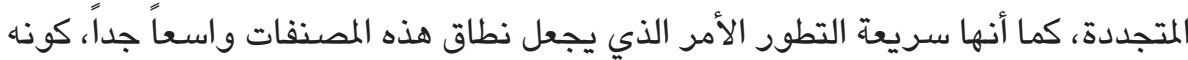

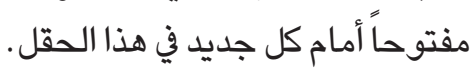

11 مصنفات الترجمة والتلخيص والتعديل والشرح وغيرها من التحويرات: يقصد بهذه المصنفات، المصنفات المشتقة أو المركبة التي سبق الحديث عنها، وتظهر

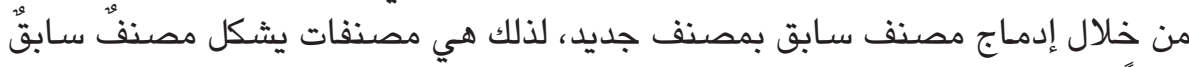

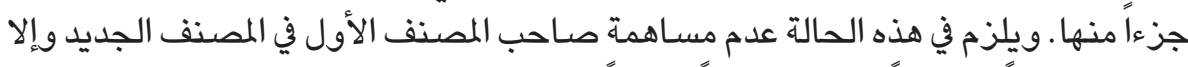
أصبح مصنفاً مشتركاً وليس مصنفاً مشتقاً. ومن قبيل ذلك الكالك : رواية أدبية يشتق منها فيلم

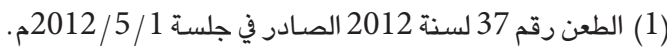

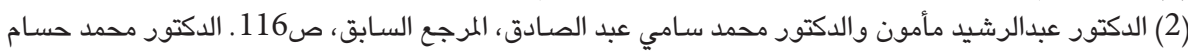

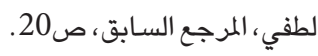




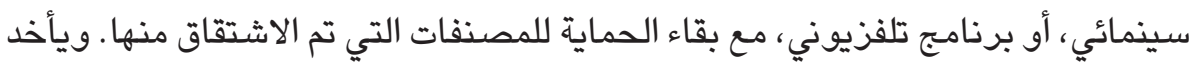

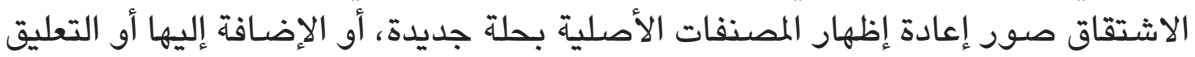

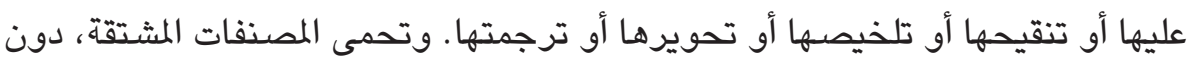
الإخلال بالحماية المقررة للمصنفات التي اشتقت منها.

12- مجموعة الموضوعات والمختارات إذا كانت مبتكرة من حيث انتقاء المواد أو

ترتيبها:

يقصد بهذه المصنفات، المصنفات المختلطة التي تؤدي إلى وضع مصنف فئف فيه ذاتية

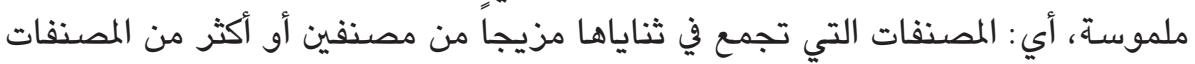

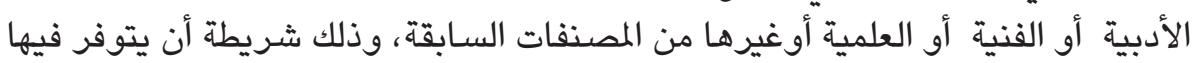

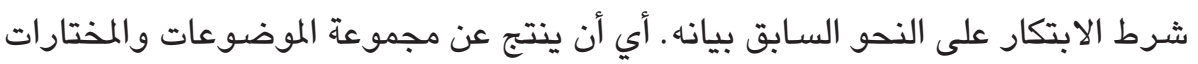

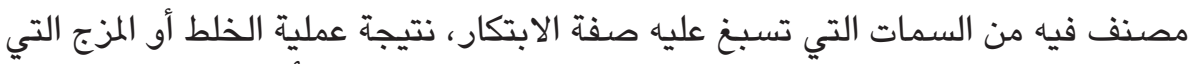

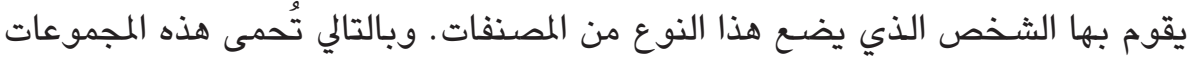

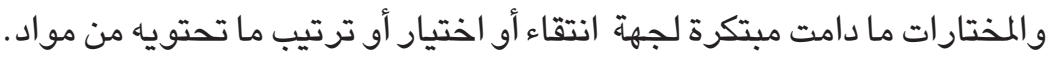

13- قواعد البيانات، إذا ما كانت هذه المجموعات مبتكرة بسبب ترتيبها، أو اختيار محتوياتها:

يتعلق الأمر في هذا النوع من المصنفات بعملية إدارة البيانات بصورة مبتكرة بسبب طريقة ترتيبها أو اختيار محتوياتها، وتنحصر الحماية في هذه الحات الحالة إلى العملية الإبتكارية

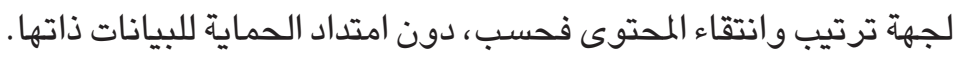
14- مجموعة المصنقات والتعبيرات الفلوكلوريتة، إذا ما كانت هذه المجموعات مبتكرة بسبب ترتيبها أو اختيار محتوياتها:

يعد التراث الشعبي والتعبير الفلكلوري ذاكرة المجتمعات، لذلك يتم نعته -عـادة-

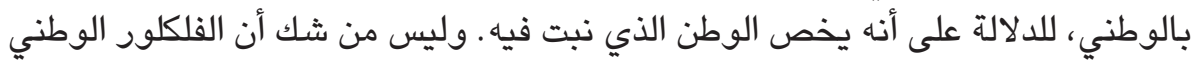

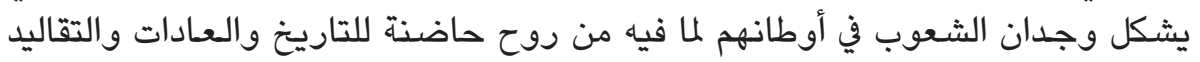

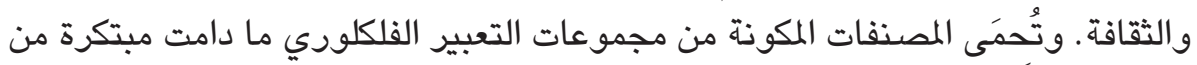
حيث ترتيبهاً واختيار محتوياتها.

وقد عرف القانون القطري الفلكلور الوطني بأنه : كل تعبير يتمثل في عناصر متميزة

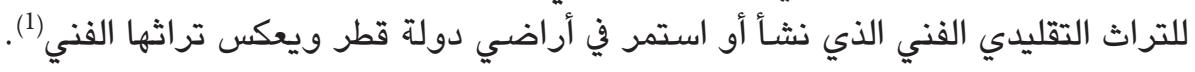


وعليه فإن دائرة التعبير عن الفلكلور الوطني رحبة ومتنوعة، وتتعدد الصور التي يظهر بها، وفي الغالب تأخذ التعبيرات الآتية(1): 1- التعبيرات الشفوية مثل الحكايات والأشعار الشعبية والأحاجي والأمثال والألغاز. 2- التعبيرات الموسيقية مثل الأغاني الشعبية المصحوبة بموسيقى. 3- التعبيرات الحركية مثل الرقصـات الشعبية والمسرحيات والأثكال الفنية والطقوس.

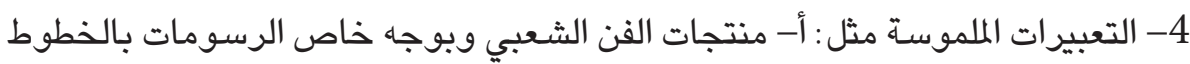

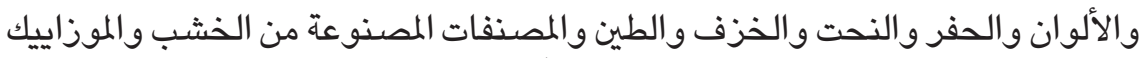

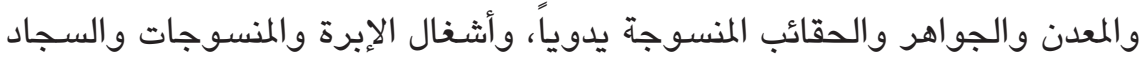

$$
\text { والملبوسات. ب- الآلات الموسيقية. ج- الأشكال المعمارية. }
$$

ويلاحظ أن تعريف القانون القطري للفلكلور الوطني على النحو المتقدم والتوسع في

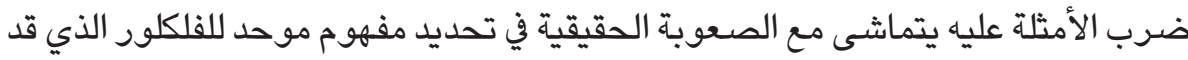

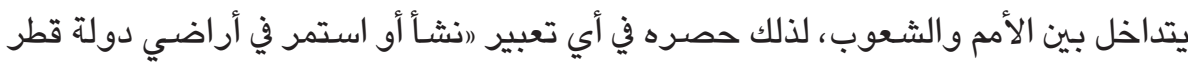

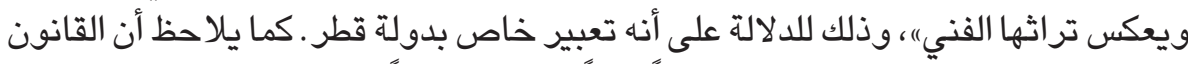

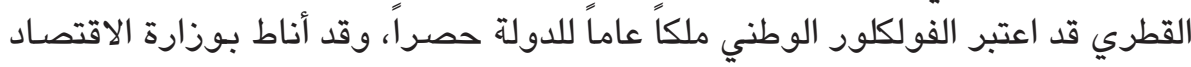

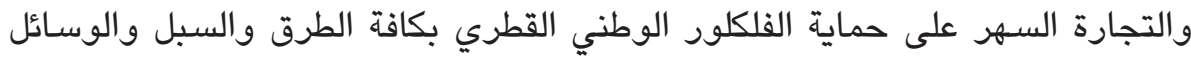

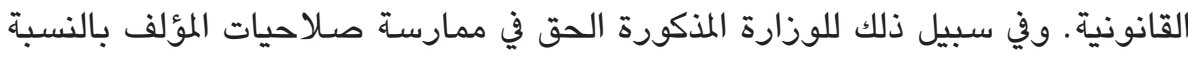

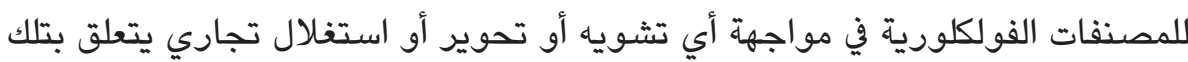

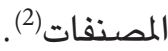

\section{5 منوان المصُنَفْ:}

لم يقف القانون القطري عند حماية المصنفات فحسب، بل وفرو المهر حماية لعناوينها أيضاً،

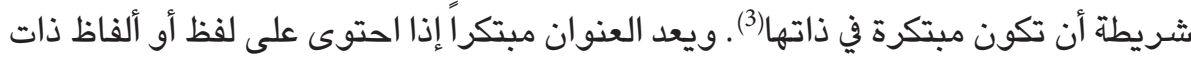

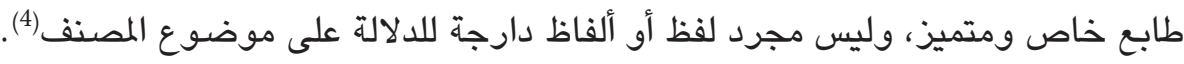

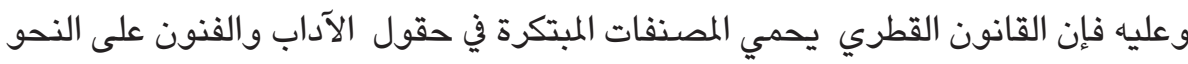

(1) (1) المادة 1 من القانون القطري.

(2) (1) المادة 32 من القانون القطري.

(3) (3) المادة 2 من القانون القطري.

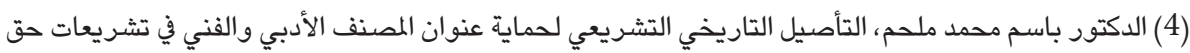

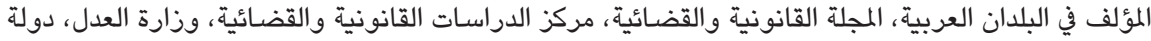

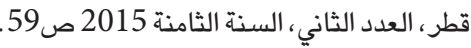


السابق بيانه، وذلك بصرف النظر عن قيمة تلك المصنفات أو نوعيتها أو الغرض من تأليفها

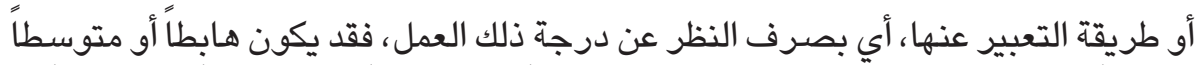

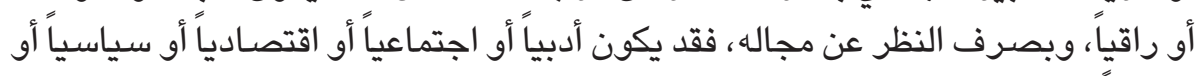

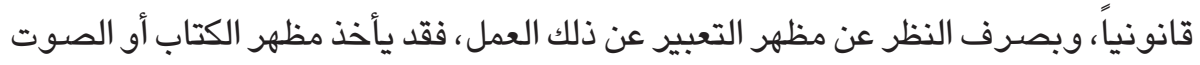

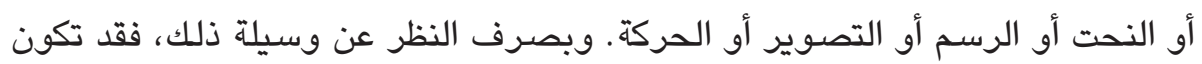
مقروءة أو مسموعة أو مرئية.

ويلاحظ أن المادة 2 من القانون القطري لم تحصر المصنفات المحمية بما سبق ذكره

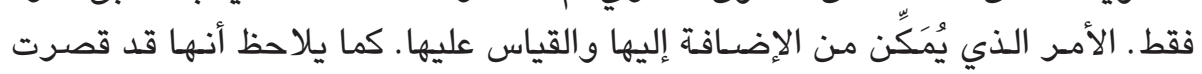

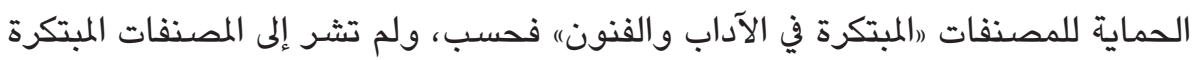

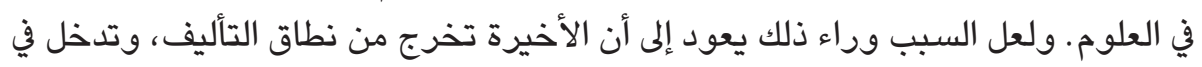

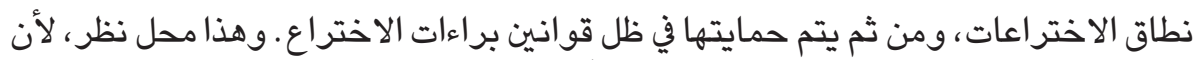

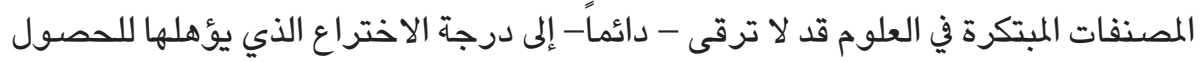

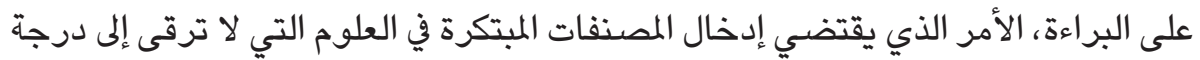

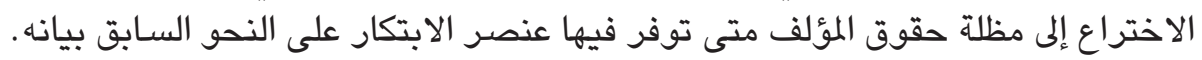
وتجدر الإثـارة إلى أن أحكام القانون القطري تسري لفو على المصنفات التالية(1): 1- مصنفات المؤلفين القطريين التي تنشر داخل الدولة أوخارجها.

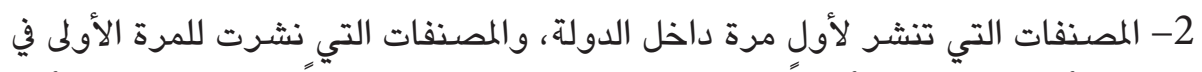

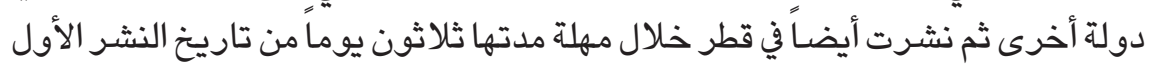
بغض النظر عن جنسية مؤلفيها أو محال إقامتهم.

3- المصنفات السمعية البصرية التي يكون المقر الرئيسي لمنتجها أو محل إقامته في قطر . 4- مصنفات الفن المعماري المشيدة في قطر ، أو أي أعمال فنية أخرى مدمجة في بناء أو في أي لي لمئي أبنية أخرى تقع في قطر.

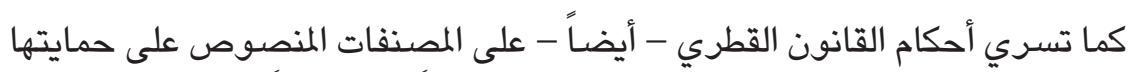
بموجب أي اتفاقية دولية، أو أي اتفاق تكون دولة قطر طرفاً فيه، ووفقاً لأحكامه(2).

(1) (1) (1) (المادة 5 من القانون القطري.

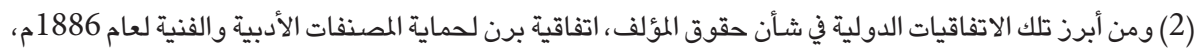

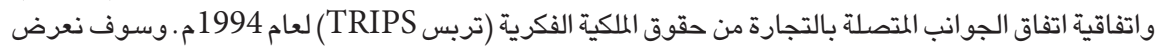
لهما في موضع لاحق. 


\section{الفرع الثاني \\ المصنفات غير المحمية}

المصنفات غيرِ المِحمية هي المصنفات المستبعدة كلياً من الحماية، وقد استبعد القانون

القطري استبعاداً كلياً من نطاق الحماية القانونية الأعمال الآتية (1):

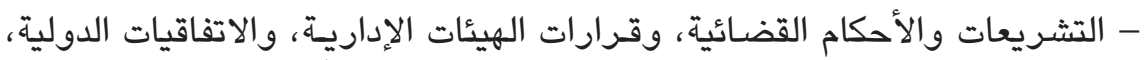

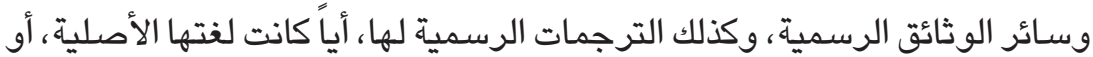
اللغة المنقولة إليها.

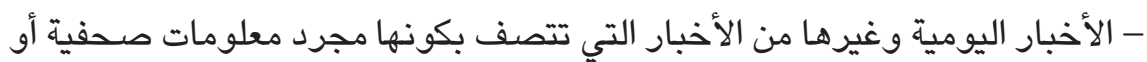

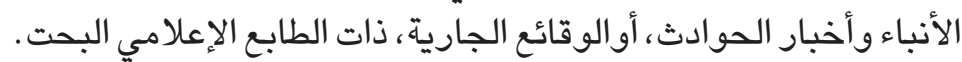

- الأفكار والإجراءات وأساليب العمل والمفاهيم الرياضية، والمبادئ والحقائق المجردة.

ومن نافلة القول أن استبعاد هذه الأعمال أمر مبرد ويعود ذلك لأكثر من سبِ، أبرزها أن أن أنها

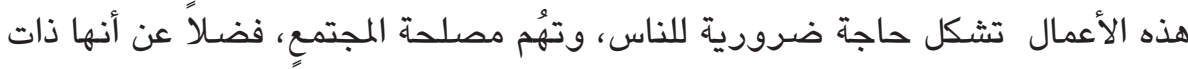

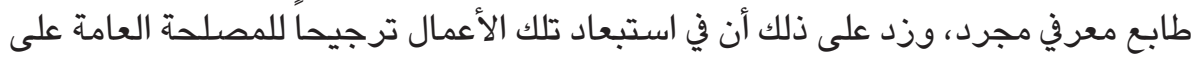

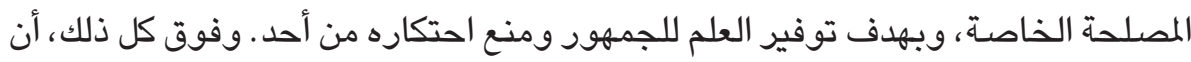

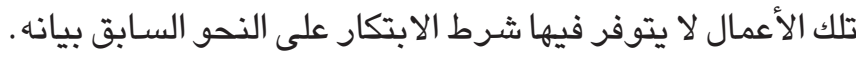

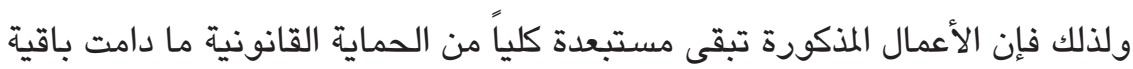

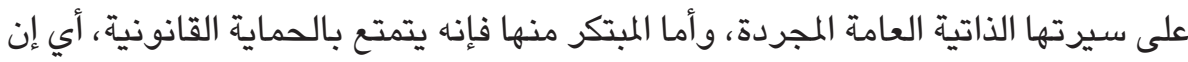

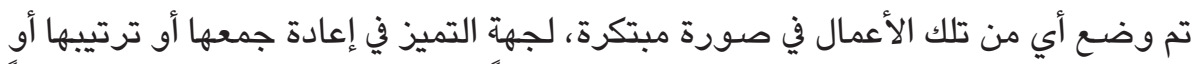
إخرجها ونحو ذلك، فيعد -عندئذ- ذلك العمل مصنفاً ويدخل مظلة الحماية الحمائ القانونية سنداً لصفة الابتكار فيه.

ومن نافلة القول، أنه يلزم أيضًاً، استبعاد المصنفات التي آلت إلى الملك العام من الحماية

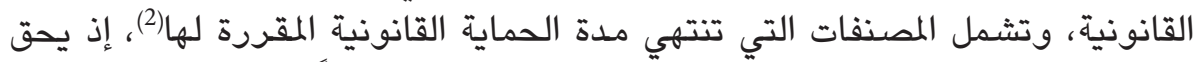

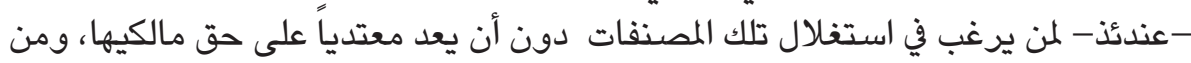
البديهي أن يسري ذلك على جميع المصنفات المستبعدة من الحماية بداية. 
ويلاحظ في هذا الصدد، أن القانون القطري، قد أنـاط بـوزارة الاقتصـاد والتجارة

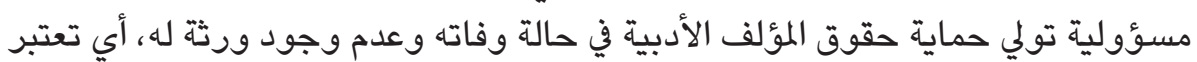
تلك الحقوق من قبيل الملك العام(1).

\section{المطلب الرابع}

\section{حقوق المؤلف المعنويـة والمالية}

يتمتع المؤلف على مصنفه بنوعين من الحقوق ، وهما الحقوق المعنوية والحقوق المالية.

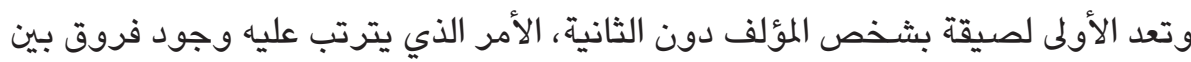

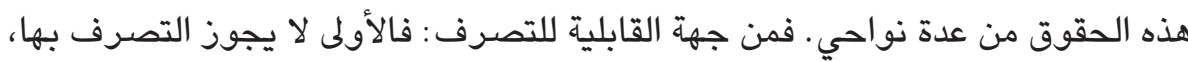

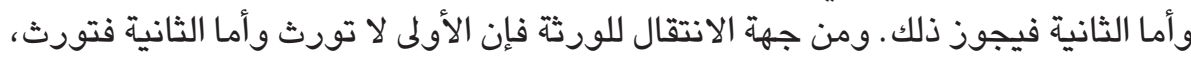

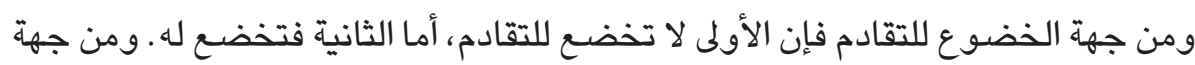

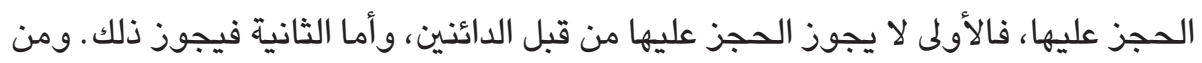
جهة مدة الحماية، ، فإن الأولى أبدية، وأما الثانية فمؤقتة (2). ويرتب القانون القطري للمؤلف على مصنفه جملة من الحقوق المعنوية والمالية. و ونحاول في هذا المطلب، الوقوف على هذه الحقوق من خلال الفروع التالية :

\section{الفرع الأول}

\section{حقوق المؤلف المعنويـة}

تعد حقوق المؤلف المعنوية (الأدبية) من الحقوق اللصيقة بشخص المؤلف، لأنها تعبر

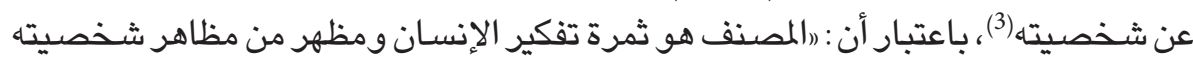

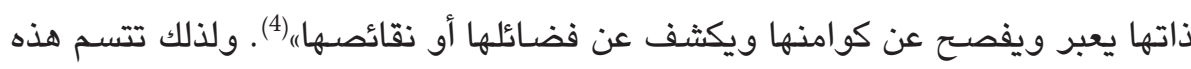

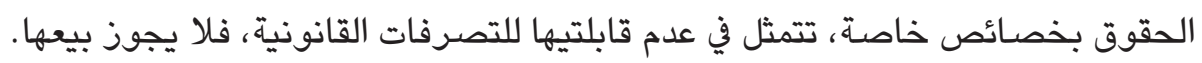

(1) (1) (المادة 17 من القانون القطري.

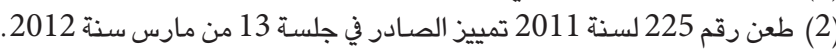

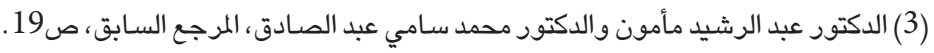

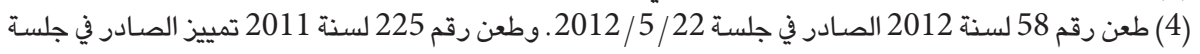
$2012 / 3 / 13$ 
وأنها لا تخضـع للتقادم، فلا تسقط بمرور الزمن، كما أنها لا تنتقل إلى الورثة، فلا تعد أموالاً

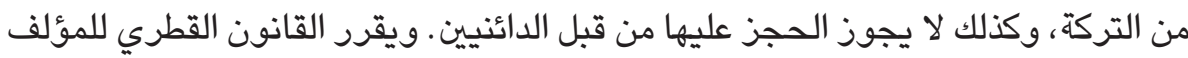

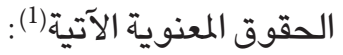

\section{1) حق المؤلف في تقرير نثر مصنفه لأول مرة:}

يقصد بحق المؤلف في تقرير نشر مصنفه لأول مرة، أن يكون للمؤلف وحده تحديد

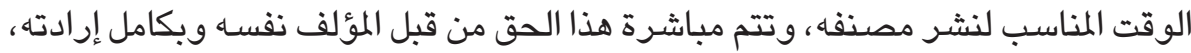

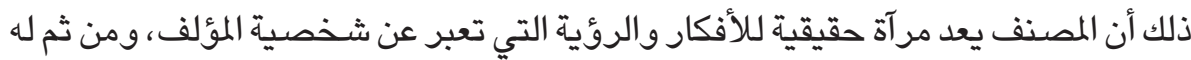

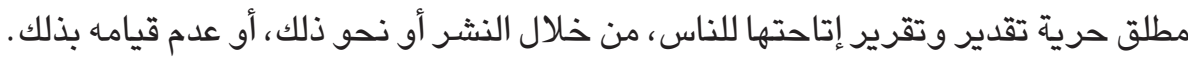

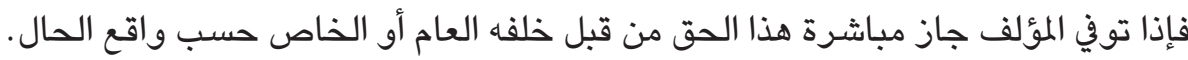

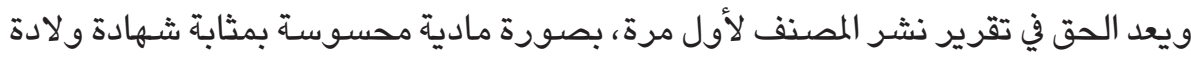

للمصنف.

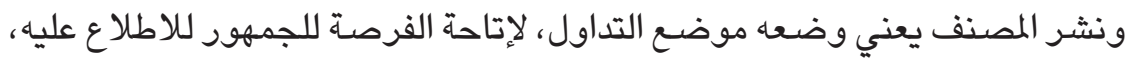

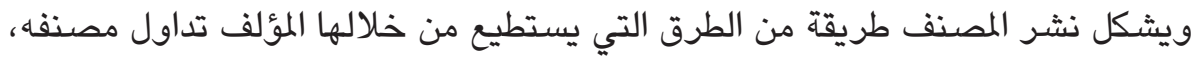

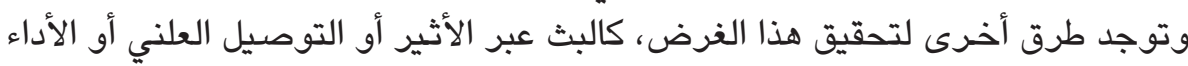
العلني، أو نحو ذلك.

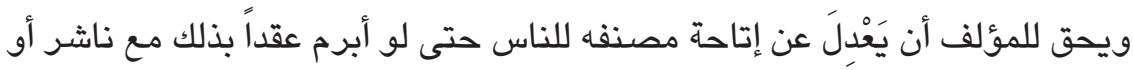

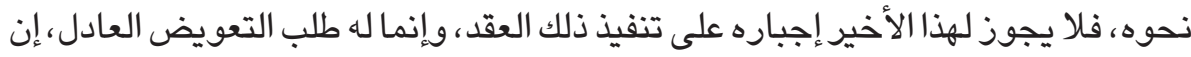

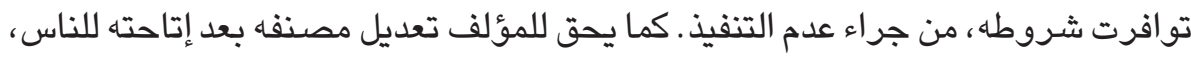

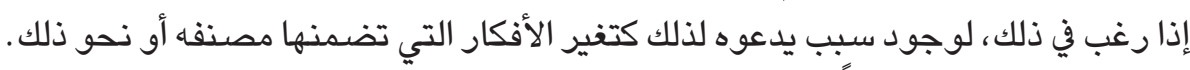

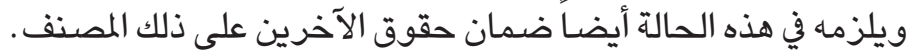

2) حق المؤلف في أن ينسب إليه المصنف بذكر اسمه عليه، أو بـاسم مستعار، أو أن لا

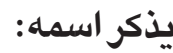

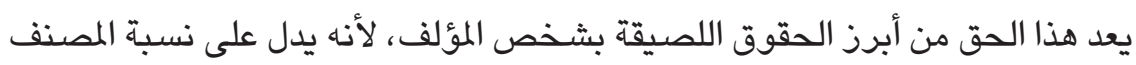

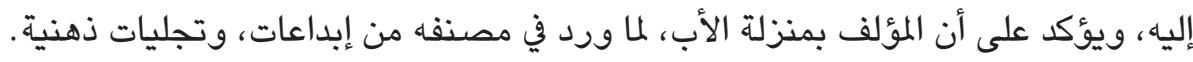

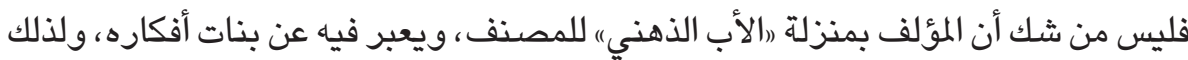

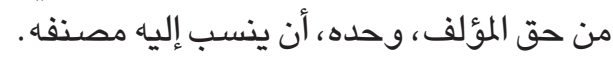

(1) (1) - (المادة 10 من القانون القطري. 


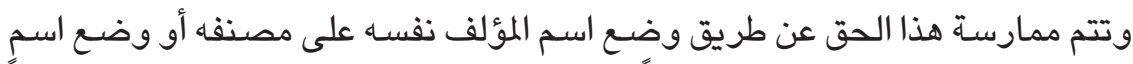

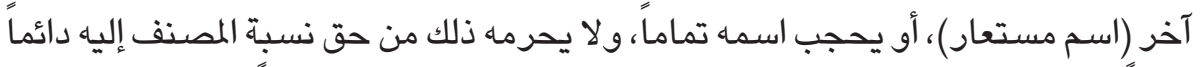

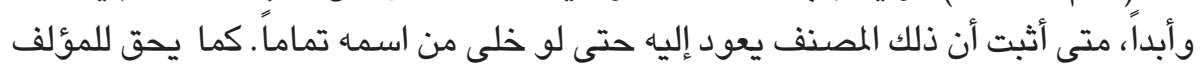

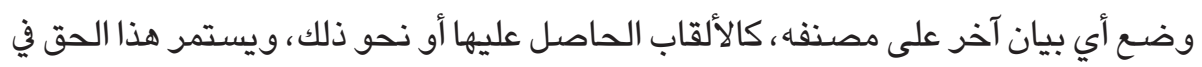

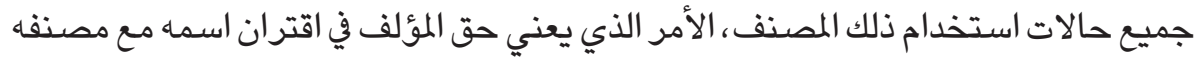

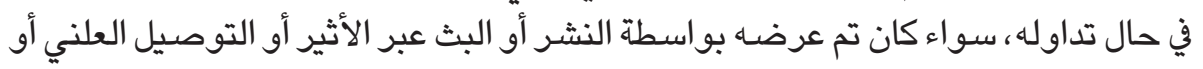

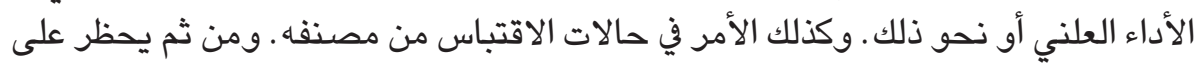

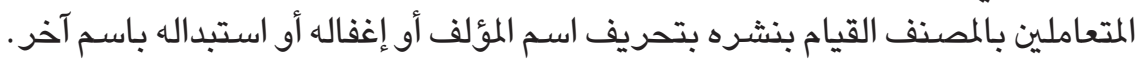
3) حق الاعتراض ومنع كل تحريف أو تشويـ أو تعديل آخر لمصنفه:

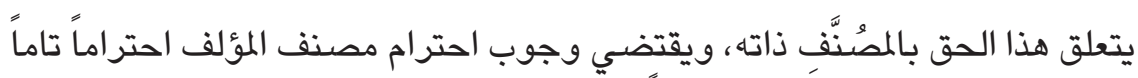

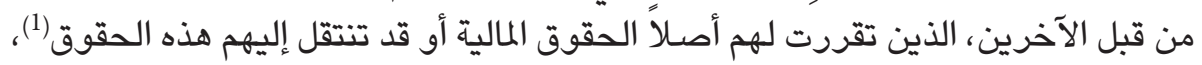

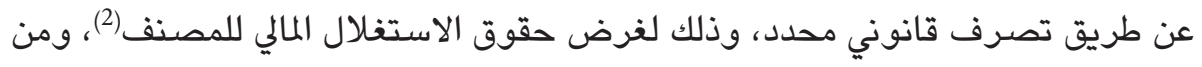

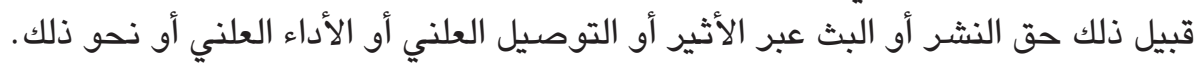

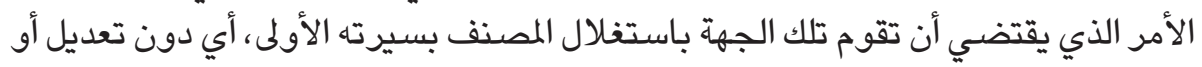

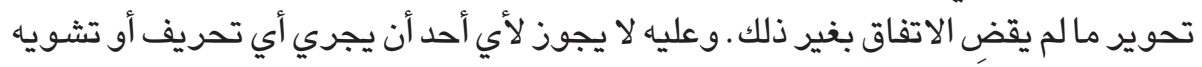

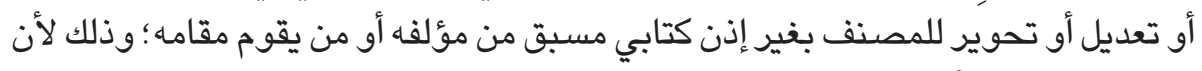

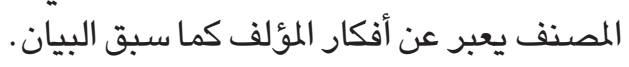

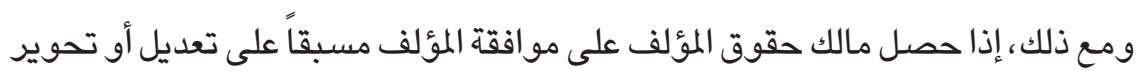

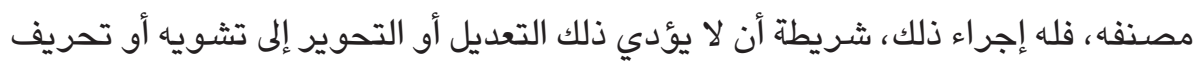

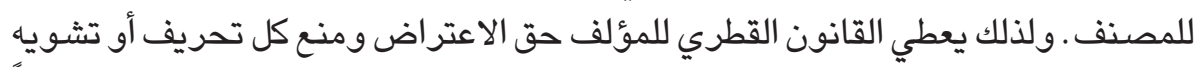

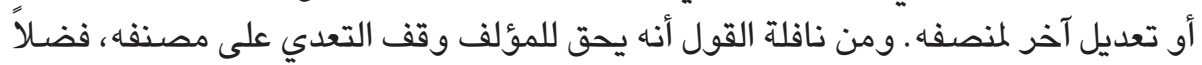
عن المطالبة بالتعويض عن ذلك.

4) حق الاعتراض ومنع أي استعمال للمصنف يمكن أن يسيء إلى شرفه أوسمعته:

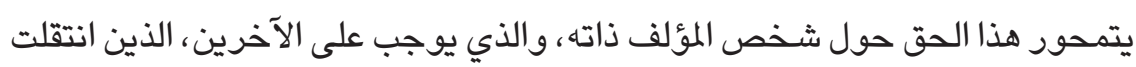

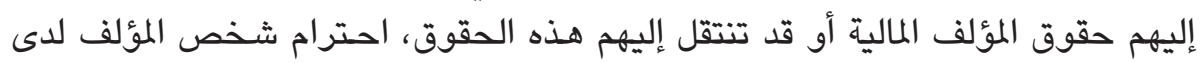

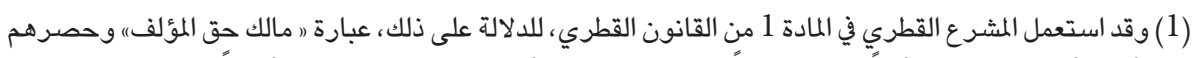

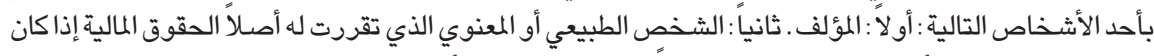

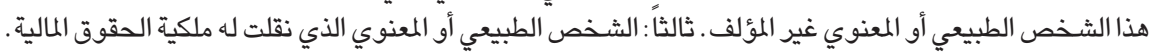
(2) (2) (المادة 7 من القانون القطري. 


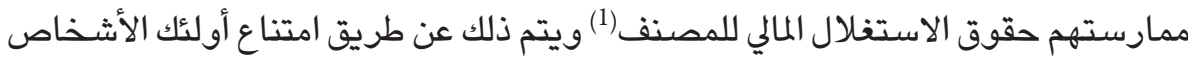

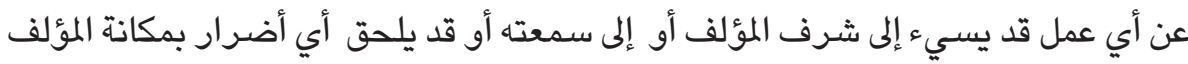
الإدبية أو الفنية.

5) حق سحب مصنفه من التداول أو إجراء أي تعديل بالحذف أو الإضـافة فيه:

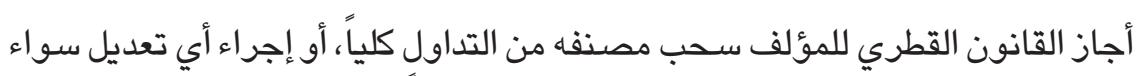

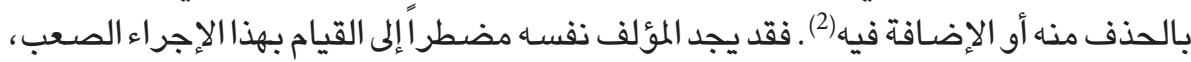

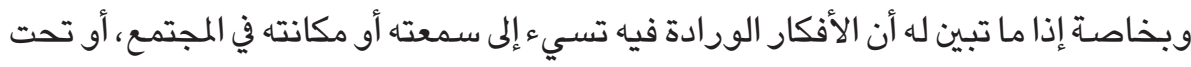

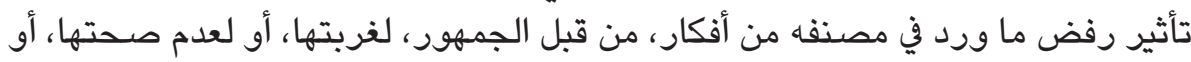

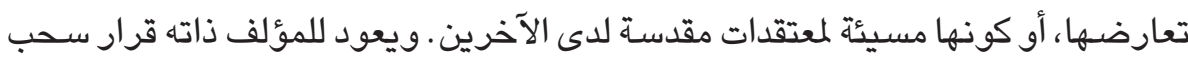

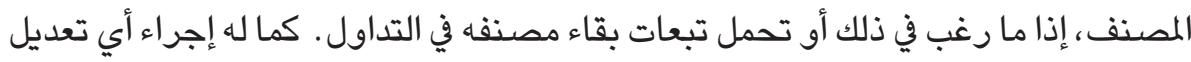

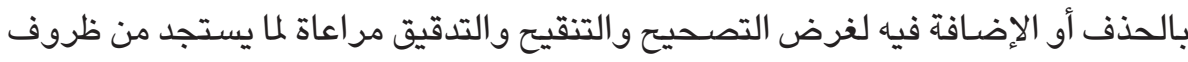

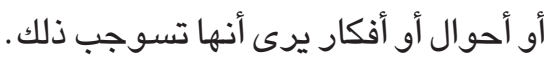

ويستطيع المؤلف ممارسة هذا الحق بلا أدنى صعوبة تذكر، وذلك في حالة الن أن تكون

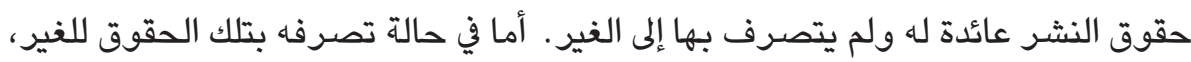

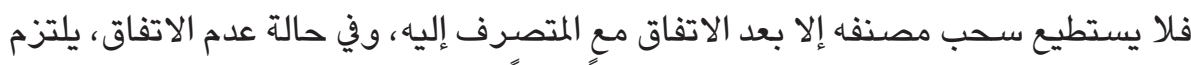

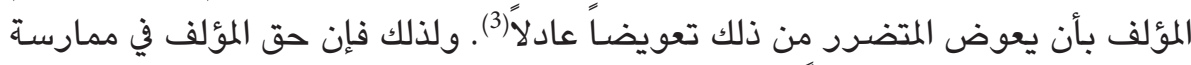

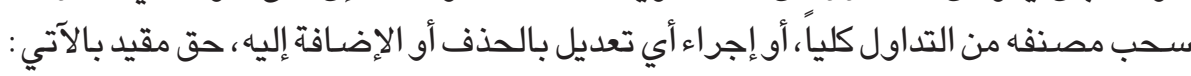
أ- أن تطر أ أسباب جدية تبرر طلب سحب المصنف، ومن قبيل ذلك : تبدل في أفكار أو آراء أو بال

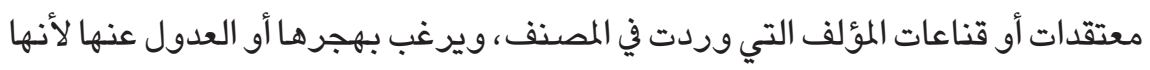

$$
\text { تسيء لشخصه أو لسمعته أو مكانته أو للغير . }
$$

ب- الاتفاق مع المتصرف إليه بحقوق النشر (أي مالك حقوق المؤلف المالية).

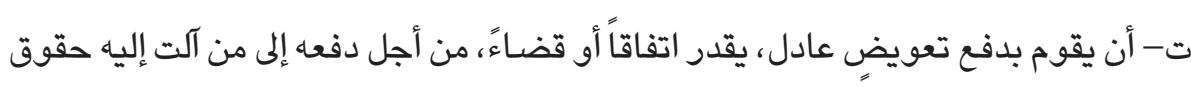

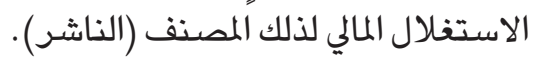

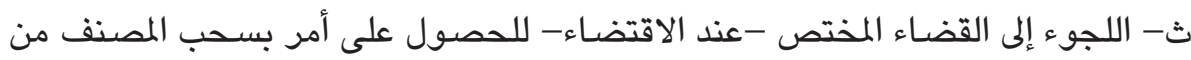

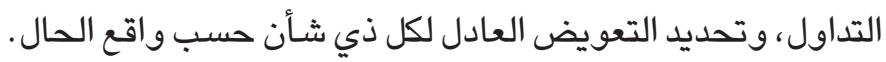




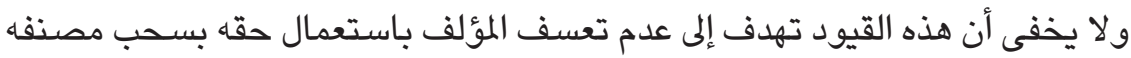

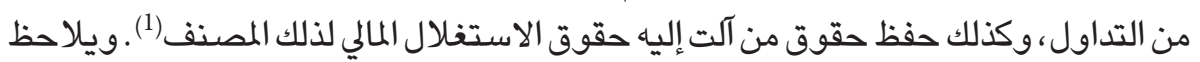

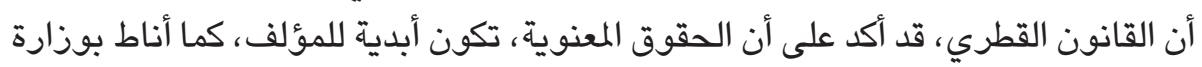

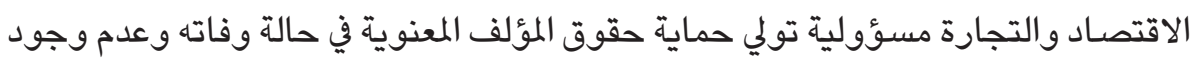
ورثة له (2).

\section{الفرع الثاني}

\section{حقوق المؤلف المالية}

إن حقوق المؤلف المالية -على العكس من حقوق المؤلف المعنوية التي سبق بيانها-

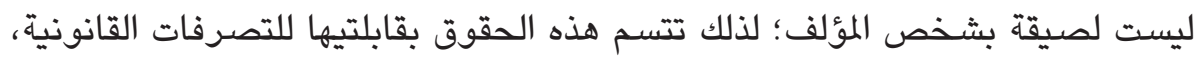

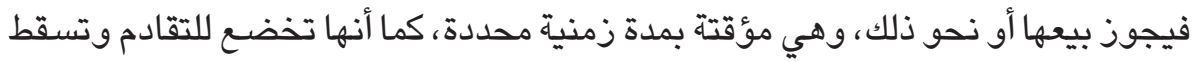

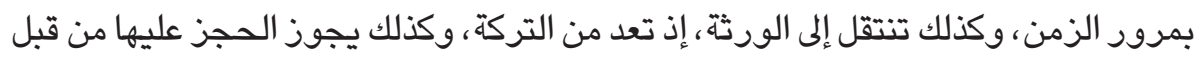

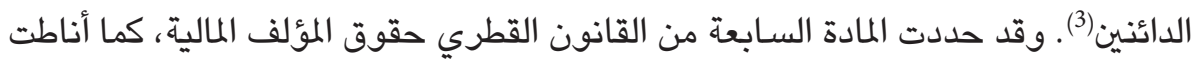

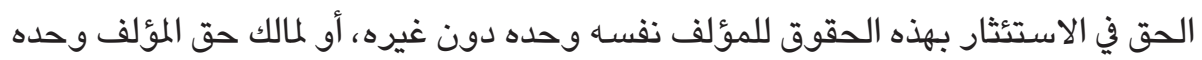

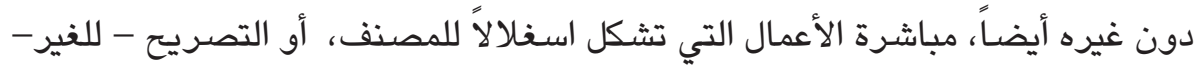

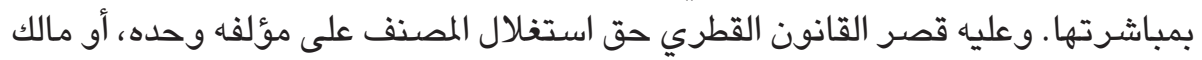

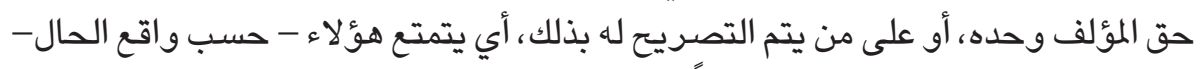
بحق الاستئثار بثمار المصنف حصدئ عصدياً.

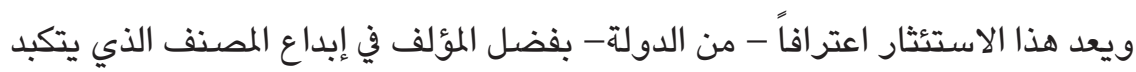

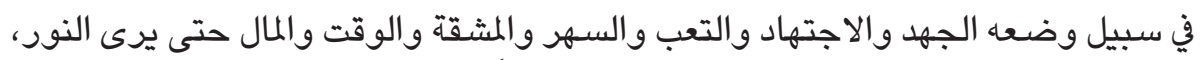
ويروى أن المأمون كان يعطي المؤلف زنة مصنفه ذهباً مكافأة له على ذلك.

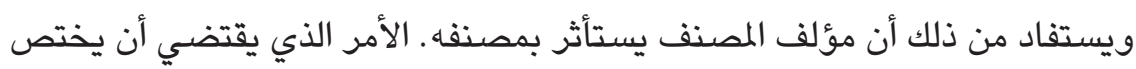

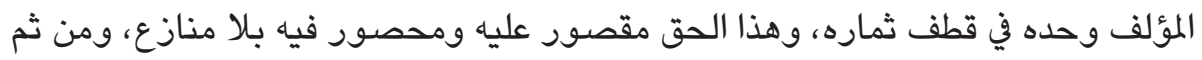

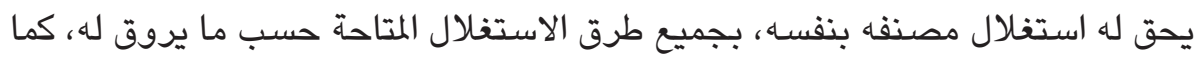

$$
\begin{aligned}
& \text { (1) الدكتور عبد الرشيد مأمون والدكتور محمد سامي عبد الصـادق، المرجع السابق ، ص292. }
\end{aligned}
$$

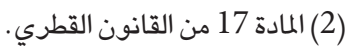

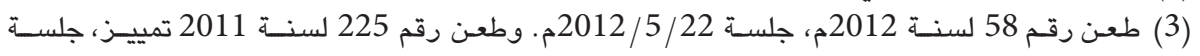
2012/3/ 13 
يحق له التصريح للغير القيام بذلك بمقابل أو بدون مقابل، ولا يجوز لغيره مباشرة هذا

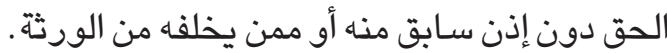

وعليه، يعطي حق الاستئثار للمؤلف على مصنفه، الحق في استغلال مصنفه بالصورة

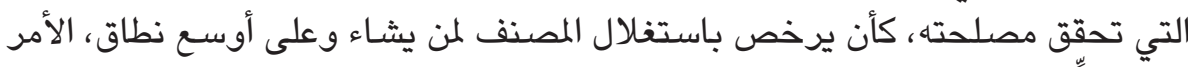
الذي يُمكِّن المؤلف من قطف ثمار إبداعه، ومن ثم جني حقوق مالية جمة .

ومع ذلك، فإن هذا الحق الاستئثاري والحصري للمؤلف على مصنفه، ينتقل بإذنه إلى إنى خلفه الخاص (الناشر) الذي يرخص له فانه باستغلال مصنفه خلال حياته ، كما أنه ينتقل قدراً

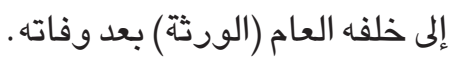

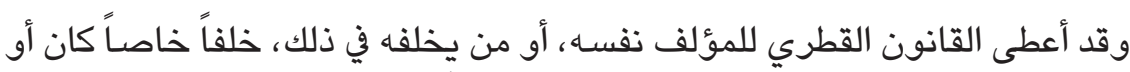

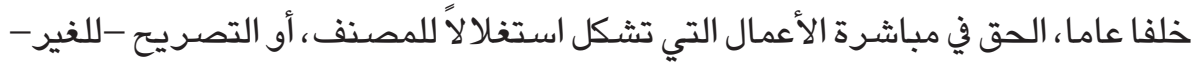

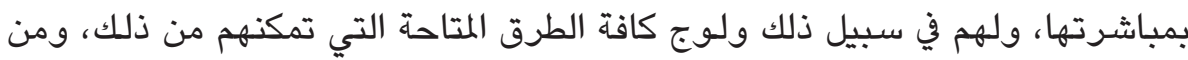
أبرزها الآتي (1): - (1) 1- استنساخ المصنف:

يعد استنساخ المصنف من الصور الرائجة في استغلال المصنف، ويقصد به التثبيت

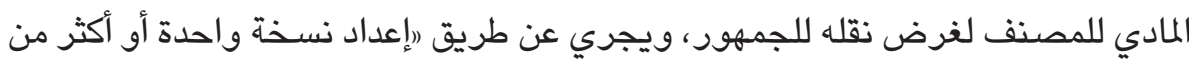

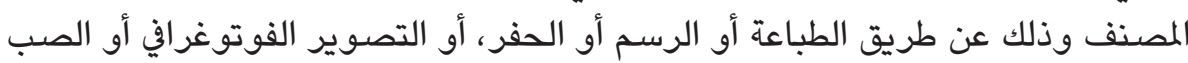
في قوالب أو بـأي وسيلة وفي أي شكل آخر بما في ذلك التخزين الدائم أو المؤقت في شكل أن الته إلكتروني"(2).

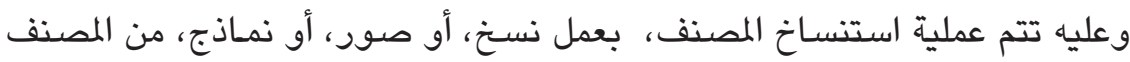

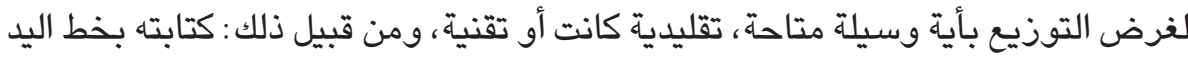

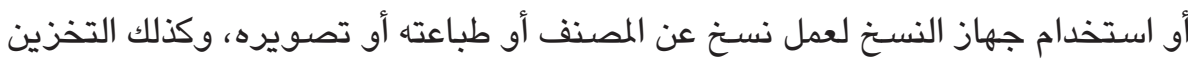

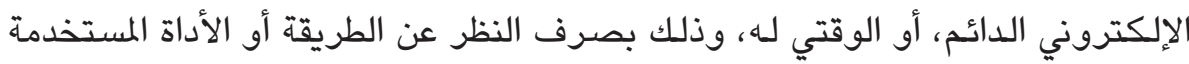

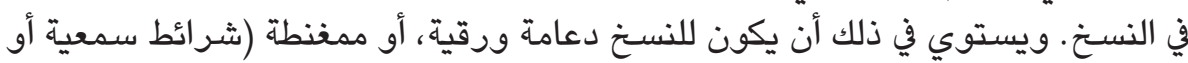

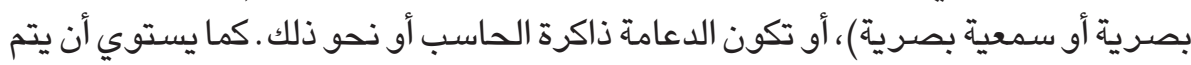

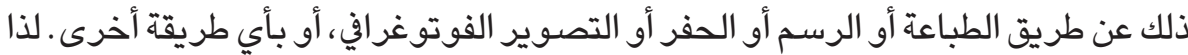

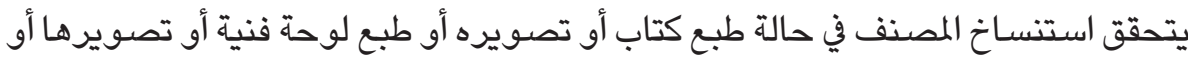

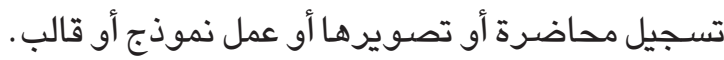




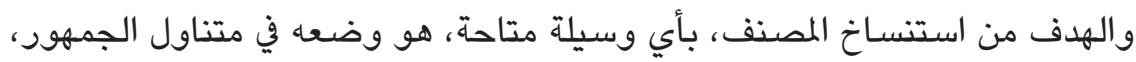

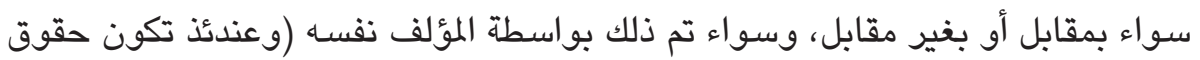

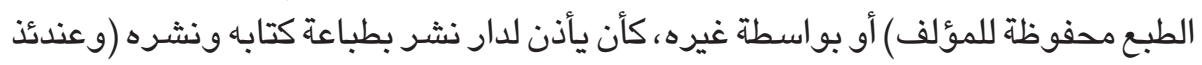

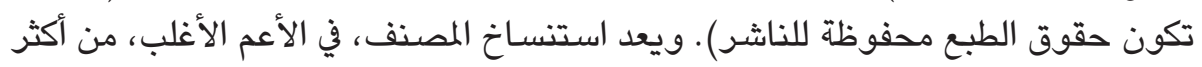

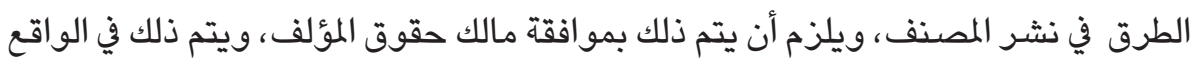
العملي، من خلال عقد النشر (1).

$$
\text { 2- ترجمة المصنف: }
$$

قد يكون المصنف موضوعاً بلغة معينة، وعلى قدر كبير من الأهمية، ثم تتم ترجمته

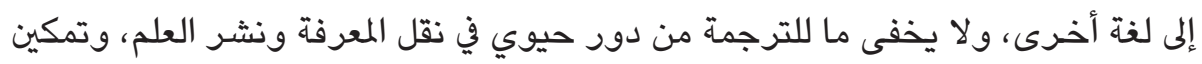

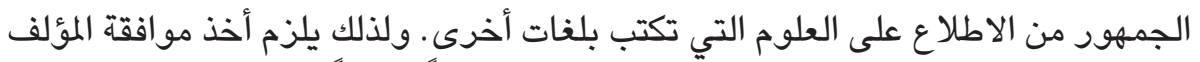

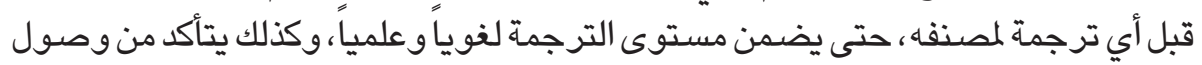

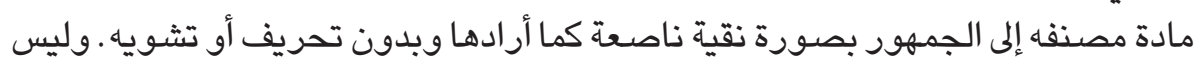

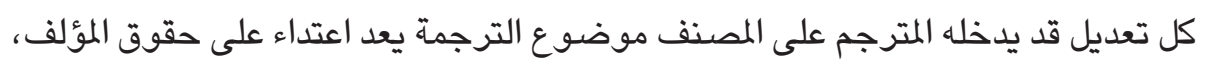

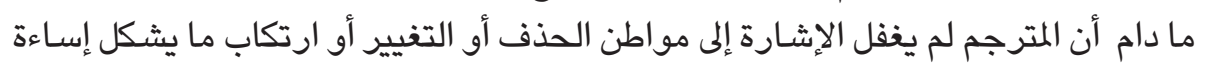

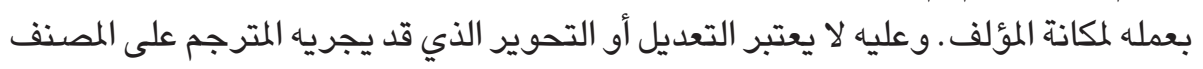
موضوع الترجمة، اعتداء على حقوق المؤلف، شريطة توفر الآتي (2):

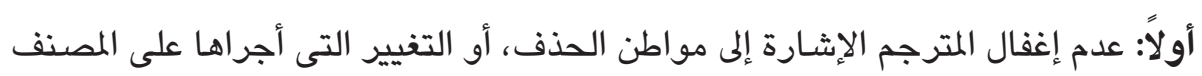

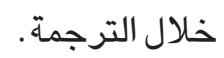

ثانياً: عدم الإسـاءة بعملية الحذف أو التغيير لسمعة مؤلف المصنف أو مكانته الأدبية أو الفنية.

$$
\text { 3- التعديل: }
$$

يحق للمؤلف أن يقوم بتعديل مصنفه، ويتم التعديل عن طريق الحذف منه أو الإضـافة

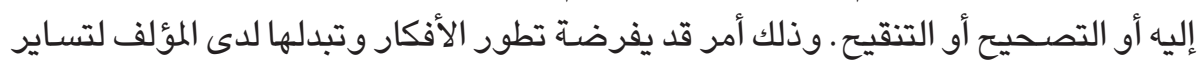

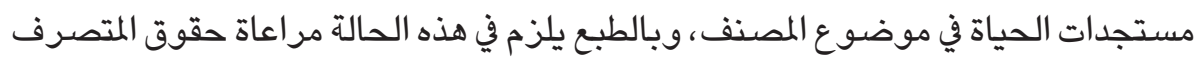
إليه بحق النشر.

(1) المثادة 8 من القانون القطري، وسوف نعود لهذه المسألة في موضع لاحق. (2) الدكتور محمد حسام محمود لطفي، المدخل لدراسة القانون في ضون ألماء آراء الفقه وأحكام القضاء، القاهرة الطبعة السادسة سنة 2008. ص498. 


\section{4- اتتباس أو توزيع موسيقى، أو إجراء أي تحوير آخر للمصنف:}

يحق للمؤلف إعطاء الإذن للغير بالاقتباس من مصنفه أو توزيعه موسيقاً أو تحويره

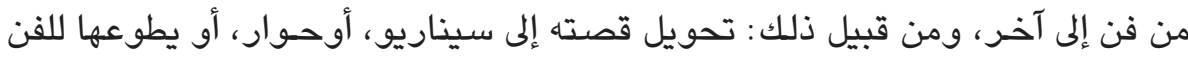
السينمائي بمعالجة فنية، ومن ثم يظهر المصنف بعد تحويره في ثوب جديد. وهذا كله مشـروط بإذن المؤلف على أن لا يتجاوز التحوير روح النص، وفي حدود هذا الإذن الصـادر له بالتحوير.

\section{5- توزيع المصنف على الجمهور من خلال البيع:}

يتمتع المؤلف بحقه في توزيع نسخ مصنفه لغيره عن طريق البيع أو أي تصرف آخر ناقل للملكية، ،ظير مقابل يرتضيه لقاء ذلك. ويتم ذلك -عادة- عن طريق توفير نسـخ كافية من المصنف أو من التسـجيل السـمعي لتلبية حاجات الجمهور ، وذلك بموافقة المؤلف أو مالك حقوق المؤلف أو منتج التسـيل السمعي.

6- التأحير للجمهور بالنسبة للمصنفات السمعية البصريتة وبرامج الحاسب الآلي، ومع ذلك لايطبق حق التأجبر إذا لم يكن برنامج الحاسب نفسه الموضوع الأساسي للتأجير: يحق للمؤلف أن يقوم بتأجير مصنفه لقاء عائد مالي يتفق عليه. . ويتم ذلك عن طريق

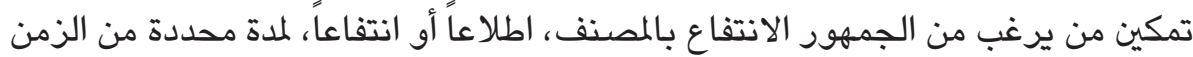
لقاء بدل معلوم، سـواء تم ذلك من قبل المؤلف نفسـهـ أو من قبل شـركات محترفة . ويلاحظ أن القانون القطري قد قيد تأجير "برامـج الحاسب الآلي" و"برامج المصنفات السمعيةة) بخرورة أن يكون برنامج الحاسب نفسه هو المحل الأسـاسي للتأجير، وكذلك

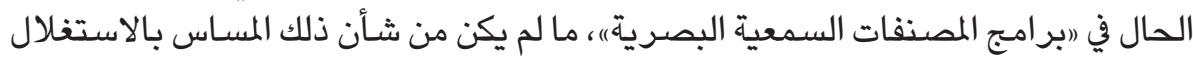
العادي لها. 7- الأداء العلني للمصنف: يـؤدي الأداء العلني للمصنف إلى اتصال الجمهور بالمصنف اتصالاً مباشراً، ومن قبيل ذلك، التلاوة العلنية للمصنفات (أو جزء أو أجزاء منها) بواسطة المسرح أو الإذاعـة

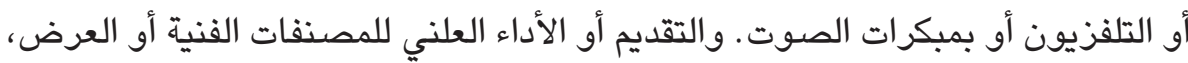
للمصنفات السمعية البصرية والعزف للمصنفات الموسيقية والتلاوة للمصنفات الأدبية. ويستوي في ذلك، أن يكون الأداء بصورة حية، يقوم به أشخاص مؤدون (ممثلون أو عازفون

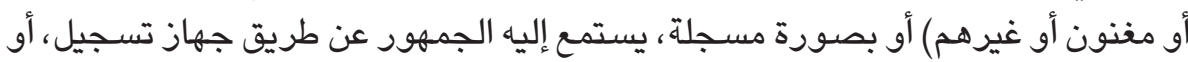

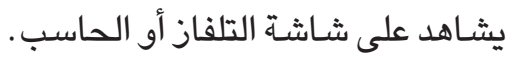




\section{8- نقل المصنف إلى الجمهور:}

يتم نقل المصنف إلى الجمهور عن طريق الإذاعة، ويتم ذلك بنقل المصنف أو الأداء أو

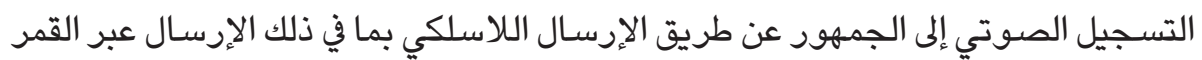

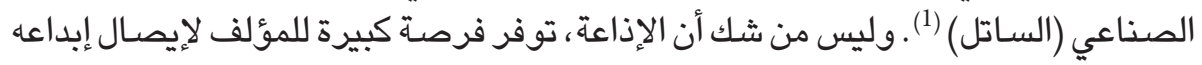

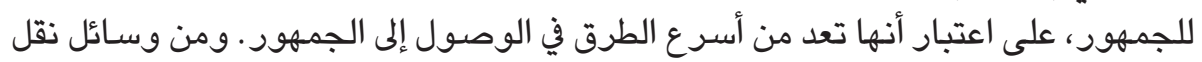

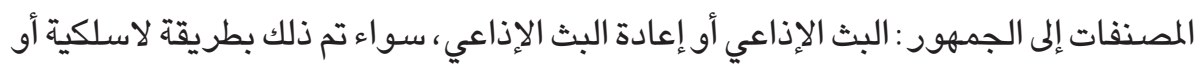
عبر التوابع أو الأقمار الصناعيةهات.

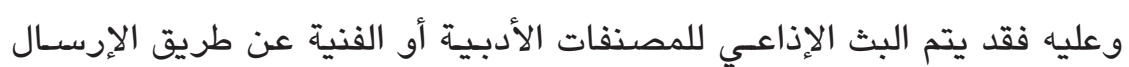

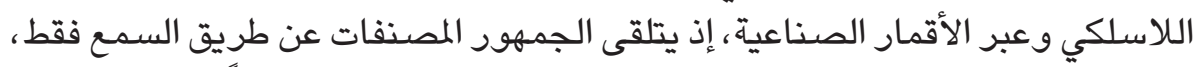

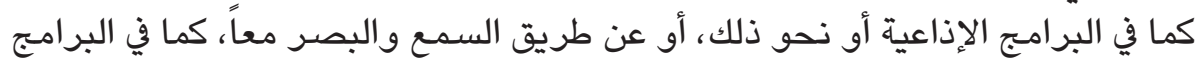

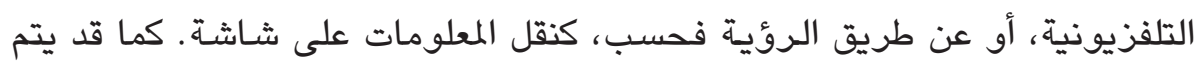

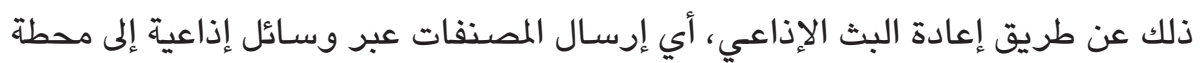

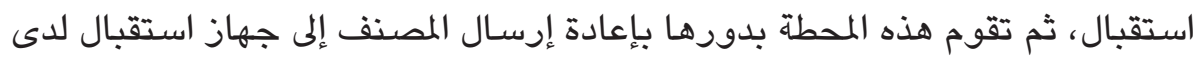

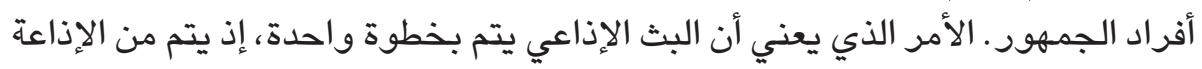

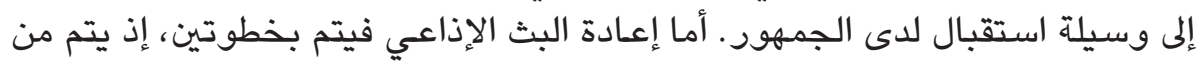

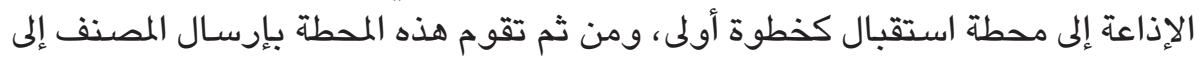
وسيلة استقبال لدى الجمهور كخطوة ثانية.

ويبدو أن حق المؤلف في استغلال مصنفه، ليس محصوراً بما سبق ذكره من وسائل

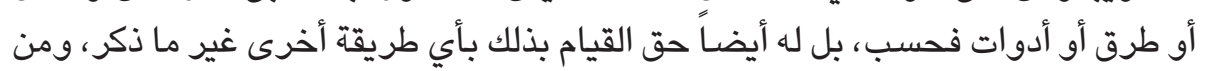

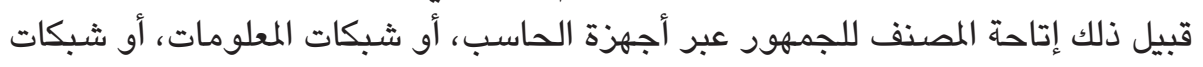
الاتصال، وغيرها من الوسائل التي قد يقذف بها التها التطور التقني (2).

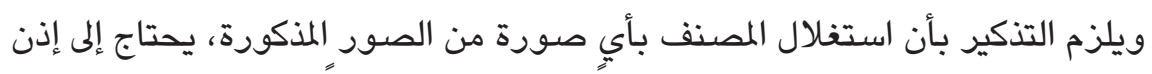

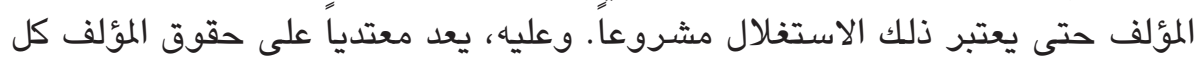

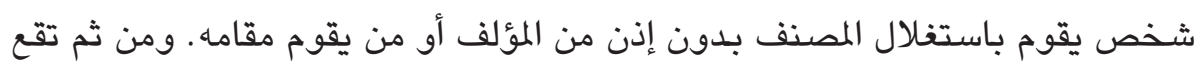

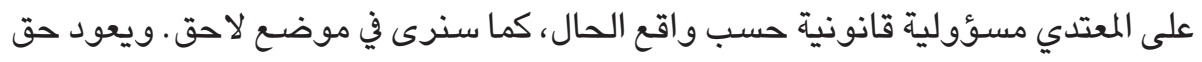

(1) (1) (المادة 1 من القانون القطري.

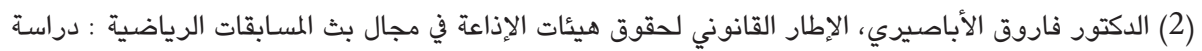

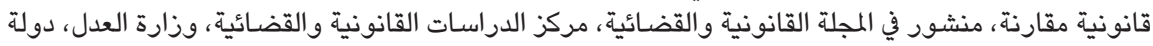

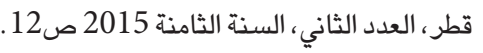


مباشرة حقوق المؤلف المالية إلى مالك حق المؤلف، وقد حدد القانون القطري هذا الأخير بأحد

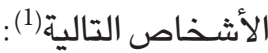
1- المؤلف نفسها.

2- الشخص الطبيعي أو المعنوي الذي تقررت له أصلاًا الحقوق المالية إذا كان هذا الشخص الطبيعي أو المعنوي غير المؤلف. ألفي المعني الذي 3- الشخص الطبيعي أو المعنوي الذي نقلت له ملكية الحقوق المالية. الفرع الثالث

\section{مدة حماية حقوق المؤلف المالية}

يحدد القانون القطري المدد الزمينة للحماية القانونية للحقوق المالية للمؤلف وللمصنفات الأدبية والفنية على النحو الآتي (2): أولاً: تستمر الحقوق المالية للمؤلف مدة حياته، والخمسين سنة من أول السينة التالية لوفاته . ثانياً: تستمر الحماية بالنسبة للمصنفات وفقاً للمدد التالية: 1- المصنفات المشتركة لمدة خمسين سنة تبدأ من أول السنة التالية لوفاة آخر المؤلفين.

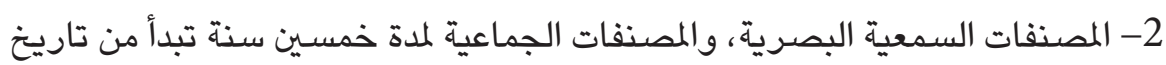

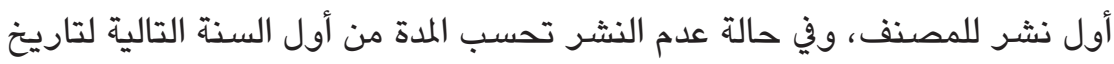
إنجاز المصنف.

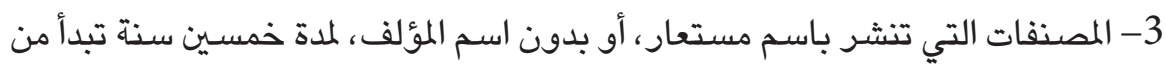

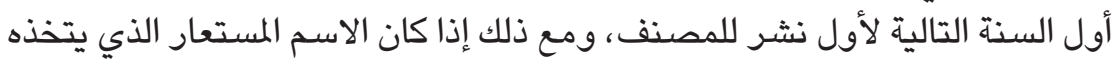

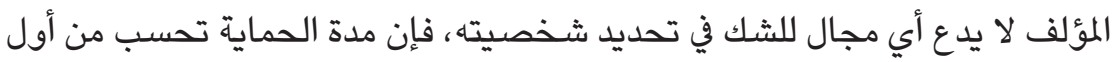

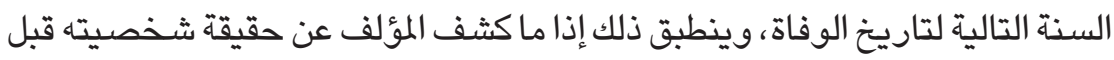
انقضاء مدة الحماية.

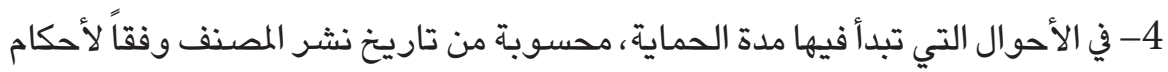

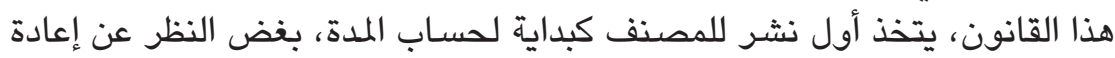

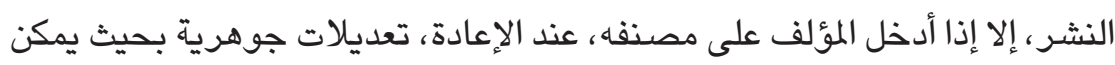


اعتباره مصنفاً جديداً. فإذا كان المصنف يتكون من عدة أجزاء أو مجلدات، ونشرت

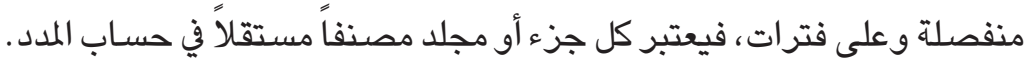

ومن نافلة القول، أنه لدى انقضاء مدد الحماية القانونية لحماية حقوق المؤلف المالية

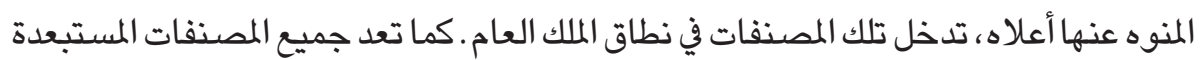

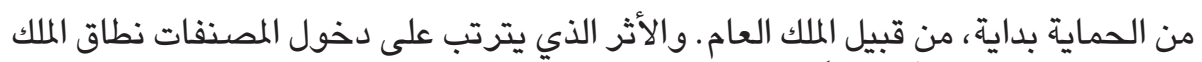

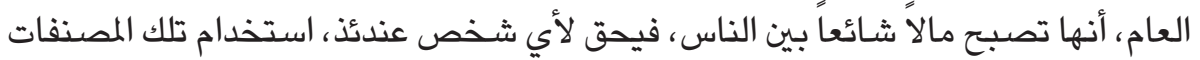

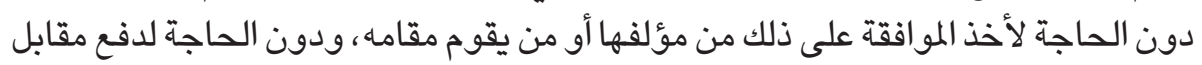

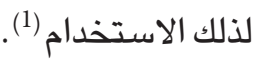

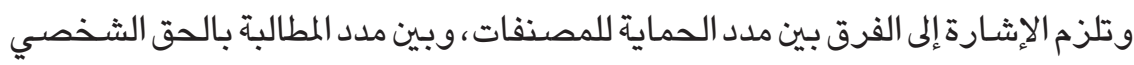

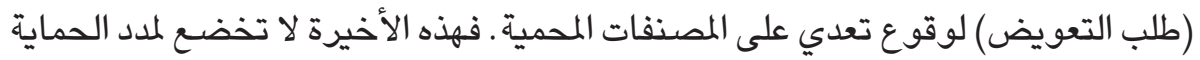

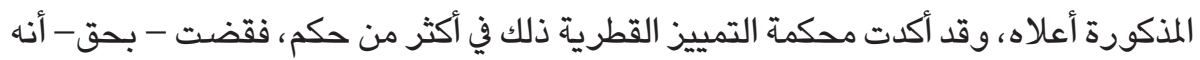

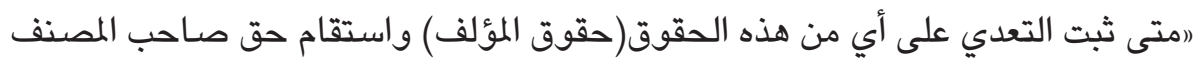

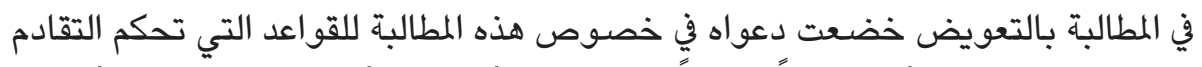

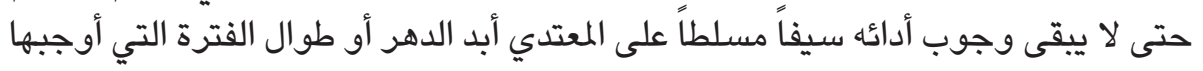

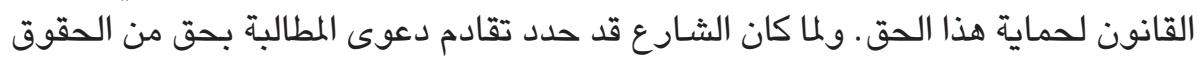

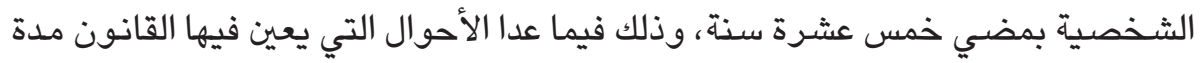

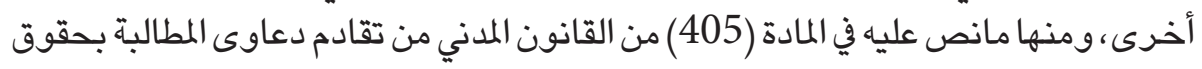

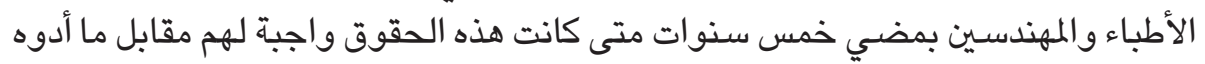

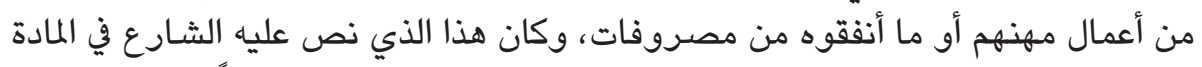

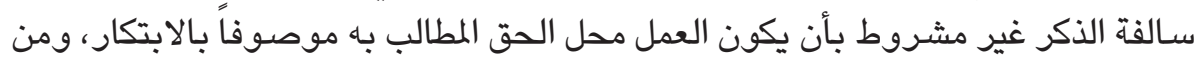

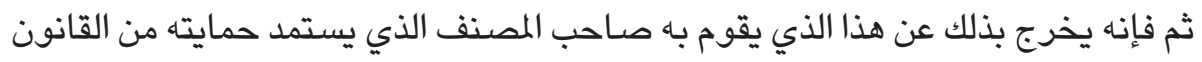

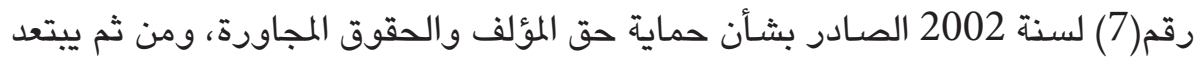

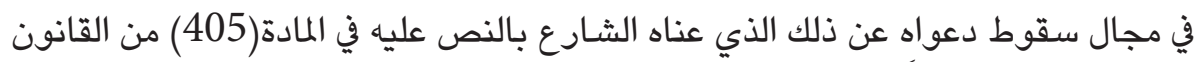

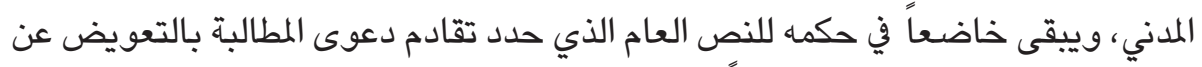

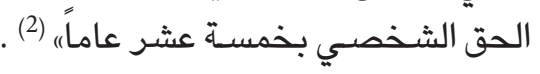

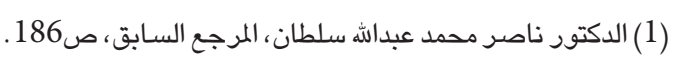

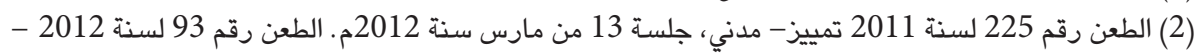

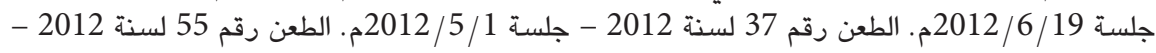

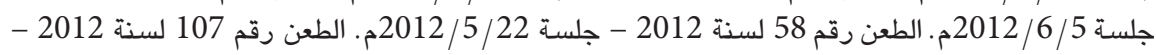

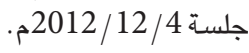




\section{المطلب الخامس \\ التصرف بحقوق المؤلف المالية}

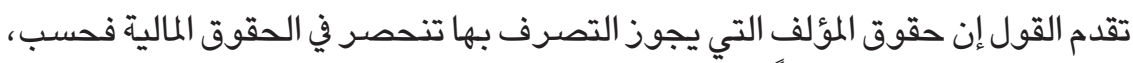

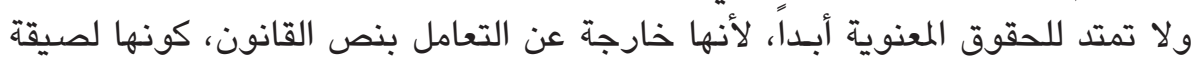

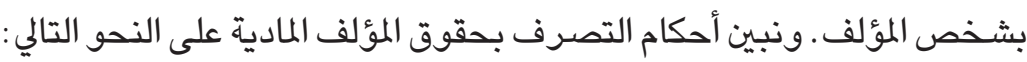

\section{الفرع الأول}

\section{نقل حقوق المؤلف المالية}

حدد القانون القطري إطـاراً عاماً لأحكام نقل المؤلف لأي حق من حقوقه المالية على

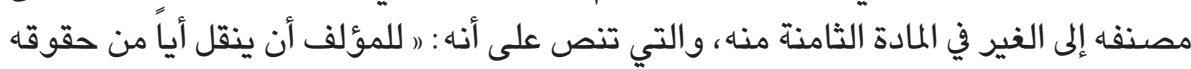

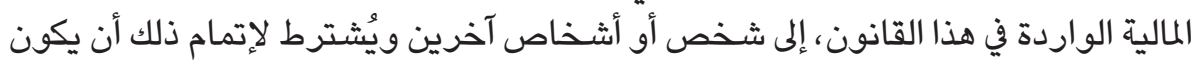

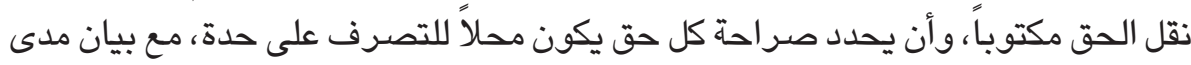

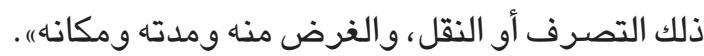

وعليه فإن القانون القطري يعطي للمؤلف، حق التصرف أو حق نقل حقوقه المالية في مصنفة وفقا للشروط التالية: 1- أن يتم التصرف أوالنقل بموجب إبرام عقد مكتوب. 2- أن يحدد الحق محل التصرف أوالنقل بصورة صريحة مفصلة. 3- أن يحدد نطاق التصرف أوالنقل ومدى ذلك. 4- أن يحدد الغرض من التصرف أوالنقل. 5- أن تحدد المدة الزمنية التي يستمر فيها التصرف أو النقل. 6- أن يحدد المكان الذي يسري فيها التصرف أوالنقل.

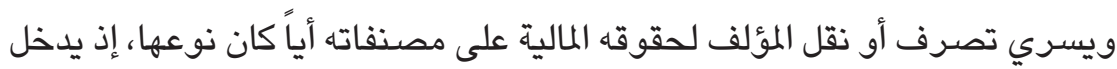

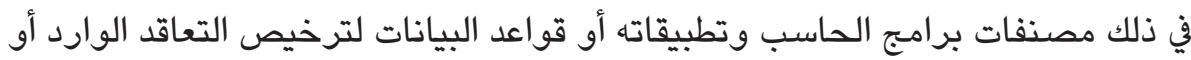

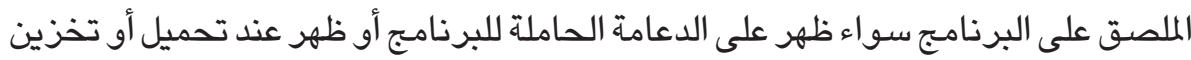


البرنامج في شـاشـة الحاسب، ويكون مشتري البرنامج أو مستخدمه ملزماً بالشروط الواردة

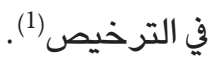

ويلاحظ أن القانون القطري قد استعمل في المادة 8 كلمة "ينقل) وليس كلمة (يبيع)، للدلالة

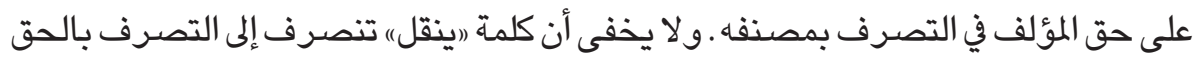

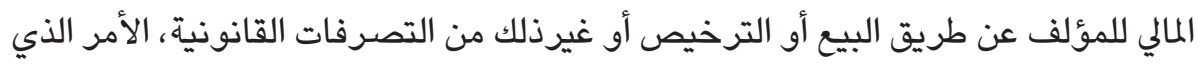

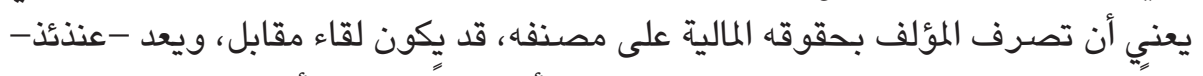

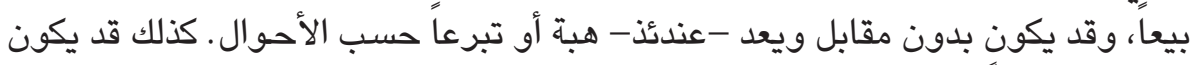

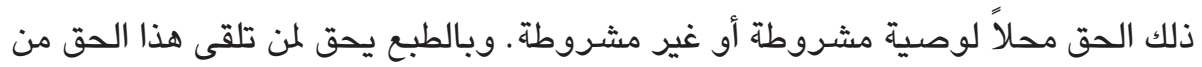

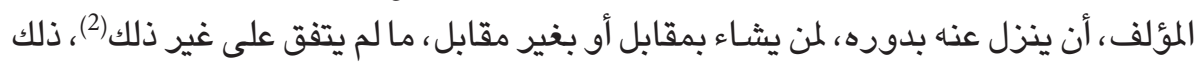

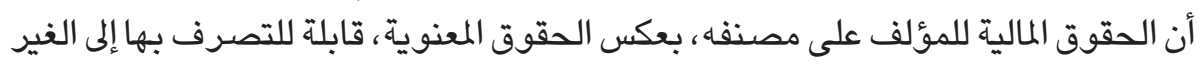
كما سبق القول.

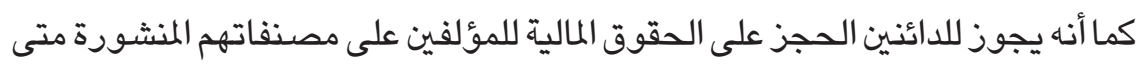

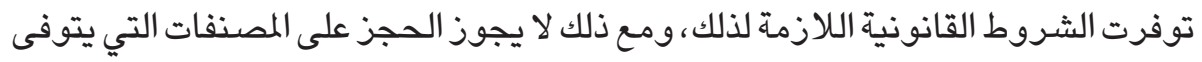

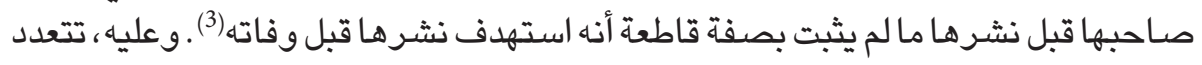

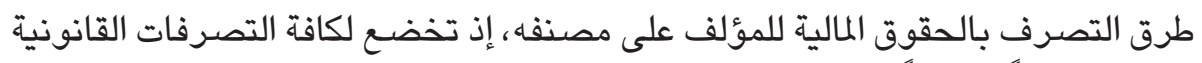
الجائزة شرعاً وقانوناً.

ويلاحظ أن محل التصرف في عقد نقل حقوق المؤلف المالية ينحصر في المصنفات

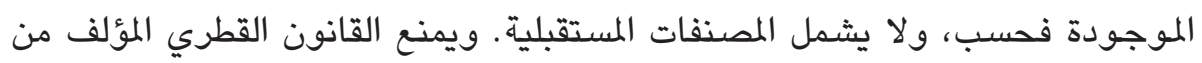

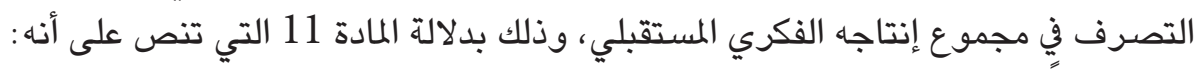

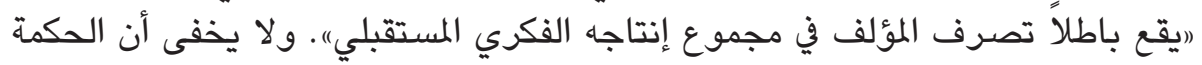

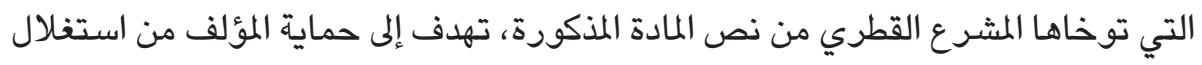

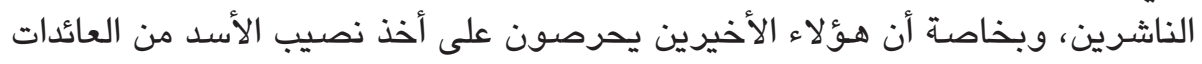

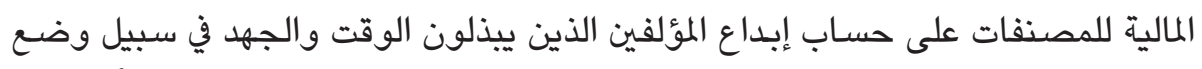

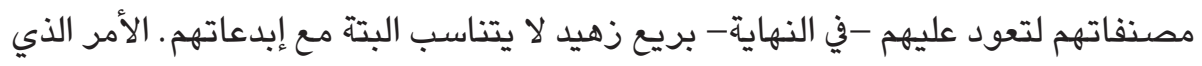
يقتضي شمولهم برعاية الدولة لحمايتهم من ذلك.

(1) (1) المادة 7 و27 من القانون القطري.

(2) مع الأخذ في الاعتبار أنه (الا يعد تنازل المؤلف عن النسخة الأصلية للمصنف تنازلاً عن حقوقه كمؤلف)، المادة 12

من القانون القطري.

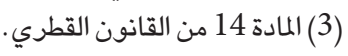




\section{الفرع الثاني \\ أبرز طرق نقل حقوق المؤلف المالية}

يعد عقد النشر من أكثر الوسائل الدارجة في نقل حقوق المؤلف المالية إلى الغير(1). فما هو

عقد النشر ؟وما هي خصائصسه ؟ وما هي آثاره ؟

1- تعريف عقد النشر:

لم يعرف القانون القطري عقد النشر ، وإنما اكتفى بتحديد معالمه الرئيسية، إذ اشترط

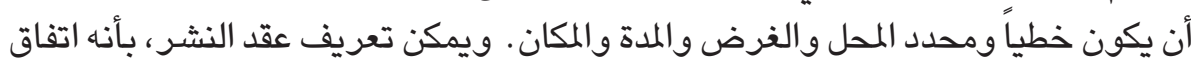

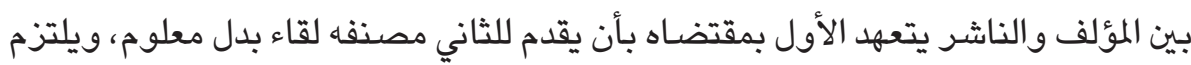

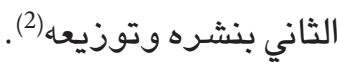

2- خصائص عقد النشر:

يتصف عقد النشر بخصائص عدة، ومن أبرزها الآتي:

أ- عقد شكلي: تشترط بعض قوانين حماية حق المؤلف كتابة عقد النشر كشرط لصحة التصرف، وقد اشترط القانون القطري كتابة عقد نقل الحقوق المالية للمؤلف.

ب- عقد ملزم للجانبين: ذلك أنه ينشأ التزامات متقابلة في ذمة كل طرف من طرفيه (المؤلف والناشر) حسب ما يتم بالاتفاق بينهما.

ت- عقد تبادلي: ذلك أنه يترتب عليه التزامات متبادلة بين المؤلف والناشر ويصورة

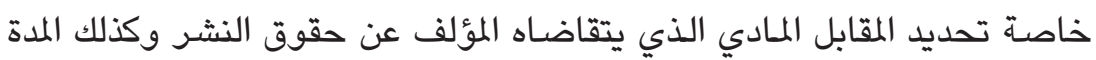
الزمنية.

ث- عقد مختلط: ذلك أنه عقدّ مدنيّ لجهة المؤلف وعقدّ تجاريٌ لجهة الناشر. ج- عقد مستمر: ذلك أنه يستمر لمدة زمنية معلومة ، ثلاث سنوات أو خمس أو نحو ذلك، ولك وينتهي بعدها.

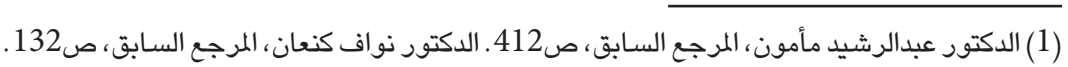

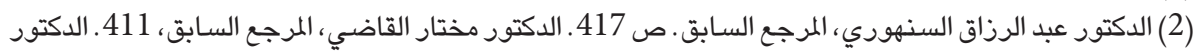

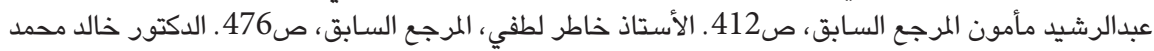

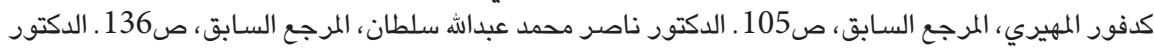
محمد حسن عبدالله، المرجع السابق ، ص298. 


\section{ح- عقد محدد: ذلك أن محله محدد من وقت انعقاده، وليس احتمالياً.} خ- عقد خاصِ: ذلك أنه يخضـع في أحكامه لقانون حماية حق المؤلف أولاً، ثم للقانون المدني ثانياً.

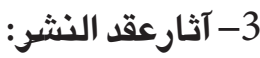

يرتب عقد النشر آثاراً في ذمة أطر افه (المؤلف والناشر)، ومن أبرز ما يلتزم به المؤلف بموجب

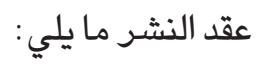
أ- أن يقوم بتسليم المصنف موضوع العقد للناشر. ب- أن يقوم بتصحيح المصنف بعد طباعته خلال مدة معقولة. ت- عدم استغلال المصنف بصورة تلحق ضرراً بحقوق الناشر. ث- ضمان عدم وجود حق وقع على المصنف لطرف ثالث. ج- الامتناع عن أي عمل من شـأنه تعطيل استغلال الحق محل التصرف. وفي المقابل، فإن من أبرز ما يلتزم به الناشر بموجب عقد النشر ما يلي :

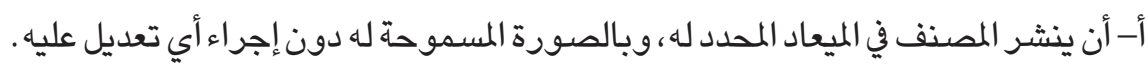

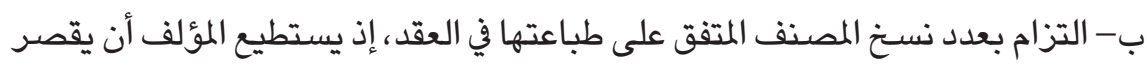

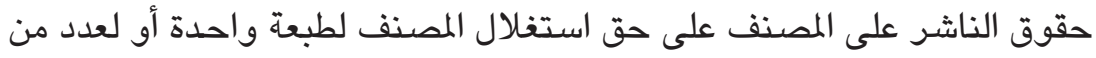

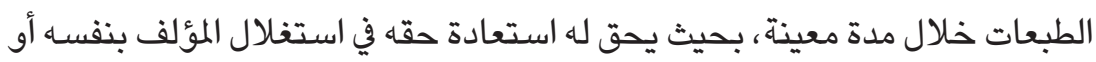
عن طريق ناشر آخر لدى انتهاء العقد الأول. ث- التقيد بعدم استخدام المصنف لغير الغرض المتعاقد عليه. ج- التوقف عن النشر عند انتهاء المدة المتفق عليها في العقد. ح- عدم التنازل عن نشر المصنف لناشر آخر. خ - التعريف بالمصنف محل عقد النشر من خلال وسائل الإعلان وتوزيعه. د- التقيد بالسعر المحدد للنسخة الواحدة من المصنف المتفق على نشره. ذ- دفع المقابل المتفق عليه في العقد للمؤلف. ر- تقديم ما يثبت صحة مبيعات نسخ المصنف والعائد من ذلك، عندما يطلب منه ذلك. 
ومن المعلوم أنه يحق للمؤلف أو خلفه، أن يتقاضى البدل أو المقابل النقدي أو العيني

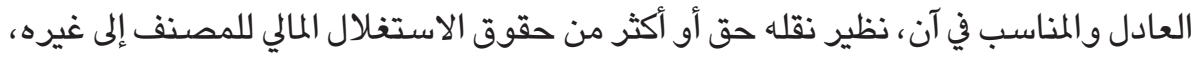

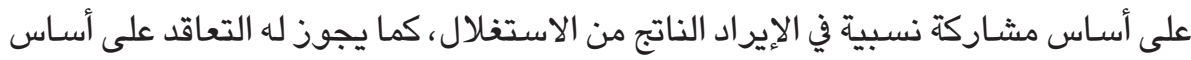

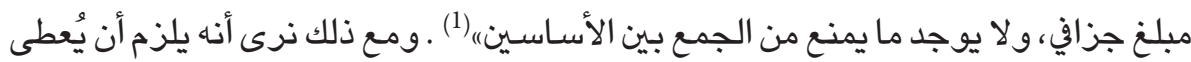

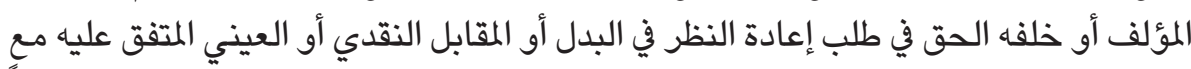

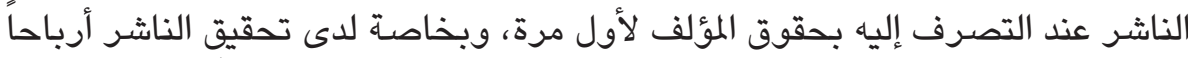

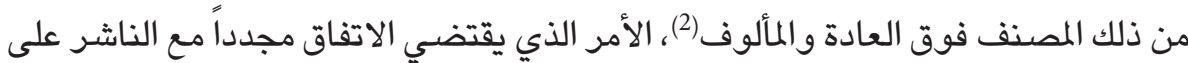

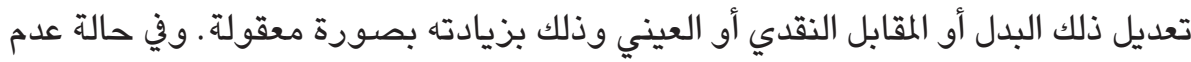

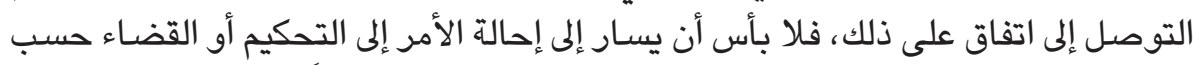

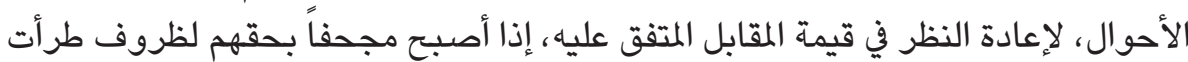

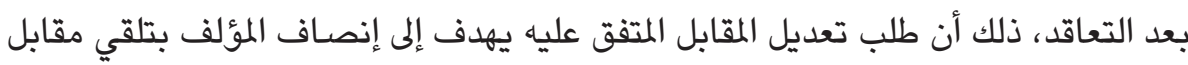
عادل عند تبدل الظروف (3).

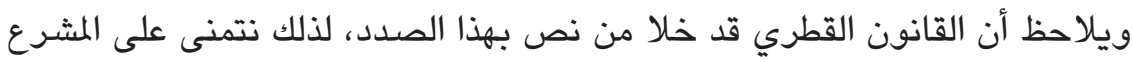

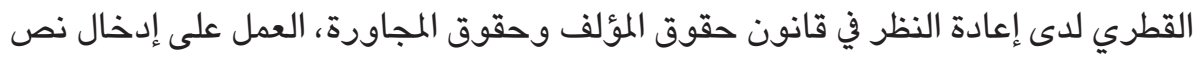
صريح يعالج هذه المسألة(4).

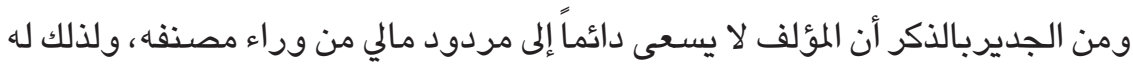

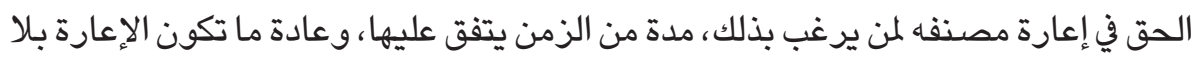
(1) ولعل نظرة سريعة على نماذج عقود النشر الدارج العمل بها لدى دور النشر في غالبية الدول العربية، تبين أن مقدار

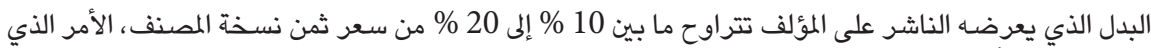

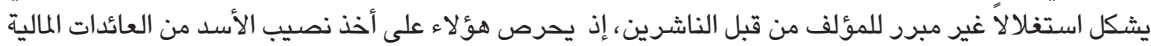

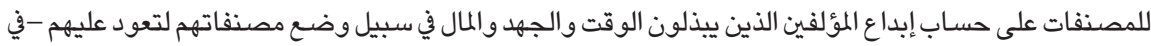

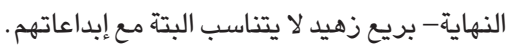

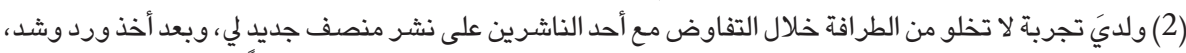

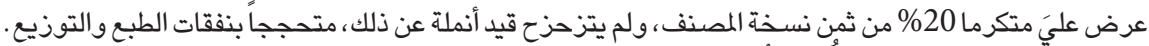

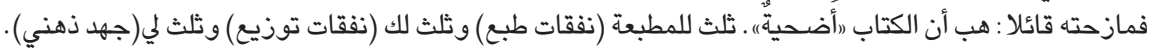

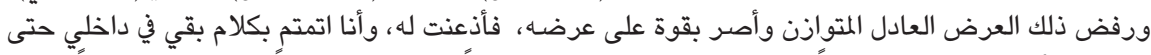

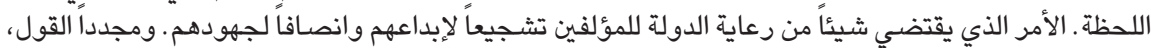

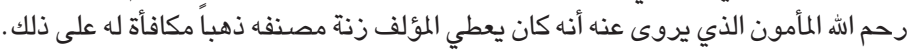

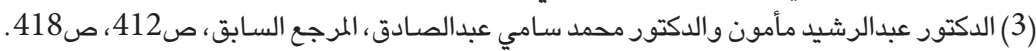

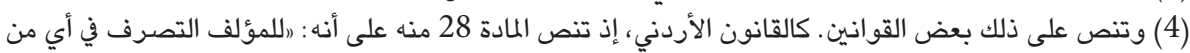

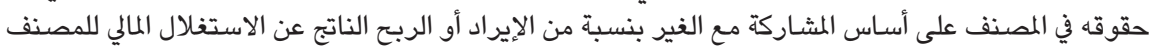

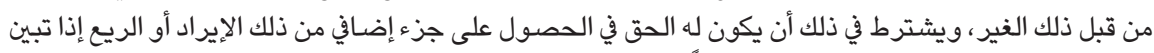

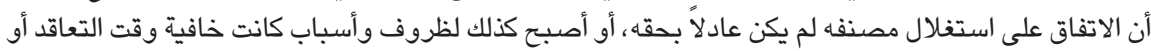
طرأت بعد ذلك. 
مقابل مادي، أو بدون عوض ، أو أن تكون بمقابل رمزي ـ ومع ذلك تعود الإعارة على المؤلف بمردود معنوي.

\section{الفرع الثالث}

\section{القيود الواردة على حقوق المؤلف المادية}

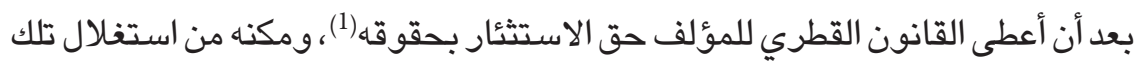

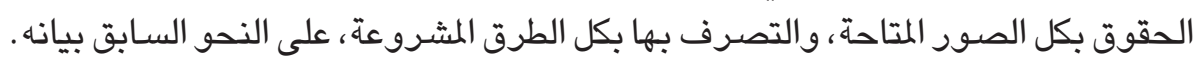

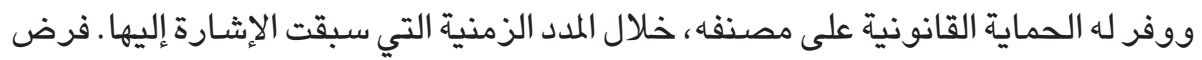

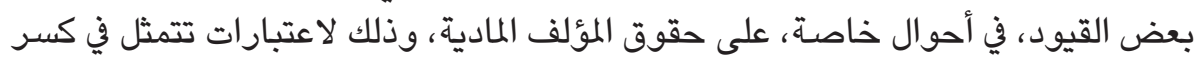

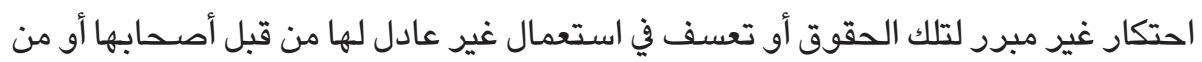

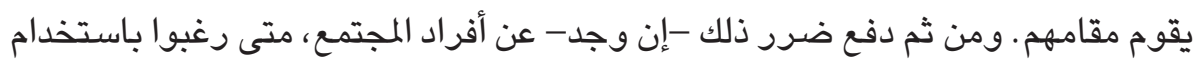

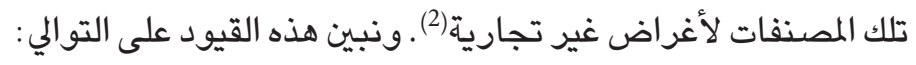

\section{القيد الأول: استعمال المصنف - بلا موافقة المؤلف- بشروط محددة}

يحرص القانون القطري على احترام حقوق المؤلف المعنوية والمالية، كما تقدم البيان.

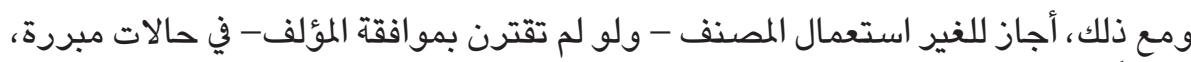

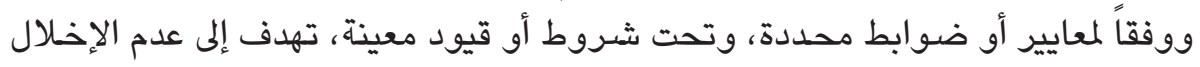
بحقوق المؤلف المعنوية(3) ويمكن رد ذلك إلى مدئ الحالات الآتية (4):

الحالة الأولى: الاستعمالات المشروعة (غير الممنوعة) للمصنفات المحمية لأغراض خاصة

لا يجوز للمؤلف بعد نشر مصنفه أن يمنع أو يعارض الاستعمالات الآتية (5):

1- الاستنساخ أو الترجمة أو الاقتباس أو التوزيع الموسيقي أو التمثيل أو الاستماع الإذاعي

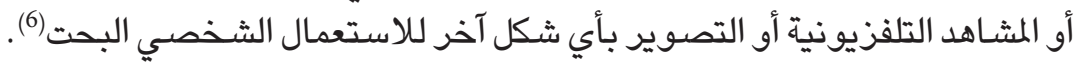

(2) المادة 18 و 19 و 10 من من القانانون القطري.

(3) إذ يشترط ألا يتعارض استعمال المصنف مع الاستفلال العادي له، وألا يسبب ضرراً غير مبرر للمصالح المشروعة للمؤلف. (4) الدكتور محمد حسام محمود لطفي، المدخل لدراسة القانون في ضوء آراء الفقه وأحكام القضاء، القاهرة الطبعة

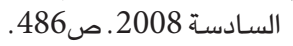
(5) (5) المادة 18 و 20 و23 من من القانون القطري.

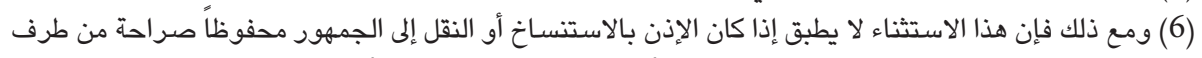

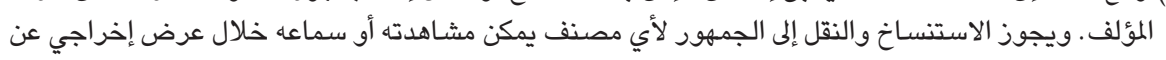




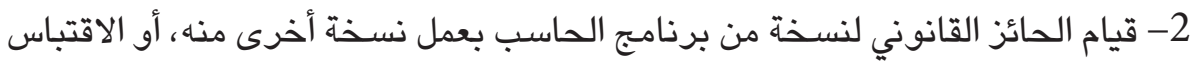

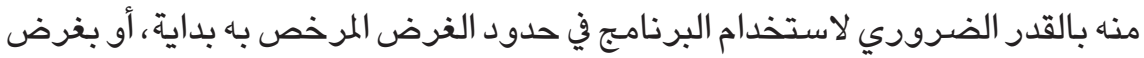

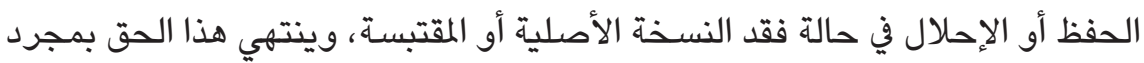
زوال سند الحائز.

3- قيام أي شخص طبيعي بأن يستورد لنفسه نسخة من المصنف، بشرط أن يكون ذلك لأغراض شخصية.

الحالة الثانية- الاستعمالات المشروعة (غير الممنوعة) للمصنقات المحمية لأغراض عامة:

$$
\text { لا يجوز للمؤلف بعد نشر مصنفه أن يمنع أو يعارض الاستعمالات التالية (1): }
$$

1- الاستعانة بالمصنف بهدف الإيضـاح في التعليم، بواسطة المطبوعات أو البرامـج

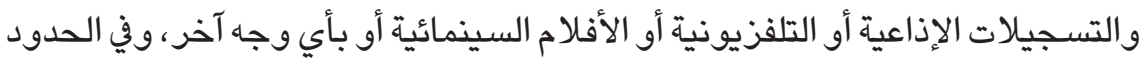

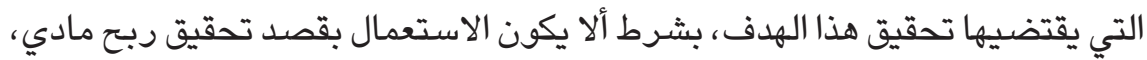
وأن يذكر المصدر واسم المؤلف.

2- الاستشهاد بفقرات من المصنف في مصنف آخر بهدف الإيضاح أو الشرح أو النقد وفي

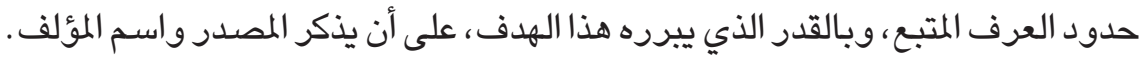

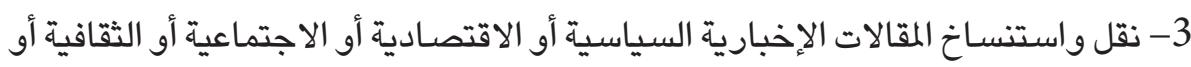

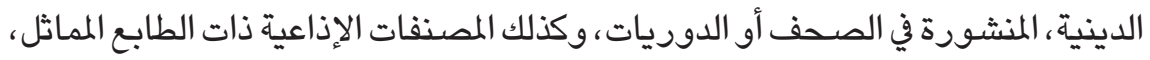

$$
\text { بشرط ذكر المصدر بوضوح واسم المؤلف إن وجد. }
$$

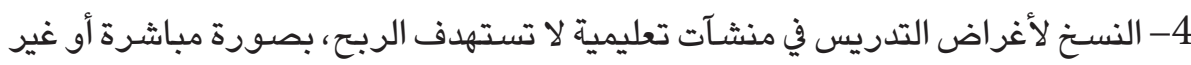

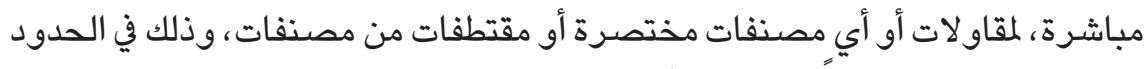

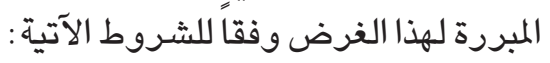

أ) أن يكون النسخخ لمرة واحدة، وإذا تكرر يتم بصورة منفردة في مناسبات متفرقة.

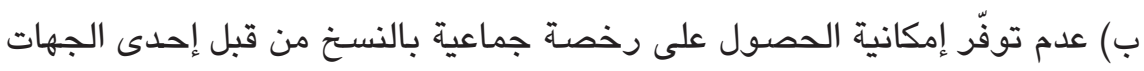

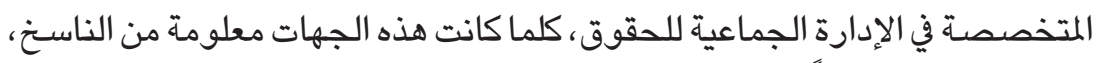
أو يجب أن يكون عالماً بها.

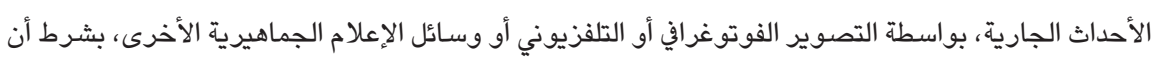

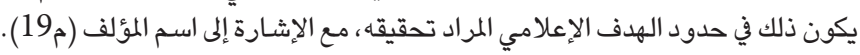

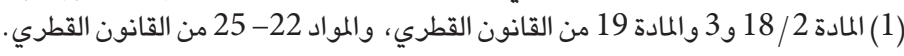




\section{ج) أن يشـار إلى المؤلف وعنوان المصنف على كل النسـخ، كلما كان ذلك ممكناً.}

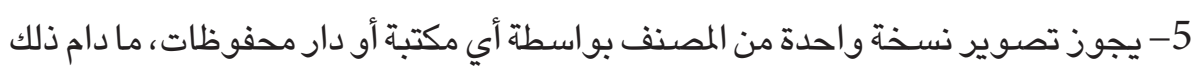

$$
\text { لا يستهذف الربح على النحو الآتي: }
$$

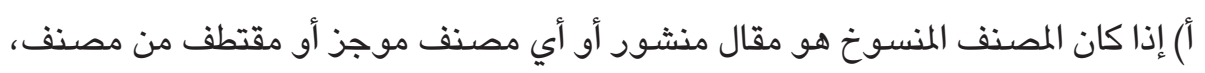
وكان الهدف من النسخ هو تلبية احتياجات شخص هول طبيعي بشرطين الثنين هما:

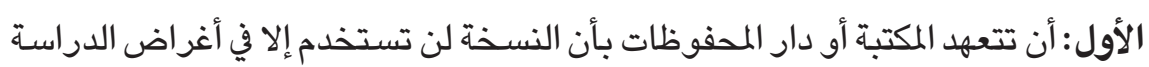

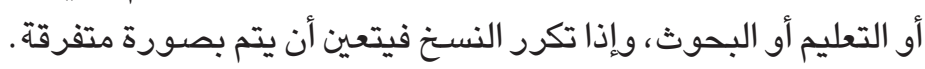

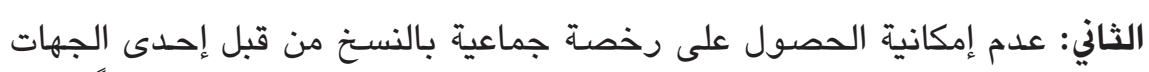

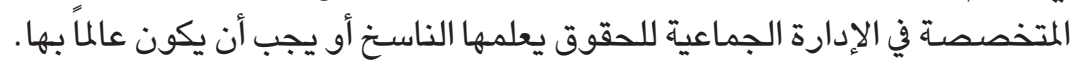

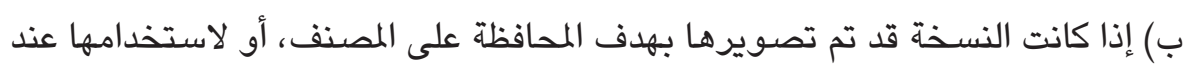

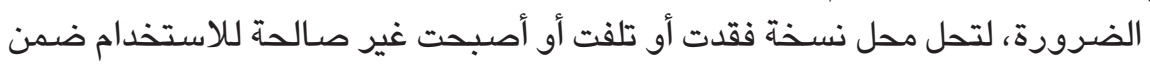
المقتنيات الدائمة لمكتبة أو دار محفوظات أخرى فيمكن استنساخها بشرطين اثنين هما:

$$
\text { الأول: أن يكون مستحيلًا الحصول على هذه النسخة بشروط معقولة. }
$$

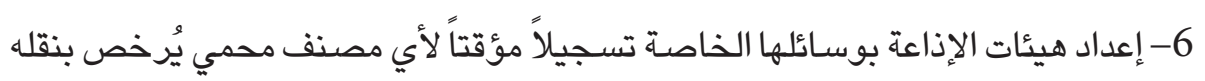

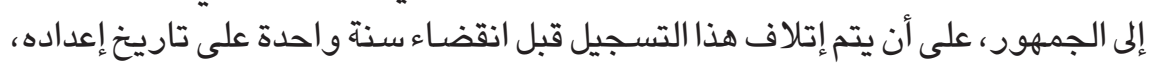

$$
\text { ويستثنى من الإتلاف التسجيلات ذات الطبيعة الوثائقية. }
$$

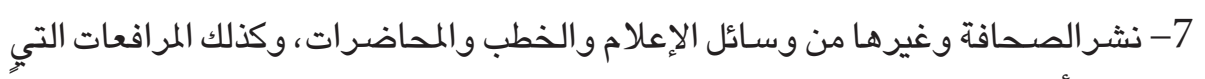

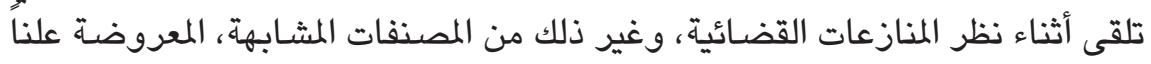

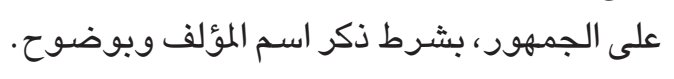

8- استخدام الفرق الموسيقية التابعة للقوات العسكرية، استخدام الإيقاع أو الأداء العلني

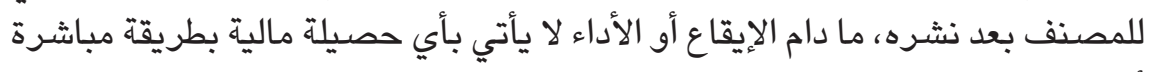

$$
\text { أو غير مباشرة. }
$$

\section{القيد الثاني- حق الحصول على رخصة باستعمال المصنفات:}

يعطي القانون القطري حق الحصول على رخصة باستخدام المصنف في حالتين هما(1): 


\section{الحالة الأولى-ترجمة المصنف:}

ويشترط في هذه الحالة الآتي:

1- أن يكون موضوع الرخصة ترجمة أي مصنف أجنبي منشور إلى اللغة العربية

$$
\text { لغرض نشرها في قطر. }
$$

2- أن يمر ثلاث سنوات على تاريخ أول نشر للمصنف، ولم يتم نشر أي ترجمة له

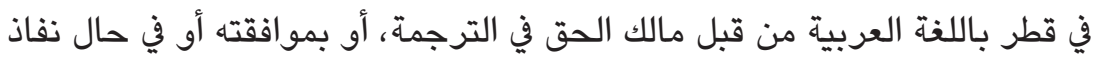

$$
\text { الطبعات المترجمة حسب واقع الحال. }
$$

3- أن يكون طالب الرخصة مواطناً قطرياً.

4- أن تكون الرخصة غير حصرية.

5- أن تكون الرخصسة شخصية وغير قابلة للتنازل إلى الغير.

6- أن تكون الترجمة لغايات التعليم المدرسي أو الجامعي أو البحوث.

7- أن يوافق وزير الاقتصاد والتجارة أو من يفوضه على الرخصة.

8- أن تباع النسخة المنشورة موضوع الرخصة بسعر مسـاو ، أو أقل من سعر المصنفات

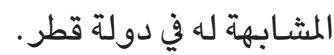

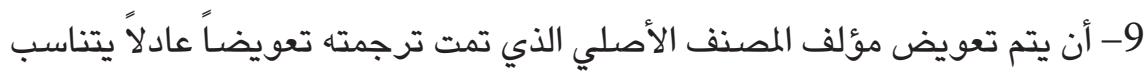

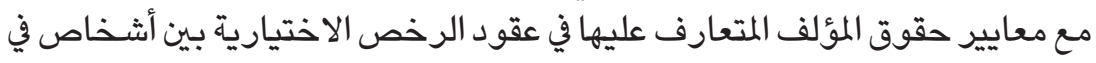
دولة قطر وبين أشخاص في دولة المؤلف.

الحالة الثانية- نسخ ونشر المصنف المنشور:

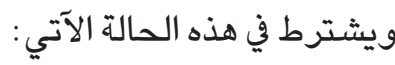

1- أن يكون موضوع الرخصة نسخ ونشر أي مصنف منشور.

2- أن يكون طالب الرخصة مواطناً قطرياً.

3- أن تكون الرخصة غير حصرية.

4- أن تكون الرخصـة شخصية وغير قابلة للتنازل إلى الغير.

5- أن يكون الغرض من النسخخ الاستعمال في إطار التعليم المدرسي أو الو الجامعي.

6- أن يوافق وزير الاقتصـاد والتجارة أو من يفوضه على الرخصـة. 


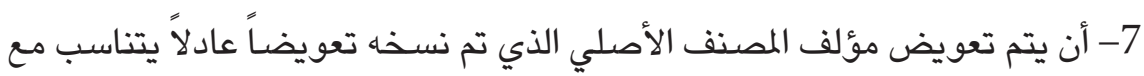

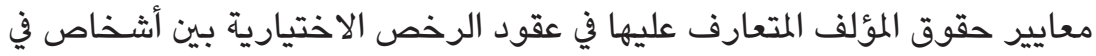
دولة قطر وبين أشخاص في دولة المؤلف.

8- مرور ثلاث سنوات على تاريخ أول نشر لأي مصنف مطبوع يتعلق بالتكنولوجيا

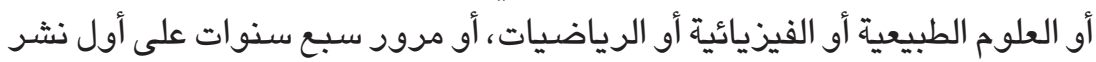

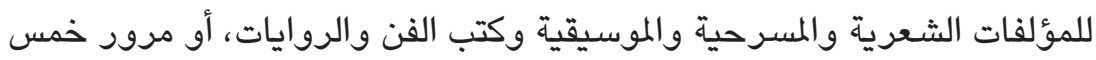
سنوات على أول نشر لأي مصنفات مطبوعة أخرى .

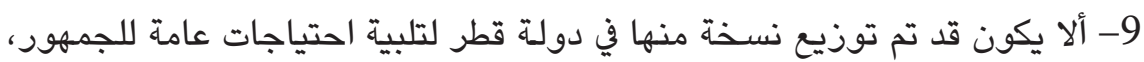

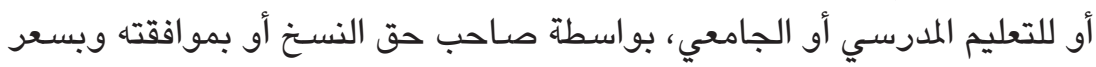

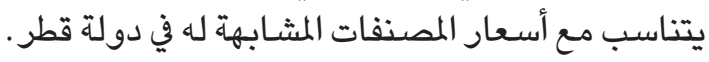

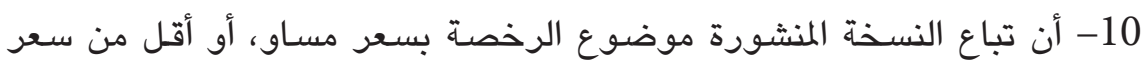

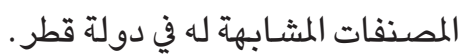

ويلاحظ أن محل الرخصة تنحصر في ترجمة المصنف أو نسخه، ، ومع ذلك لا يوجد ما

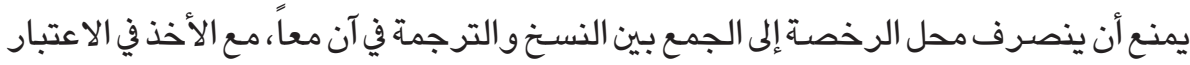

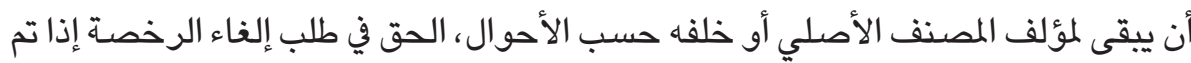

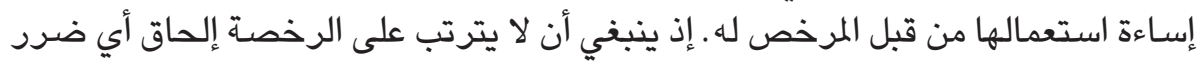

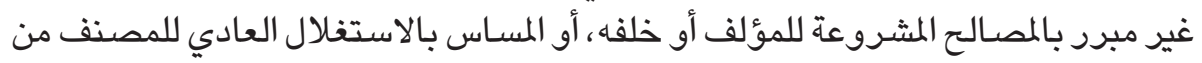
قبل صاحب الحق في ذلك.

القيد الثالث- شرط الحصول على إذن أو موافقة صاحب الشأن: يشترط القانون القطري الحصول على إذن أو موافقة صاحب الشـأن قبل نشر ما يتعلق بهذا الأخير ، ومن قبيل ذلك الآتي:

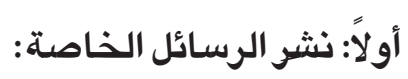

أعطى القانون القطري للمؤلف حق نشر رسائله الموجهة إلى آخرين دون إذن منهم،

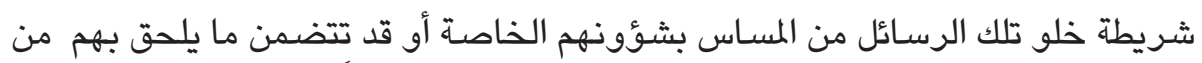

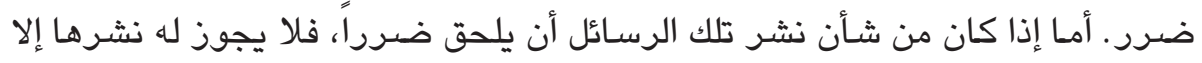

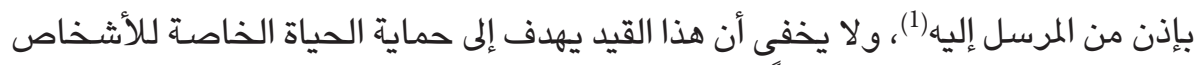

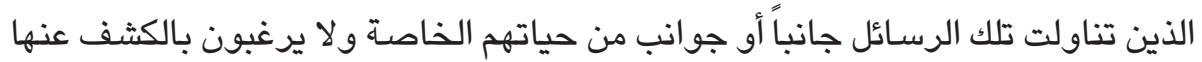

(1) (1) (المادة 13 من القانون القطري. 
للعموم؛ لذا لا يجوز للمؤلف نشر تلك الرسائل دون إذن المرسل إليهم، إذا كان من شأن

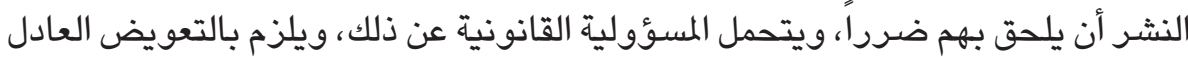
متى توافرت شروطه.

ثانياً: نشر الصور الخاصة:

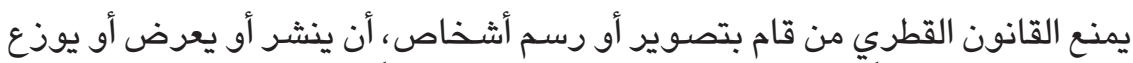

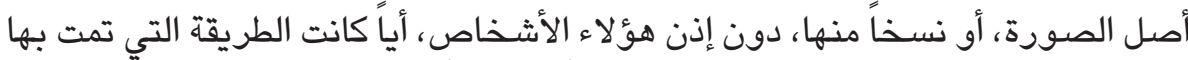

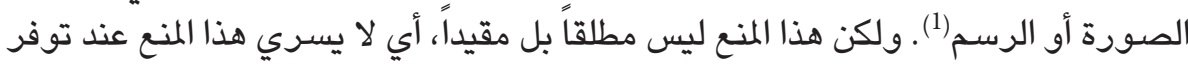
الشروط التالية: - (الية 1- إذا كانت الصورة أو الرسم قد تم بمناسبة حوادث وقعت علناً. 2-2 إذا كانت الصورة أو الرسم تتعلق بأشخاص ذودي صفة رسمية. 3- إذا كانت الصورة أو الرسم تتعلق بأشخاص يتمتعون بشهرة عالمية. 4- إذا سمحت السلطات العامة بالصورة أو الرسم خدمة للصـالح العام.

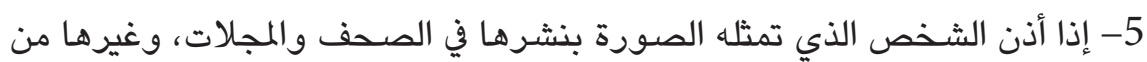
النشرات المماثلة، حتى ولو لم يأذن بذلك المصور ، ما لم يوجد اتفاق على غير ذلك.

\section{الفرع الرابع}

\section{أحكام المصنف بعد وفاة المؤلف}

خصص القانون القطري المواد 28 إلى 31 منه، لبيان أحكام المصنف بعد وفاة المؤلف. ونعرج على هذه المواد المذكورة للوقوف على ما جاء بها من الأحكام على التوالي. أولاًَ- طرق انتقال حقوق المؤلف:

تحدد هذه الطرق، المادة 28 من القانون القطري، والتي تنص على أن: (هقوق المؤلف

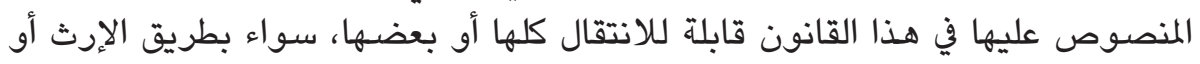

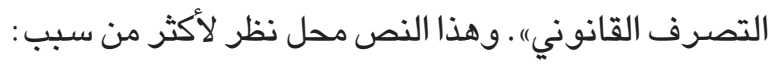
السبب الأول: إن النص المذكور يقضي بـأن: (رقوق المؤلف قابلة للانتقال كلها أو (1) (1) (المادة 14 من القانون القطري. 
بعضها)، الأمر الذي يعني أن حقوق المؤلف بشقيها المعنوية والمالية على حد سواء كلها أو

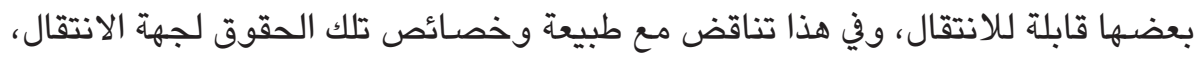
ذلك أن حقوق المؤلف المادية - دون الحقوق المقان لمنوية- تقبل الانتقال(1).

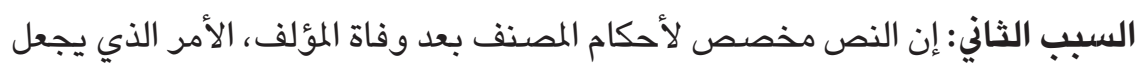

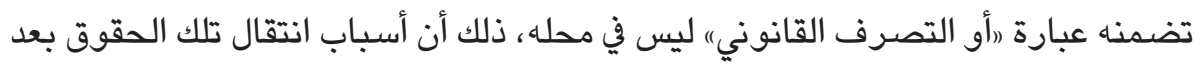

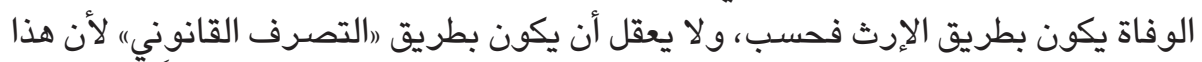

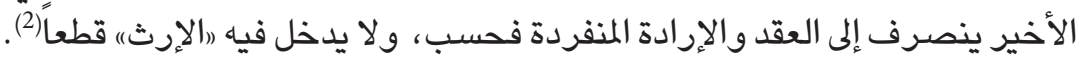

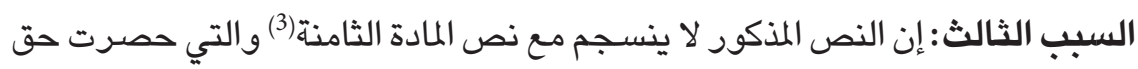

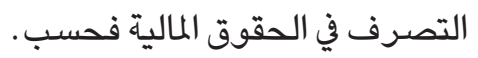
السبب الرابع: إن النص المذكور يتعارض مع القاعدة القائلة ببطلان التصرف بالحقوق

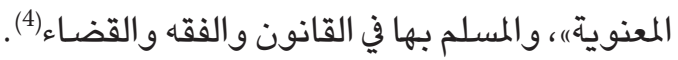

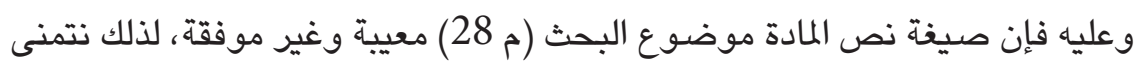

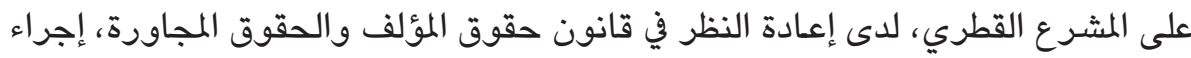
تعديل على نص المادة المذكورة بصورة إعادة المرفع ما فاعتون اعتوره من عيوب صياغته المنوه عنها.

\section{ثانياً - وصية المؤلف بمنع نشر مصنفه أو تعيين موعد لنشره:}

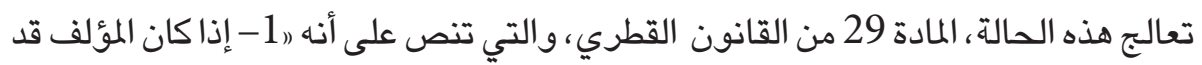

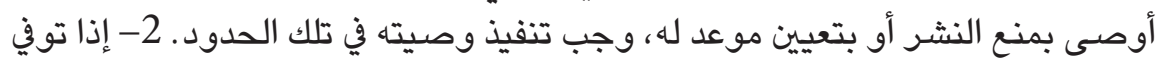

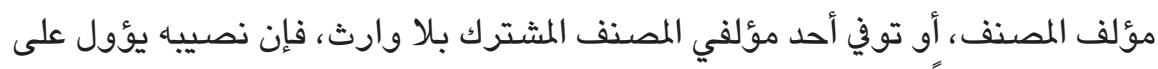

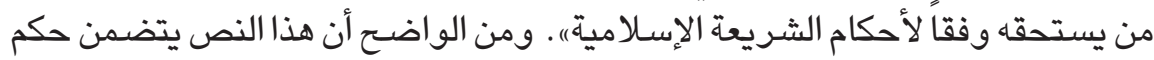

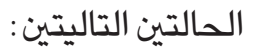

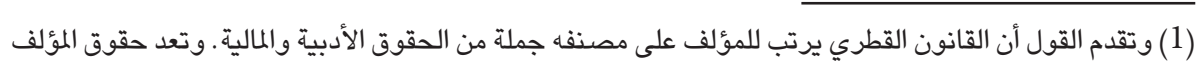

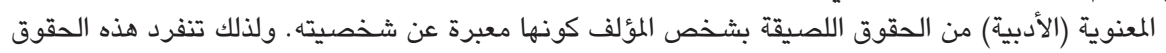

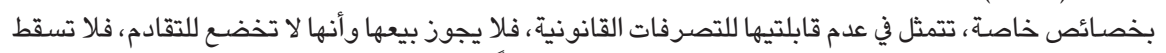

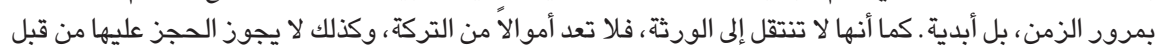
الدائنيين، فلا تعد من الذمة المالية.

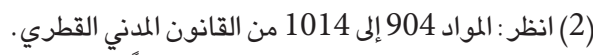

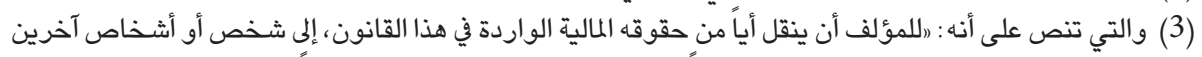

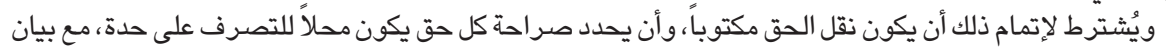

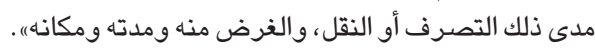

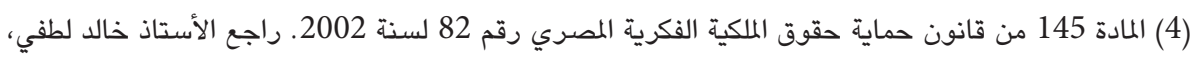

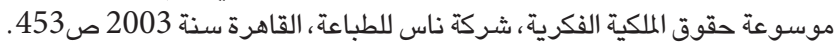


الحالة الأولى: حالة وجود وصية من المؤلف بمنع النشر أو بتعيين (تحديد) موعد له.

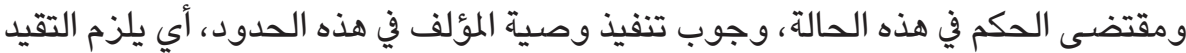

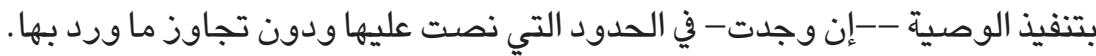
الحالة الثانية: حالة وفـاة مؤلف المصنف أو أحد مؤلفيه دون أن يكون له وارث. ومقتضى الحكم في هذه الحالة، وجوب انتقال نصيب المؤلف المتوفى إلى من يستحقه وفقاً لأحكام الشريعة الإسلامية.

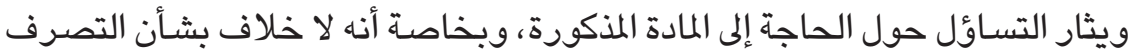

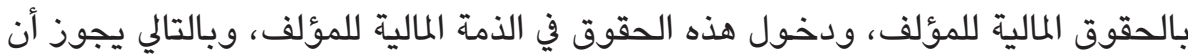

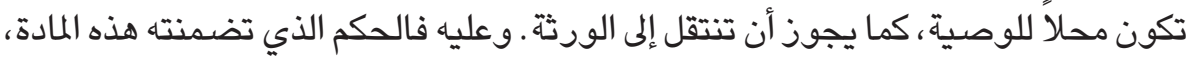

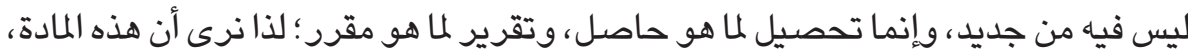
بفقرتيها، تزيد لا لزوم له، لأن أحكام الوصية وقلما وقواعد الميراث تغني عن ذلك.

ثالثاً - نشر مصنف المؤلف المتوفى : تأن

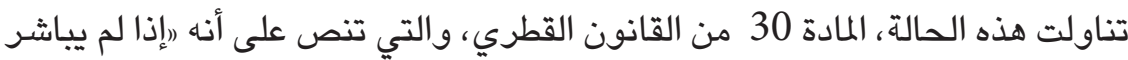

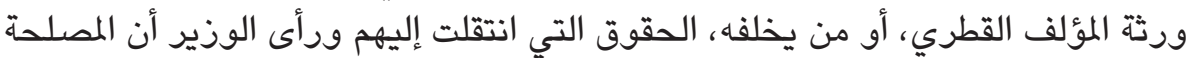

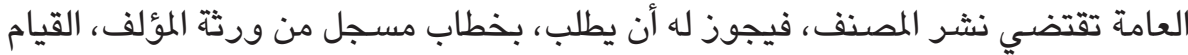

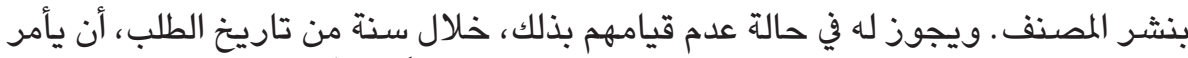
بنشر المصنف، على أن يعوض الورثة في هذه الحالة تعويضاً عادلاًا).

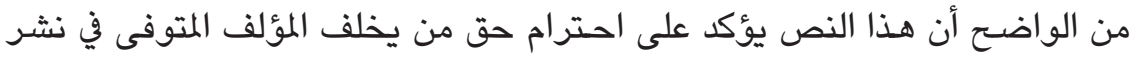

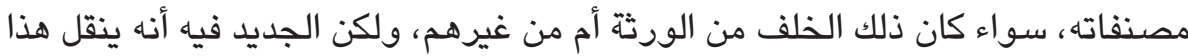
الحق للوزير ليتولى ذلك، وفقا للشروط الآتية :

1- أن يكون المصنف عائداً لمؤلف قطري، ويتقاعس ورثته أو من يخلفه عن نشر ذلك المصنف. 2- أن تقتضي المصلحة العامة نشر ذلك المصنف. 3- أن يطلب الوزير بخطاب مسجل من ورثة المؤلف أو من يخلفه القيام بنشر ذلك المصنف، ولم يبادروا إلى نشر ذلك المصنف خلاب من من ونة من تاريخ الطلب. 4- أن يتم تعويض الورثة تعويضًاً عادلاً.

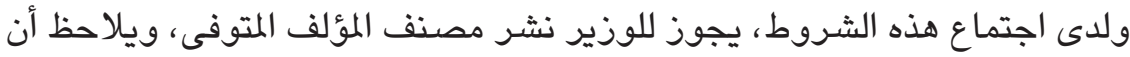

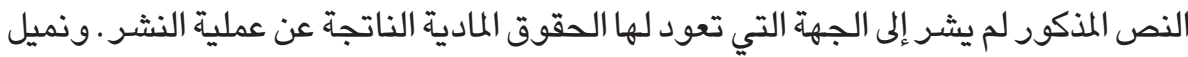
إلى القول أن تلك الحقوق يجب أن تكون للدولة متى تم النشر من قبل الوزير. 


\section{رابعاً- المصنفات التي تُنششر لأول مرة من قبل ورثنة المؤلف بعد وفاته:}

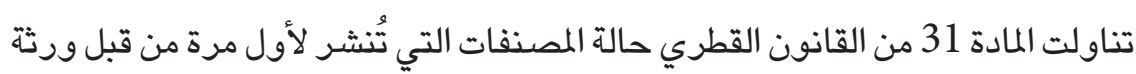

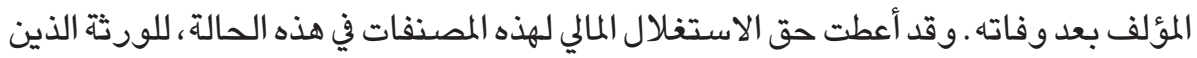

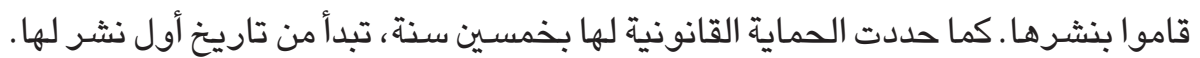

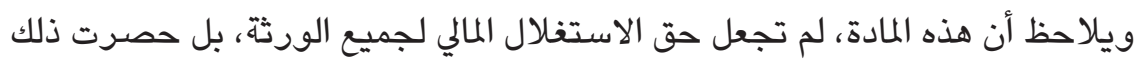

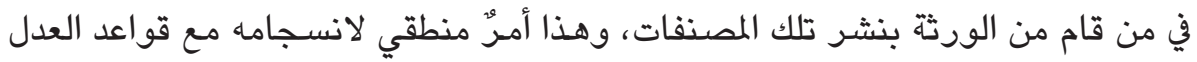
و الإنصاف.

\section{المطلب السادس}

\section{الحماية القانونية لحقوق المؤلف}

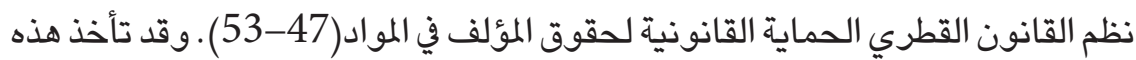

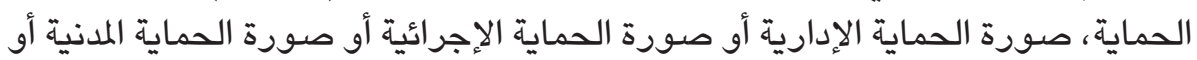

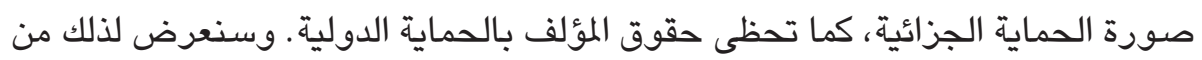

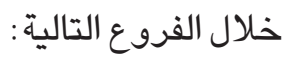

\section{الفرع الأول \\ الحمايـة الإداريـة}

تتمثل الحماية الإداريـة بنظام إيـاع أو تسجيل المصنف لدى الجهة المختصـة وفقاً

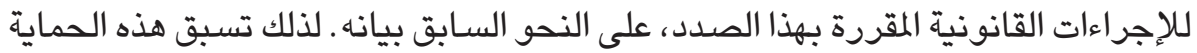

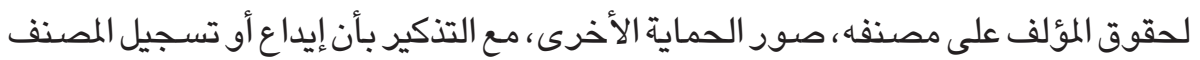

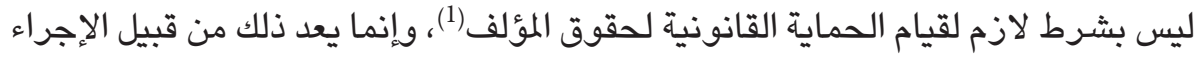

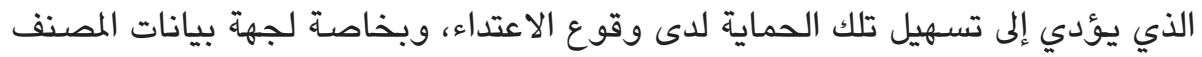

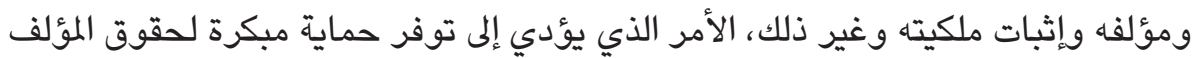

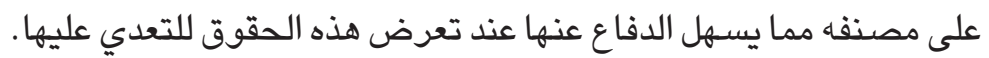
(1) الدكتور حسن جميعي، مدخل إلى حقوق المؤلف والحقوق المجاورة، القاهرة 10 أكتوبر2004 من منشورات

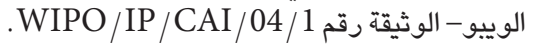




\section{الفرع الثاني \\ الحماية الإجرائية}

تتمثل الحماية الإجرائية في جملة من الإجراءات التي يحق للمحكمة المختصة أن تأمر

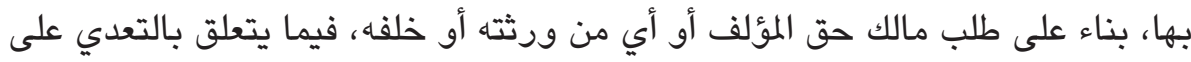

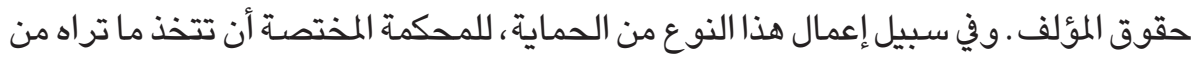

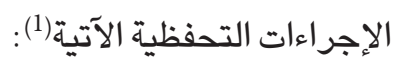

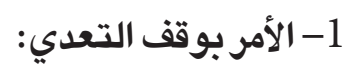

يقتضي هذا الإجراء تحديد المصنف محل التعدي تحديداً تاماً، وتأمر المحكمة المختصة المدية

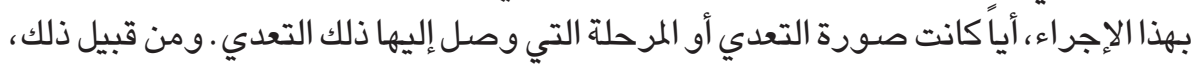

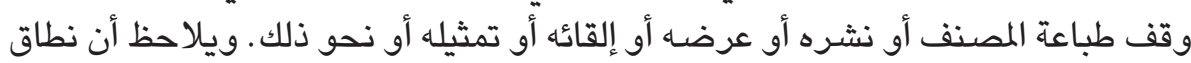

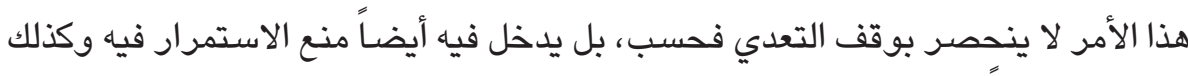
حظره مستقبلاً.

\section{2- ضبط النسخ المخالفة والتحفظ عليها أو أي جزء منها:}

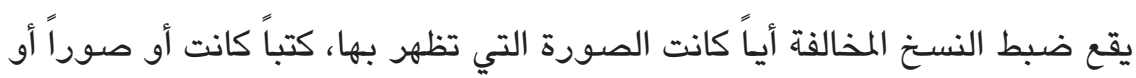

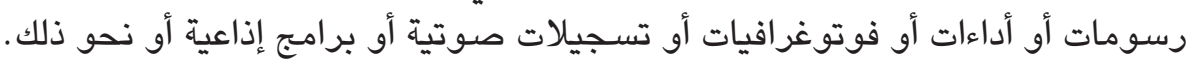

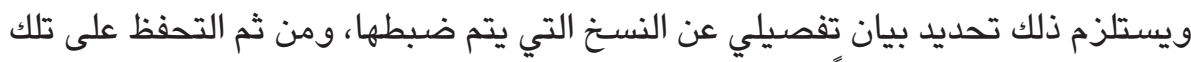

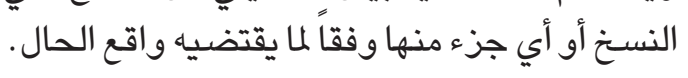

ويلاحظ أن هذا الإجراء مقصور على النسخ المخالفة فحسب، ولا لإيشمل النسخ الأصلية

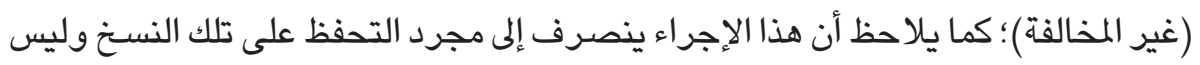
إلى توقيع الحجز عليها.

3- مصادرة النسخ المخالفة أو أي مواد استعملت في الاستنساخ:

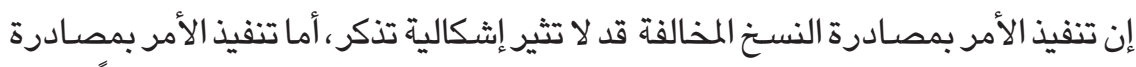

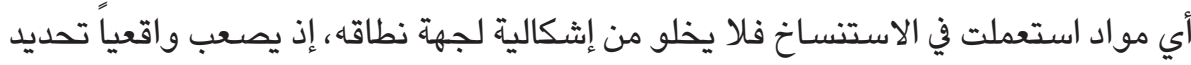

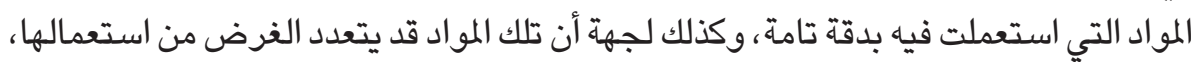

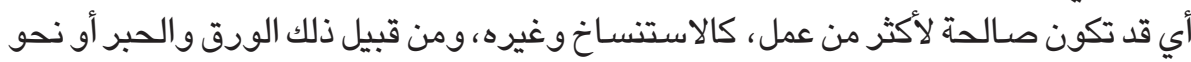

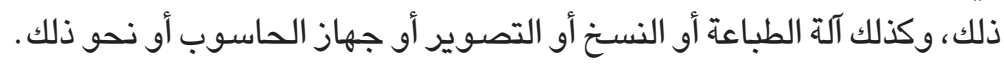

(1) (1) (المادة 47 من القانون القطري. 
و عليه يمكن القول أن عبارة (أي مواد استعملت في الاستنساخ) تحتاج إلى ضبط وتحديد

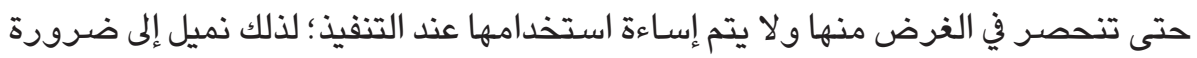
تقييد تلك المواد بعدم قابليتها لغير عمل الاستنساخ. 4- الحكم بالتعويض المناسب:

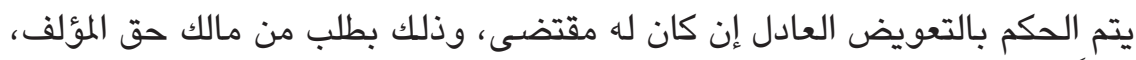

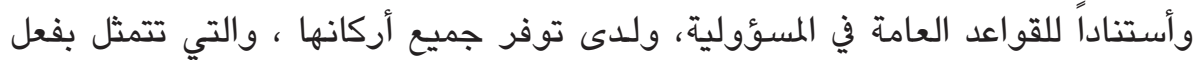

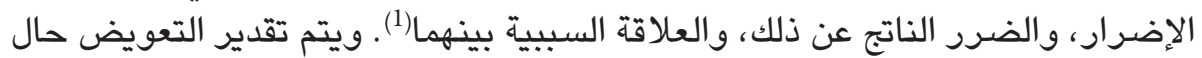

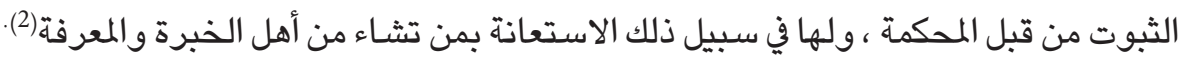
5- مصادرة عائدات الاستغلال الناتجة عن المخالفة:

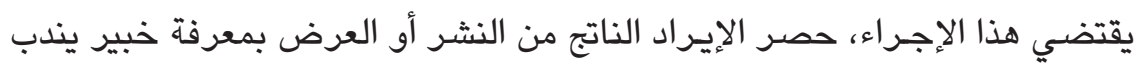

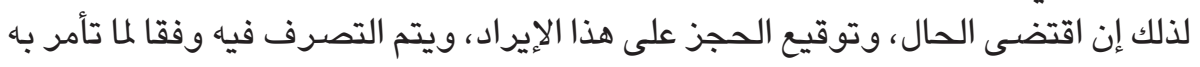

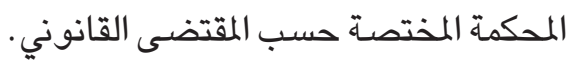

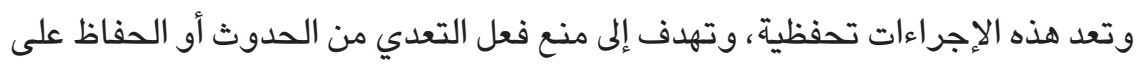

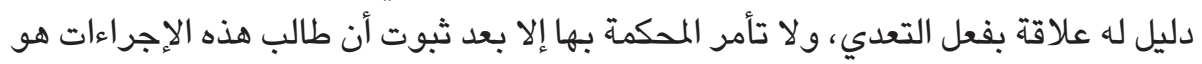

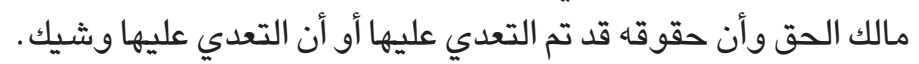
ويلاحظ أن القانون القطري قد اشترط ثبوت أن يكون طالب الإجـراءات المذكورة

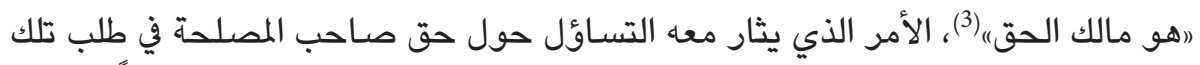

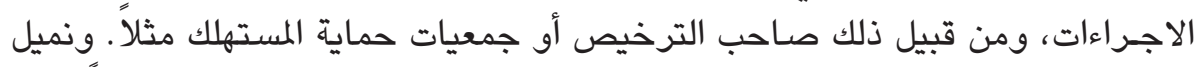

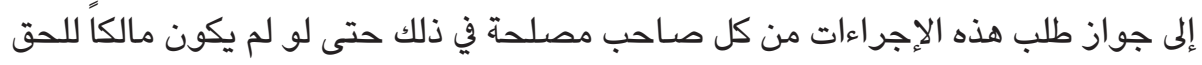

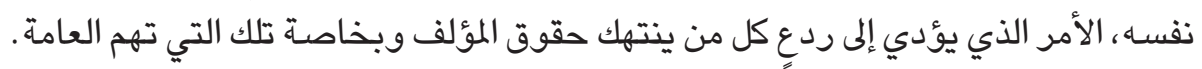

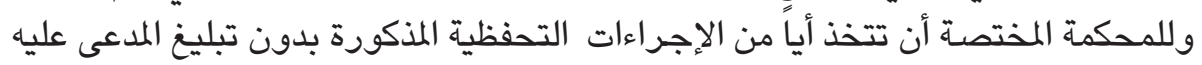
وفي غيابه، وذلك في الحالات الآتية(4):

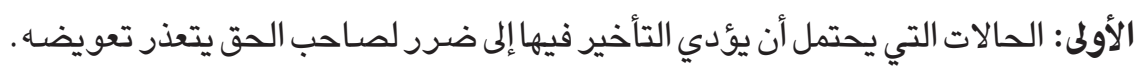
الثانية: الحالات التي تكون فيها خطورة ضياع أدلة متعلقة بفعل التعدي.

$$
\text { (1) الدكتور عدنان سرحان، المرجع السابق، ص93 (12) }
$$

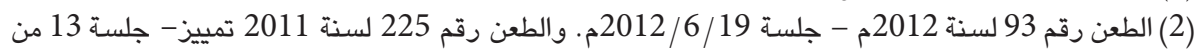

$$
\text { مارس سنة 2012م. }
$$

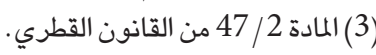
(4) ( المادة 3 / الماد /47 من القانون القطري. 
وفور تنفيذ الإجراء، يتم تبليغ وإطلاع الأطراف المتضررة بالإجراءات التحفظية المتخذة

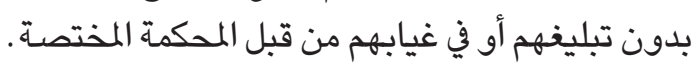

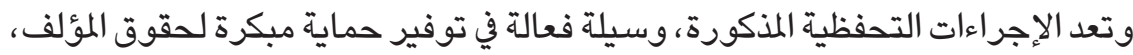

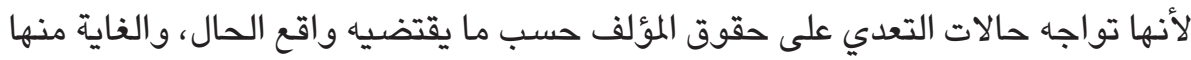

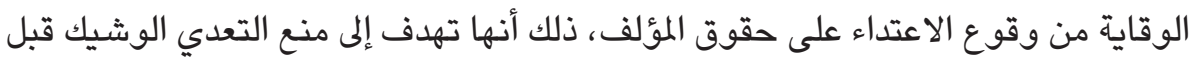

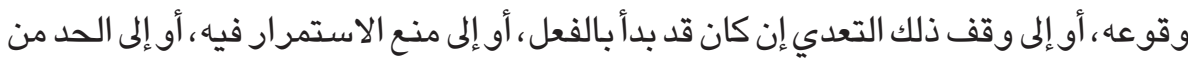

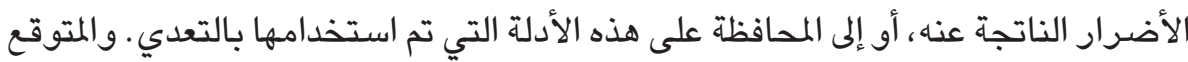

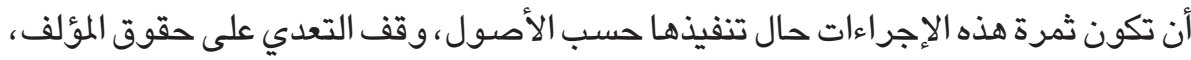

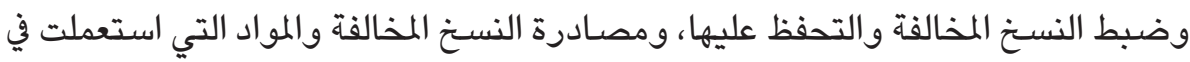

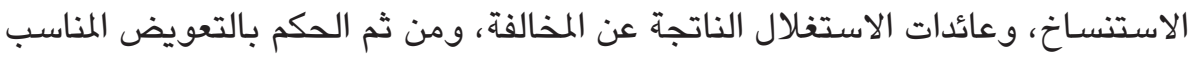

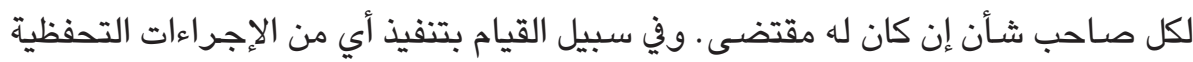

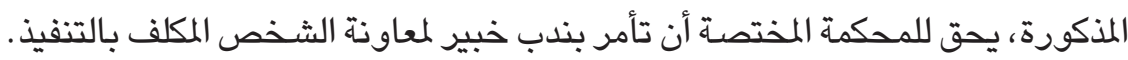
ويجب أن يرفق بطلب أي إجراء من الإجراءات التحفظية المذكورة، كفالة مالية كافية،

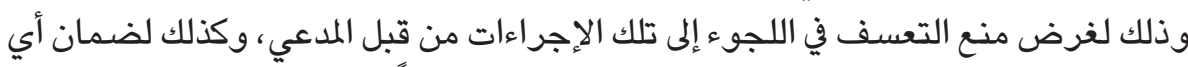

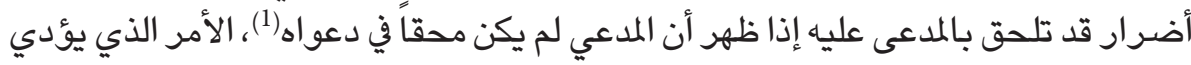

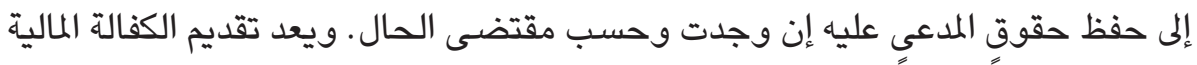

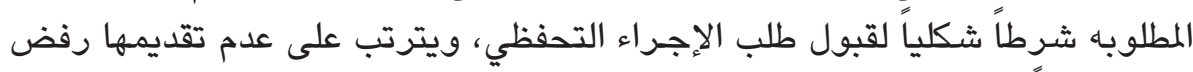
الطلب شكلاً.

ويحق للمدعى عليه أن يطلب من المحكمة، إلغاء الإجراءات التحفظية المتخذة ضدهاه،

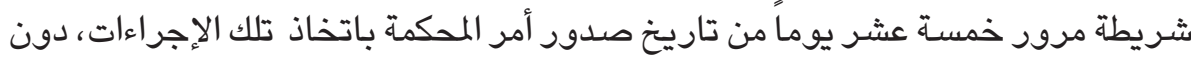

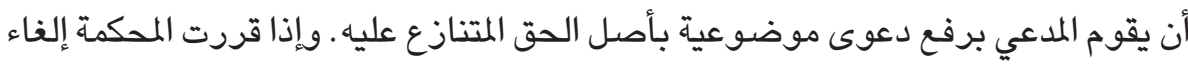

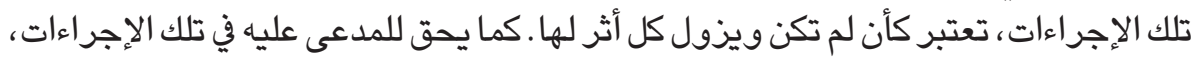

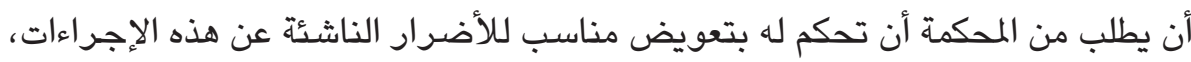

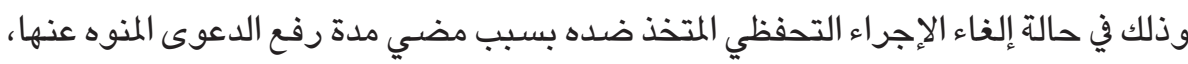

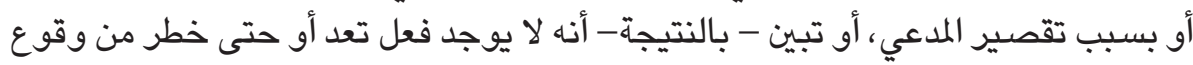

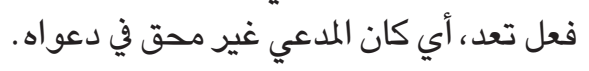

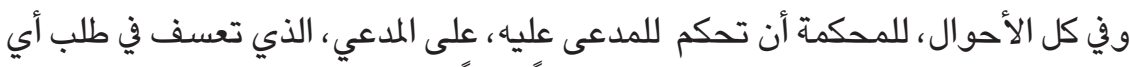

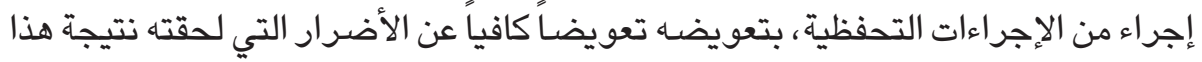

(1) (1) (المادة 47 / 47 من القانون القطري. 


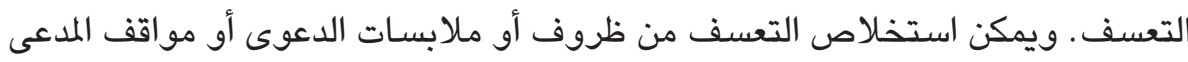

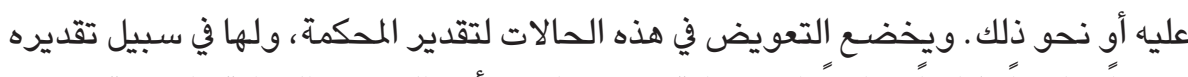

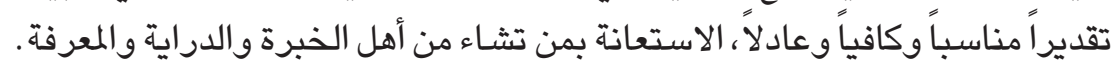

\section{الفرع الثالث}

\section{الحمايـة المدنية}

يتم ممارسـة الحماية المدنية من خلال الدعوى المدنية(1). وتستتد هذه الأخيرة للقواعد العامة في المسؤوليةّ(2)، والتي تقضي بـأن : (اكل خطأ سبب ضسراً للغير يلزم من ارتكبه بالتعويض)|(3)، الأمر الذي يعني ضرورة توفر ثلاثية شروط هي : الخطأ والضرر والعلاقة

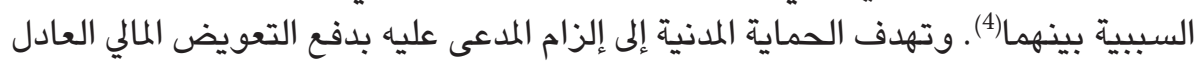

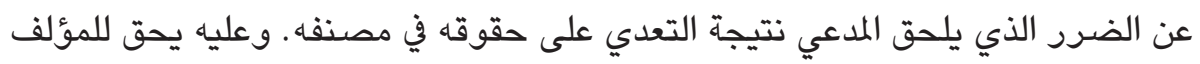
اتباع طريق الحماية المدنية، في حال التعدي على حقوقه في مصنفه، ، ويتم ذلك بإقامة الدعوى

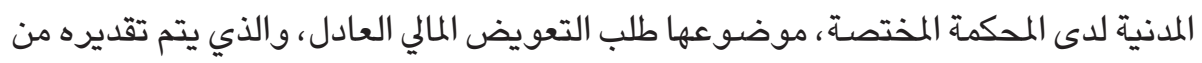
قبل المحكمة، ولها في سبيل ذلك الاستعانة بمن تشـاء من الخبراء في هذا الصدد (5).

\section{الفرع الرابع}

\section{الحمايّة الجنائية}

تعد الحماية الجنائية وسيلة قاسية، ولكنها مبررة، لأنها تهدف إلى زجر وردع ومعاقبة

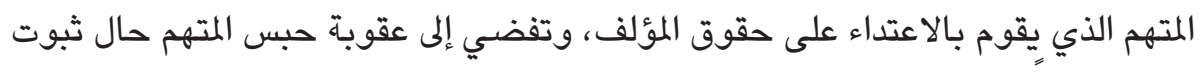
ارتكابه فعلاً يجرمه القانون.

وقد نظم القانون القطري الحماية الجنائية لحقوق المؤلف في المواد 48 - 53 . وقد حددت

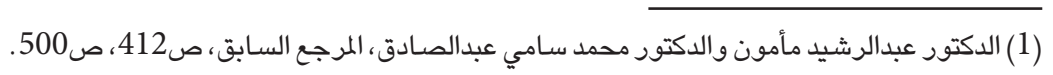

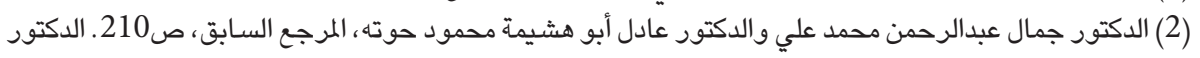

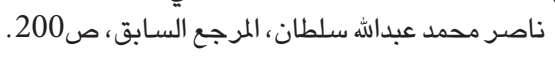

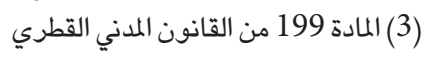

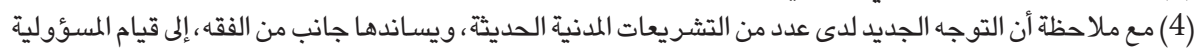

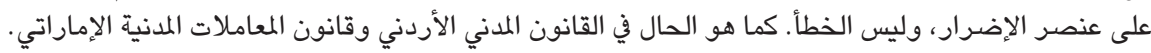

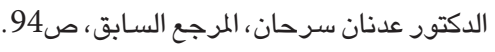

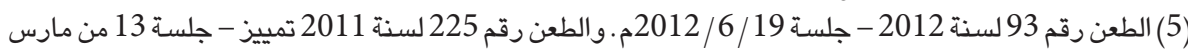


هذه المواد الأفعال التي تشكل تعدياً على حقوق المؤلف أو خرقاً للقانون، ويمكن رد الأفعال المجرمة التي حوتها نصوص المواد الافعاد المذكور إلى الآتي :

1- جريمة استغلال المصنف بدون وجه حق:

تعالج هذه الجريمة حالات الإستغلال غير المشروع للمصنف، ولذلك يعد مرتكباً لهذه

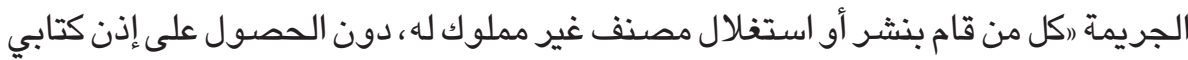

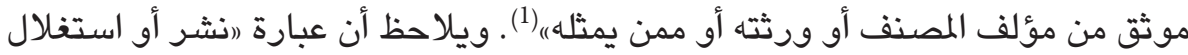

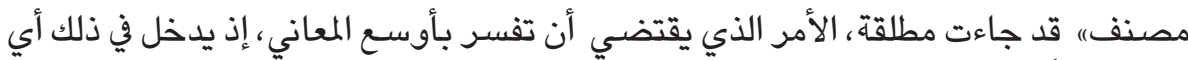

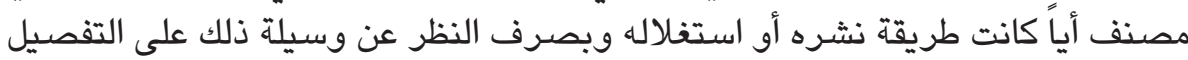

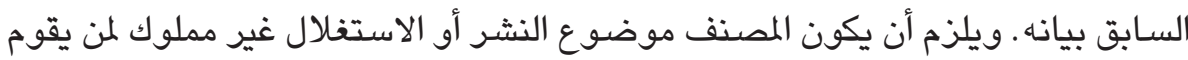

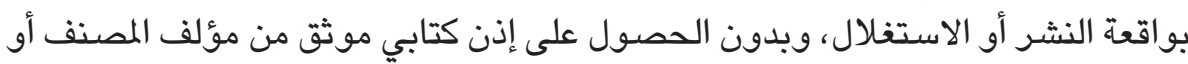

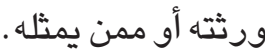

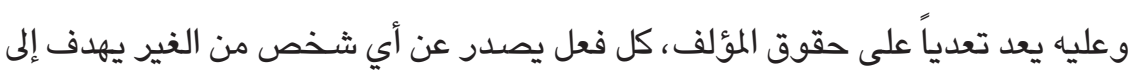

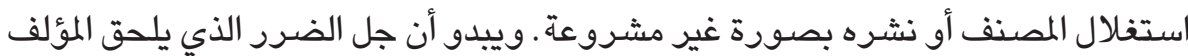

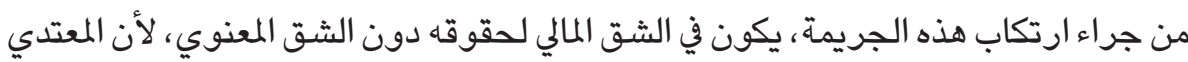

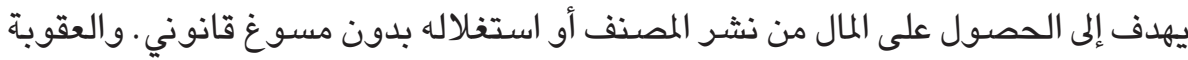

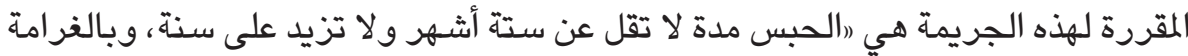

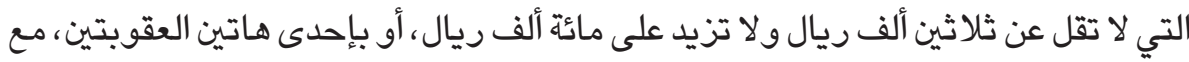

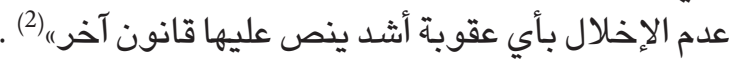

$$
\text { 2- جريمة الادعاء-كذباً - ملكيته المصنف: }
$$

تعالج هذه الجريمة حالات اغتصاب المصنف، ولذلك يعد مرتكباً لهذه الجريمة (ركل

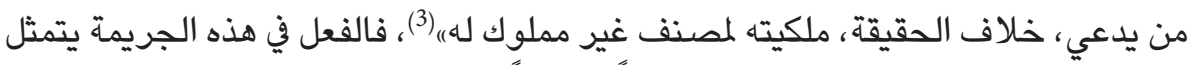

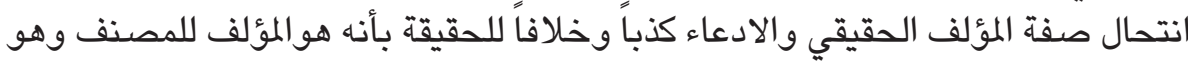

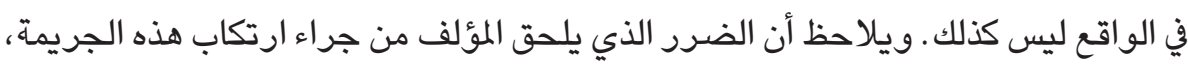

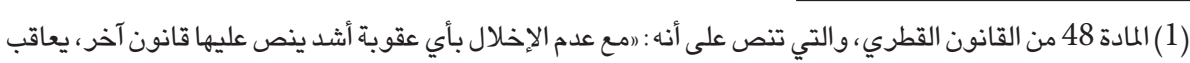

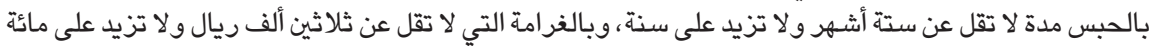

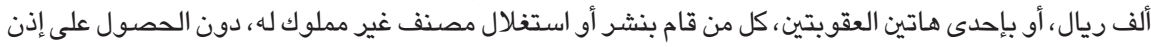

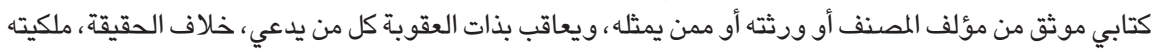

لمصنف غير مملوك لهاه ).

(2) (2) (المادة 48 من القانون القطري. (3) (3) (المادة 48 من القانون القطري. 
يصيب حقوق المؤلف المعنويةً والمالية على حد سواء، لأن المعتدي يظهر نفسه مظهر المالك للمصنف، وينسبه لنفسه زوراً، ويسعى لقطف المالية على ثماره المعنوية والمالية في آن.

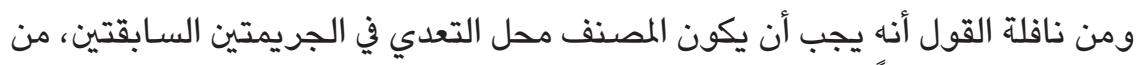

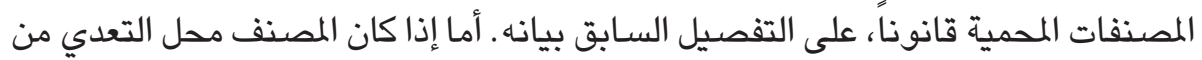

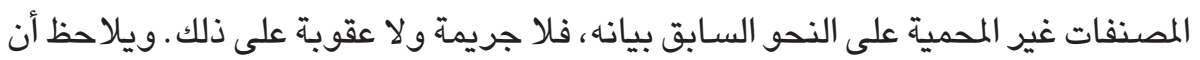

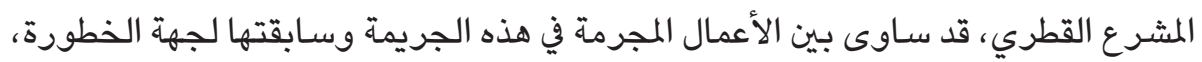

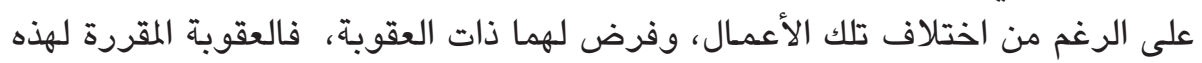

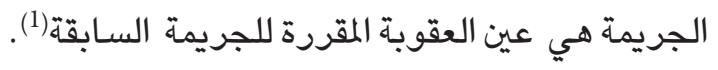

$$
\text { 3- جريمة تحريف المصنف: }
$$

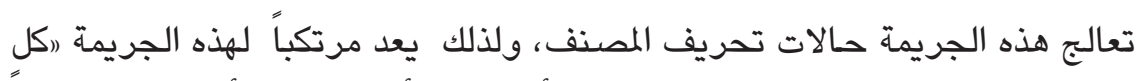

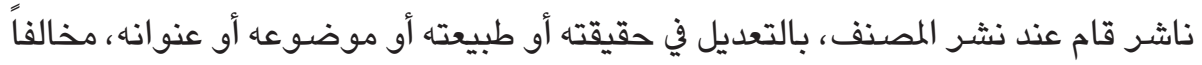

$$
\text { بذلك تعليمات مؤلف المصنف ورغبتهاه(2(2). }
$$

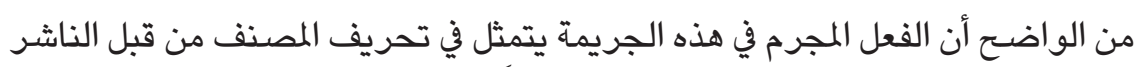

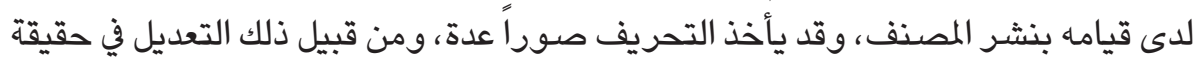

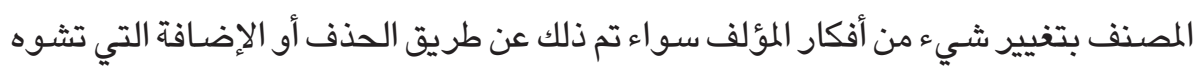

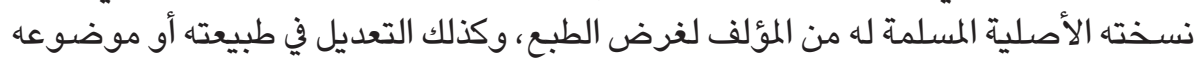

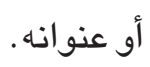

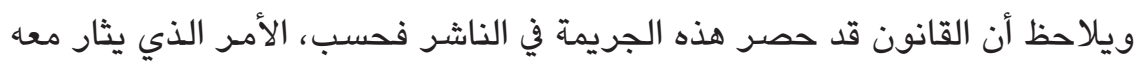

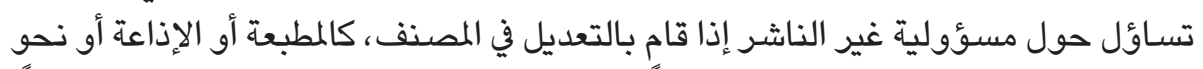

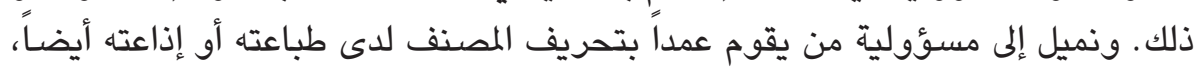

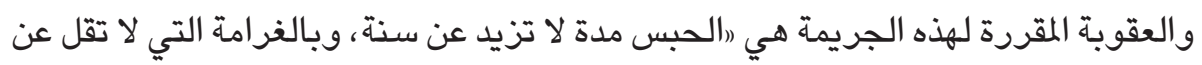

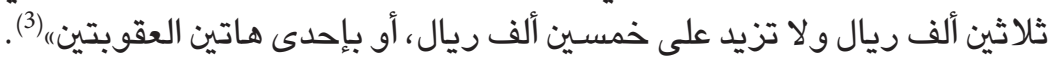

$$
\text { 4- جريمة توزيع المصنف: تولين }
$$

تعالج هذه الجريمة حالات توزيع المصنف بصورة غير مشروعة، ولذلك يعد مرتكباً

$$
\text { (1) (1) (المادة } 48 \text { من القانون القطري. }
$$

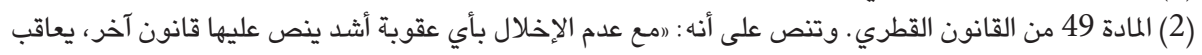

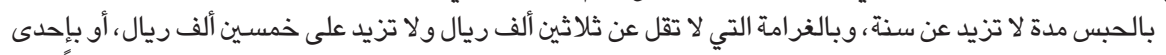

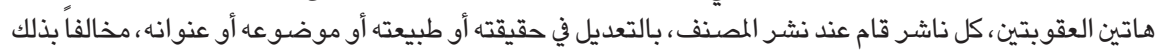

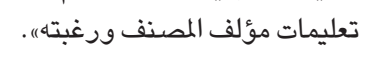

(3) (3) (المادة 49 من القانون القطري. 


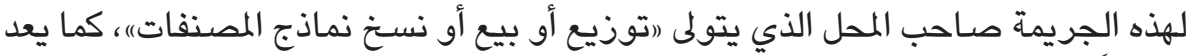

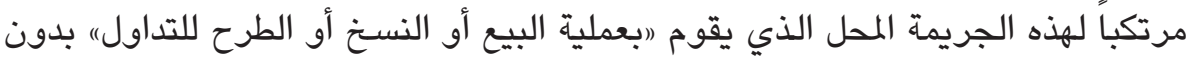
موافقة كتابية من المؤلف مالك المصنف، أو ممن يمثله الهئ.

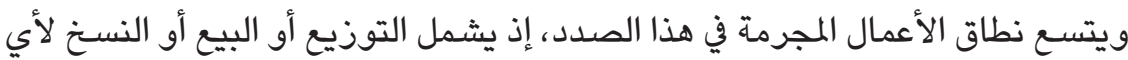

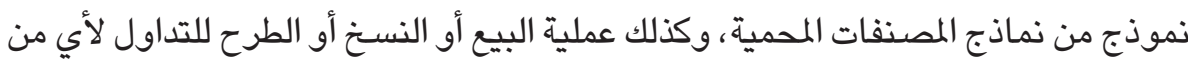

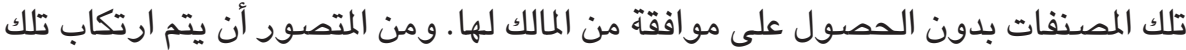

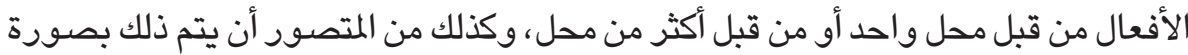
مستقلة أو مشتركة.

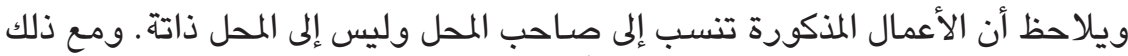

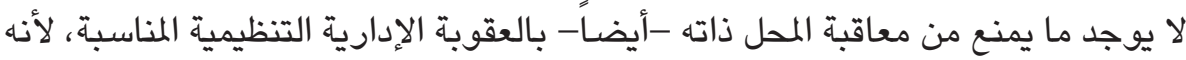

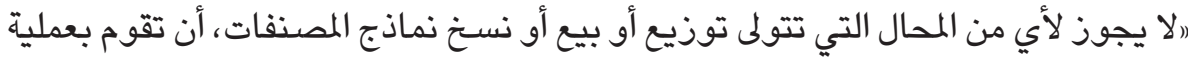

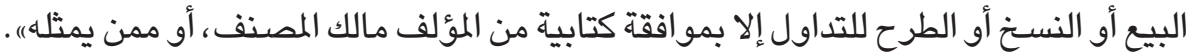

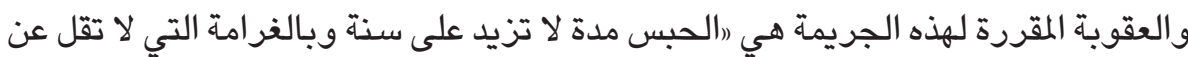

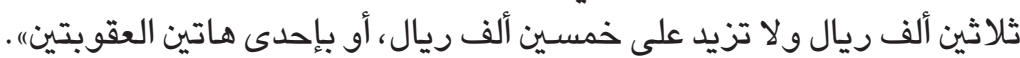

\section{5- جريمة الاستعمال غير المشروع للوسائل التقنية لغرض انتهاك المصنف:}

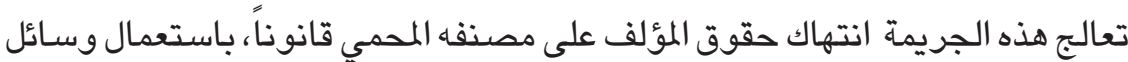

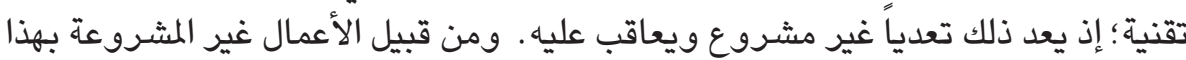

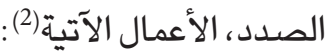

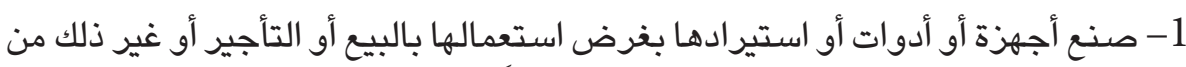

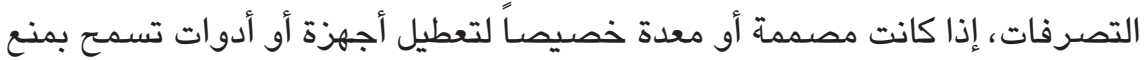

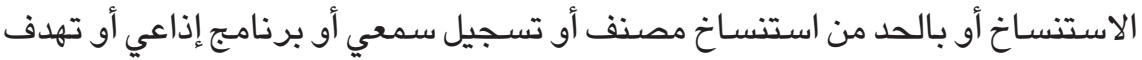

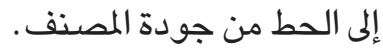

2- صنع أجهزة أو أدوات أو استيرادها بغرض استغلالها بالبيع أو التأجير أو غير ذلك من

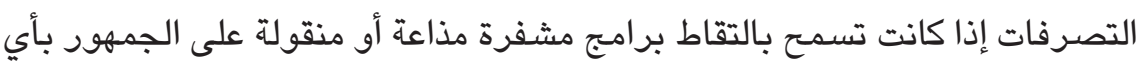

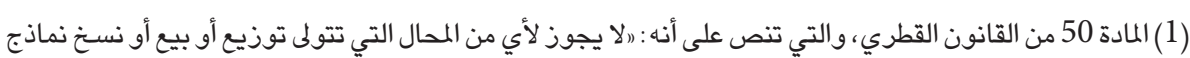

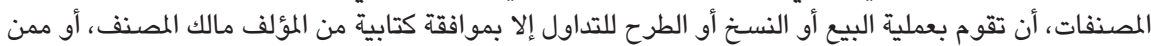

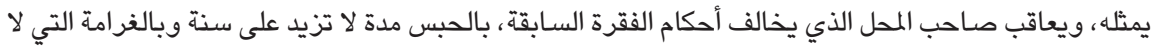

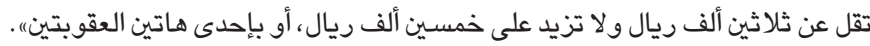

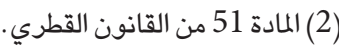


طريقة أخرى بما فيها البرامج المنقولة عبر الساتل (القمر الصناعي) أو تسمح بتسهيل

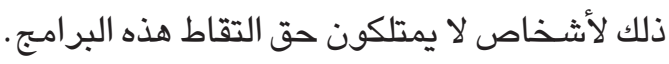

3- إزالة أي معلومات إلكترونية تتعلق بإدارة الحقوق أو تغييرها من دون تصريح.

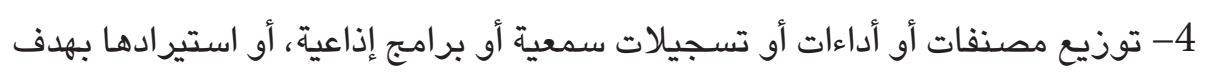

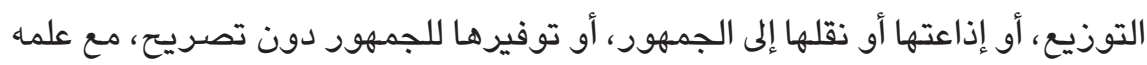

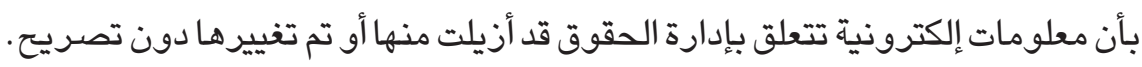

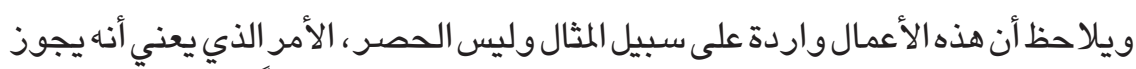

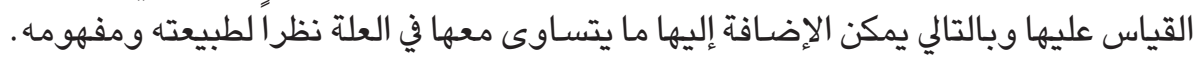

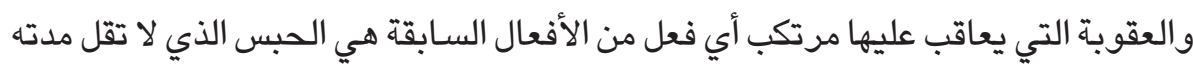

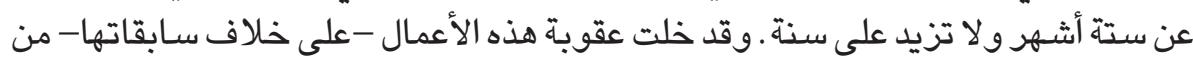

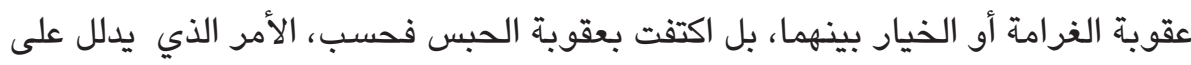

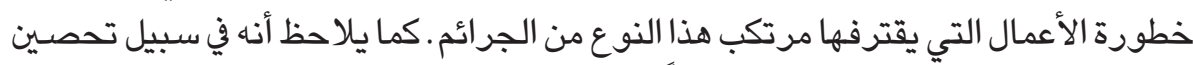

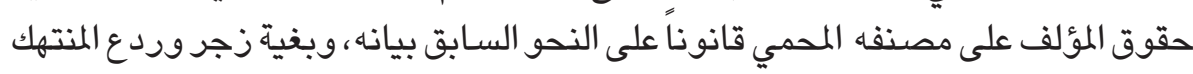

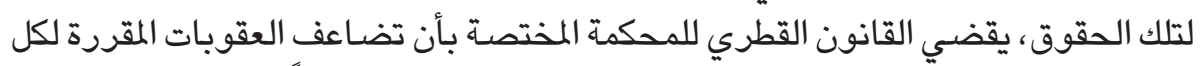

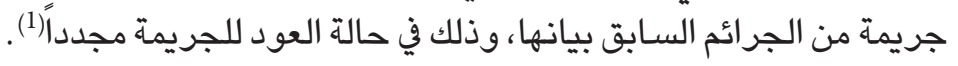

\section{العقوبات الإضـافية (التبعية):}

لم يكتف القانون القطري بالعقوبات المقررة، لكل من يرتكب أي جريمة من الجرائم

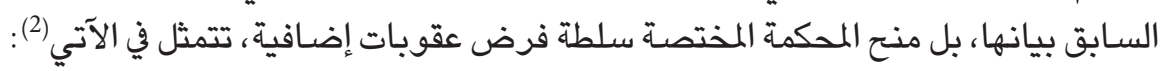

$$
\text { 1- المصادرة: - 1 }
$$

يتعين على المحكمة المختصة الناظرة لأي جريمة من الجرائم التي تعد انتهاكاً لحقوق

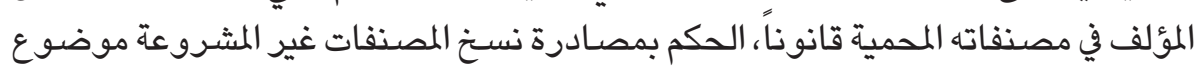

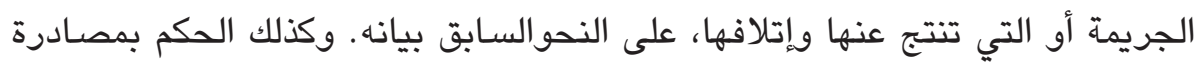

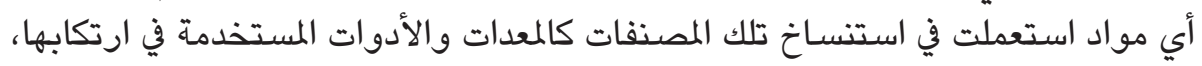

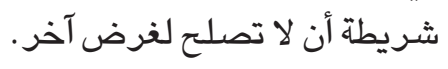

$$
\text { (1) (1) (المادة } 52 \text { من القانون القطري. }
$$

(2) المادة 52 من القانون القطري، والتي تنص على أنه في جميع الأحوال المبينة في هذا الباب، يتعين الحكم بمصادرة

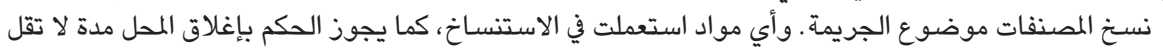

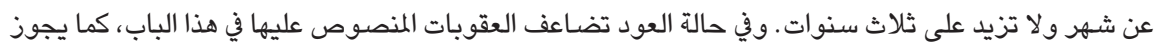
للمحكمة أن تأمر بنشر الحكم في جريدة أو أكثر على نفقة المحكوم عليه. 
ويلاحظ أن القانون القطري قد استعمل لدى النص على هذه العقوبة عبارة "يتعين

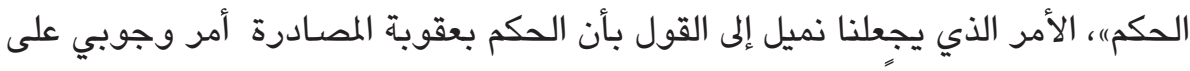

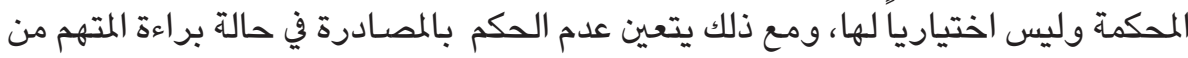

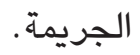

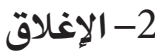

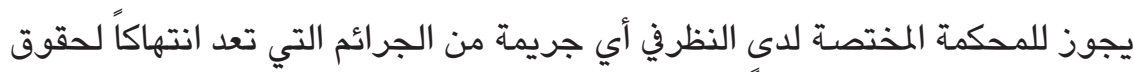

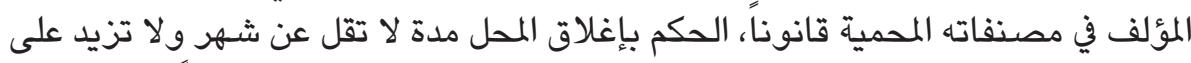

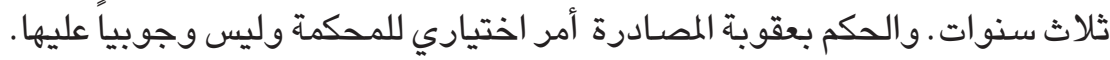

3- النشر:

يجوز للمحكمة المختصة لدى النظر في أي جريمة من الجرائم التي تعد انتهاكاً

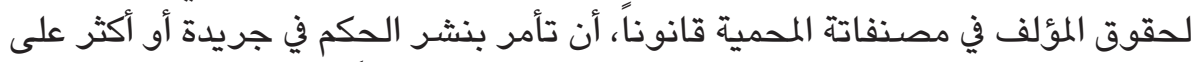

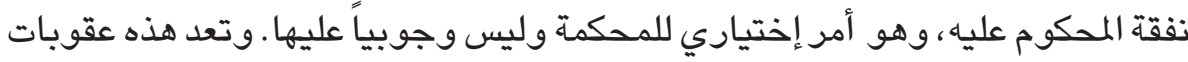

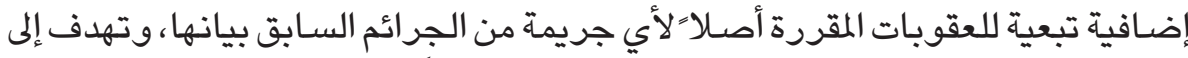

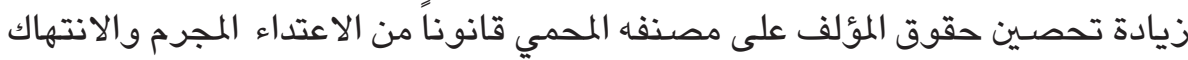

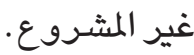

\section{الفرع الخامس}

\section{الحماية الدولية}

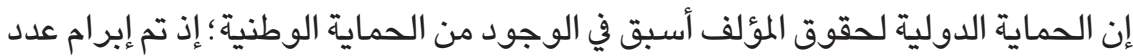

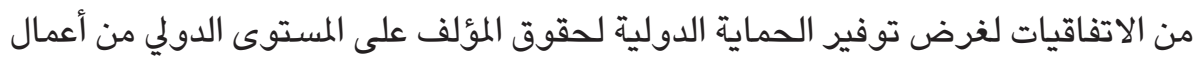
الانتهاك أو حالات القرصنة (1). ومن أبرز هذه الاتفاتية الاتيات، الآتي : أولاًا - اتفاقية برن لحماية المصنفات الأدبية والفنية لعام 1886: تعد اتفاقية برن أول اتفاقية لتنظيم حقوق المؤلف، والحقوق المجاورة على المستوى

(1) ومن الجدير بالذكر أن تعبير القرصنة يطلق على الجرائم التي تقع ضد السفن في عرض البحر أو ضد الطائرات في

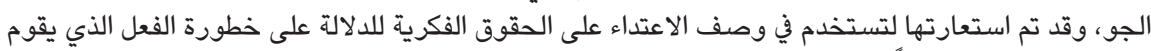

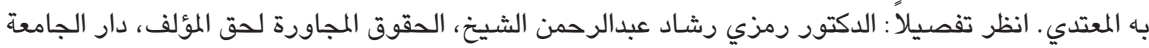

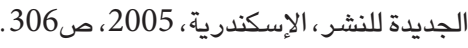




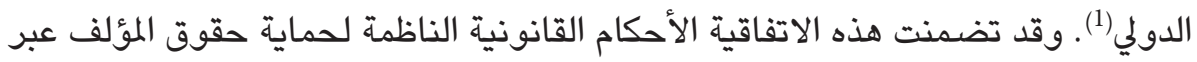

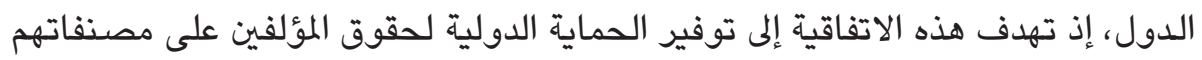

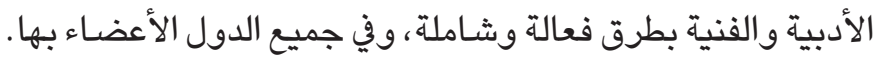

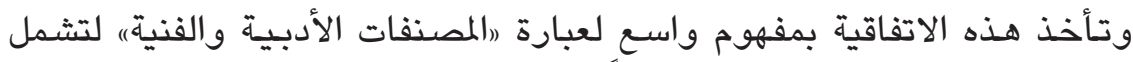

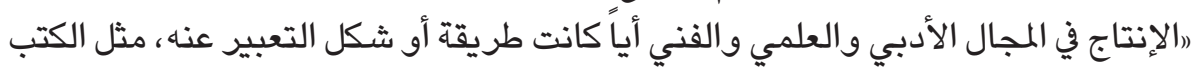

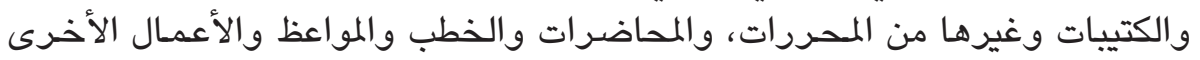

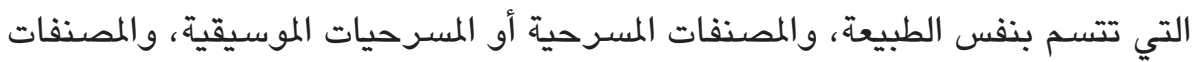

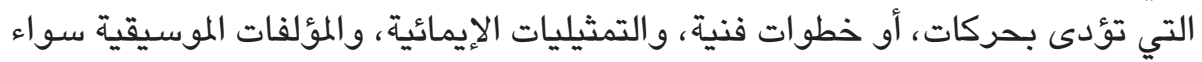

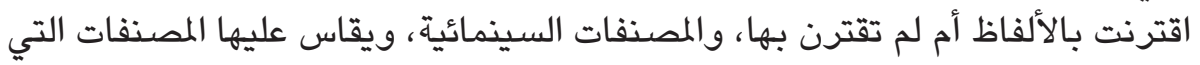

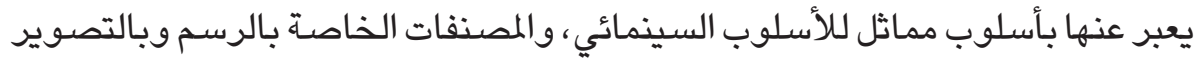

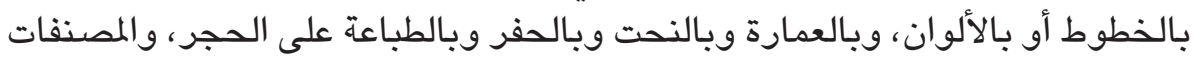

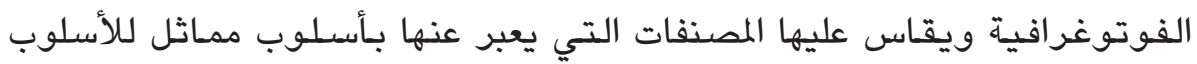

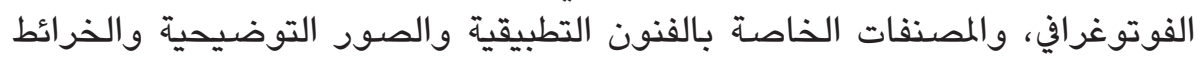

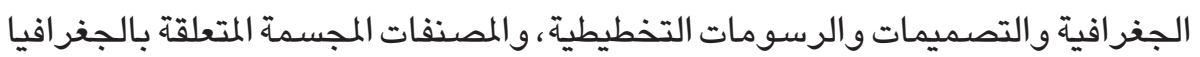

$$
\text { أو الطبوغرافيا أو العمارة أو العلوم)|(2). }
$$

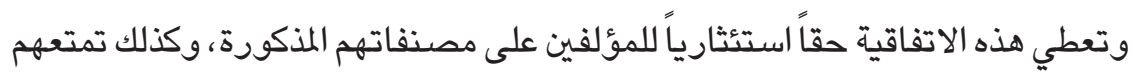

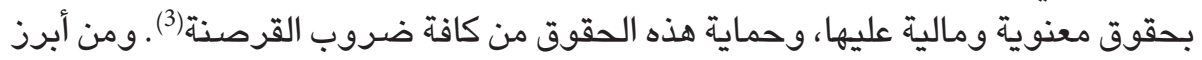
المبادئ الرئيسة لهذه الاتفاقية ما يلي (4): أ) مبدأ المعاملة الوطنية: يعني هذا المبدأ، أن تتمتع المصنفات في دول الاتحاد بالحماية

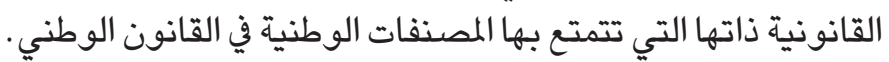

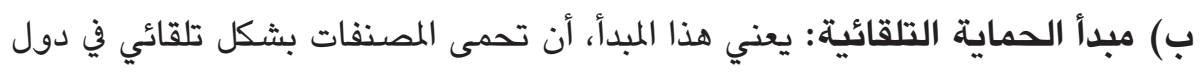

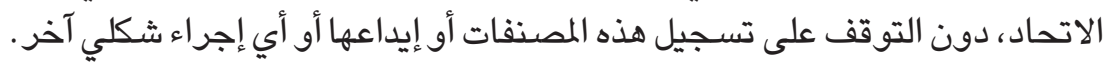
ج) مبدأ استقلالية الحماية: يعني هذا المبدأ، أن تتمتع المصنفات بالحماية القانونية في دول الاتحاد حتى لو لم تكن قابل للحماية في دولتها، أي دولة المبلة المنشأ.

(1) وقد خضعت هذه الاتفاقية للتعديلات، وكان أبرزها التعديل الذي جرى في بروكسل عام 1948، واستوكهولم عام

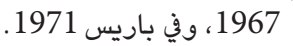
(2) المادة 2 من اتفاقية برن لحماية المصنفات الأدبية والفنية لعام 1967 ون 1886. (3) (3) المادة 9 من اتفاقية برن.

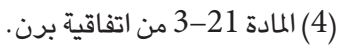


ثانياً - اتفاق الجوانب المتصلة بالتجارة من حقوق الملكية الفكرية (تربس TRIPS)

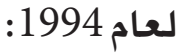

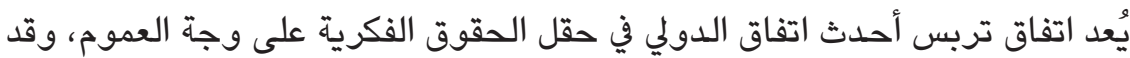

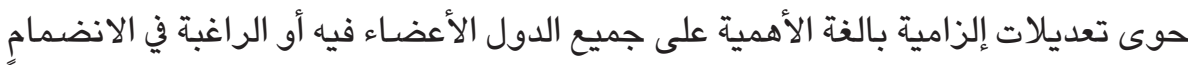

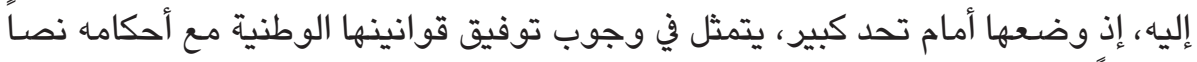
وروحاً.

ونكتفي في هذا المقام بالإثـارة إلى أهم ما جاء به هذا الاتفاق في شأن حماية حقوق المؤلف(1):

1- مراعاة الأحكام التي تنص عليها المـواد من 1 وحتى 21 من معاهدة برن (1971)

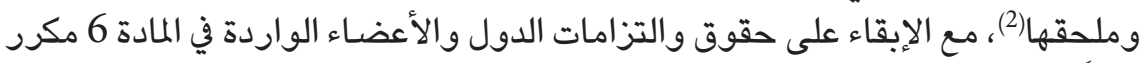

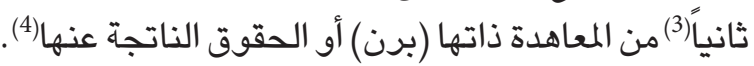

$$
\text { 2- اعتبار برامج الحاسب مصنفات أدبية. }
$$

3- اعتبار تجميع البيانات، أو أية مواد أخرى في حد ذاته مصنفاً محمياً. 4- حماية حقوق تأجير المصنف. 5- حماية الحقوق المالية للمصنف لمدة طويلة لا تقل عن 50 سنة بعد وفاته.

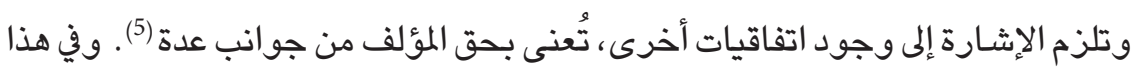

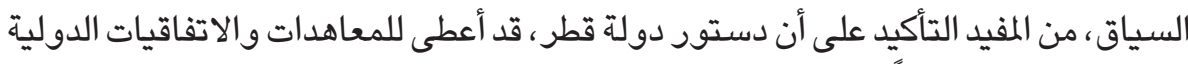

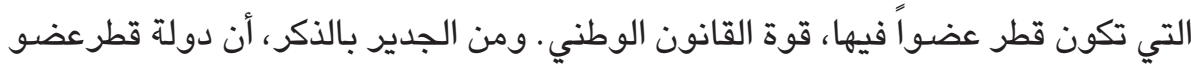

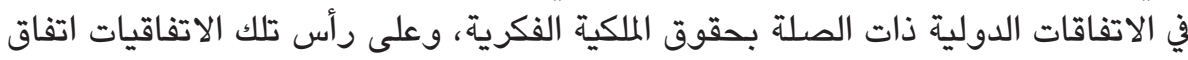

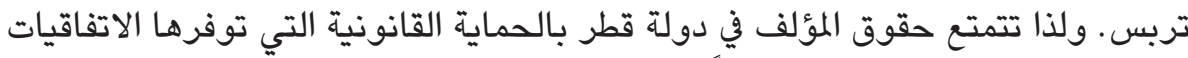

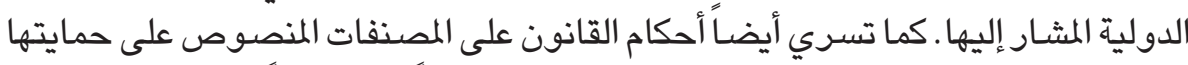

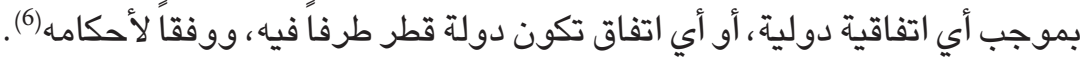

(1) المادة 9 و10 و12 من اتفاقية تربس.

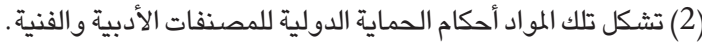
(3) وتنظم هذه المادة الحقوق المعنوية للمؤلف.

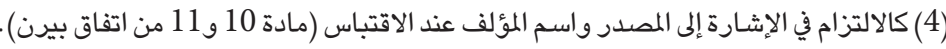

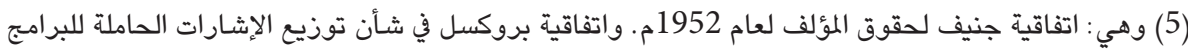

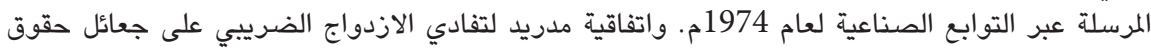




\section{المقبث الثاني \\ الحقوق المجاورة}

ترتبط الحقوق المجاورة بحقوق المؤلف، كونها تستند في وجودها على هذه الأخيرة.

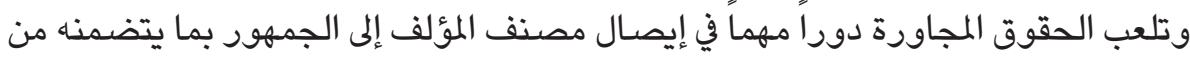

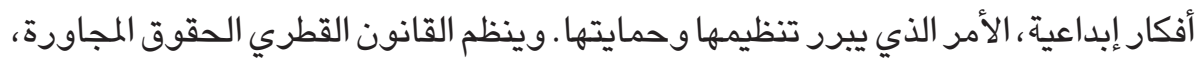

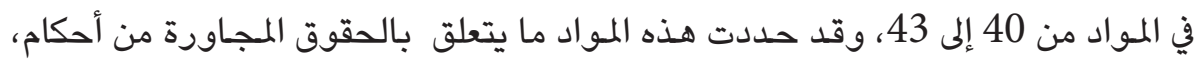

ونستعرض ذلك في مطالب على التوالي.

المطلب الأول: التعريف بالحقوق المجاورة

المطلب الثاني: حقوق أصحاب الحقوق المجاورة المطلب الثالث: الحماية القانونية لأصحاب الحقوق المجابوقاورة المجاوة

\section{الملطلب الأول \\ التعريف بالحقوق المجاورة}

نبين في هذا المبحث نشأة الحقوق المجاورة وتعريفها وتحديد أصحابها، وذلك في الفروع التالية:

\section{الفرع الأول}

\section{نشأة الحقوق المجاورة}

نشأت الحقوق المجاورة في ظل حقوق المؤلف، لكونها تستتد في وجودها إلى المصنفات

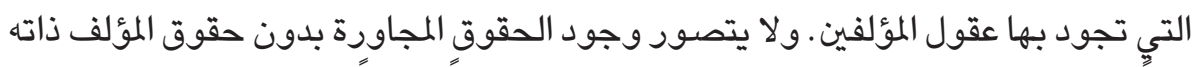

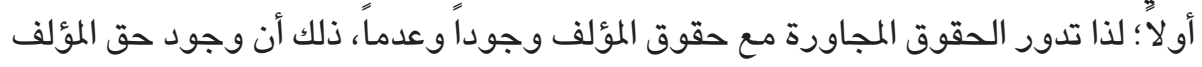

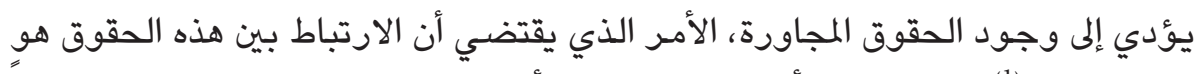

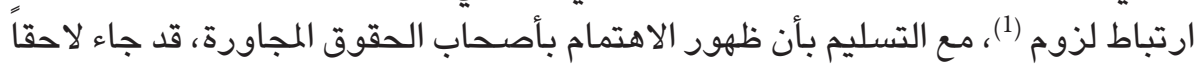


للاهتمام بحقوق المؤلفين، على سند من القول، بأن الأولين يقومون بأعمال تسهـم بقوة في

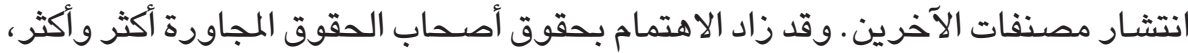

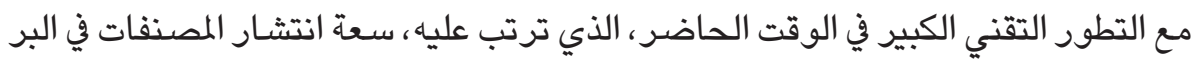
والبحر والجو على السواء.

\section{الفرع الثاني}

\section{تعريف الحقوق المجاورة}

يقصد بالحقوق المجاورة: الحقوق التي يمنحها القانون لأشخاص معينين، لقيامهم

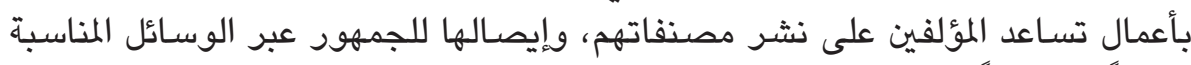

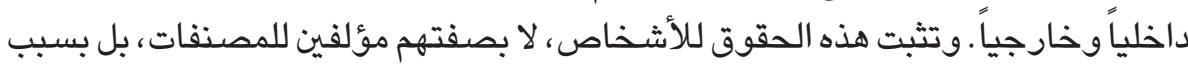

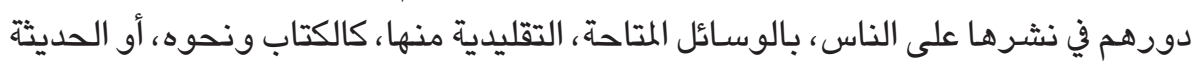
منها، كالشريط ونحوه، لتصل الناس في مواقعهم في أرجاء المعمورة (1).

\section{الفرع الثالث}

\section{تحديد أصحاب الحقوق المجاورة}

أصحاب الحقوق المجاورة في القانون القطري، هم: فنانو الأداء ومنتجو التسجيلات السمعية وهيئات الإذاعة(2) : ألمات

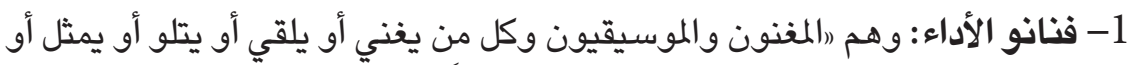

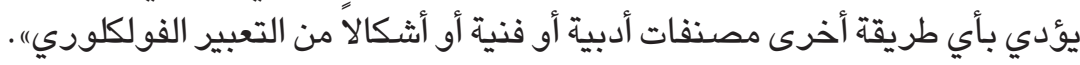
وعليه، يعد من أصحاب الحقوق المجاورة، المغني والموسيقي والملقي والراقص والممثل

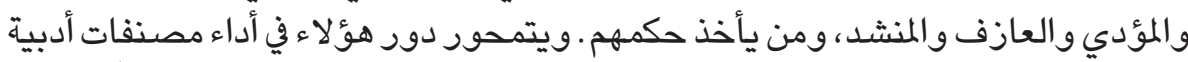

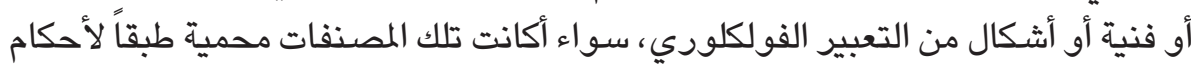

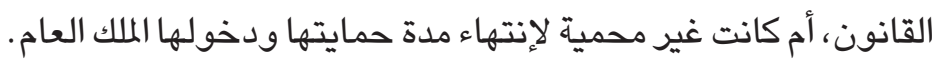

$$
\begin{aligned}
& \text { (1) الدكتور محمد حسام محمود لطفي، المرجع السابق، ص20. } \\
& \text { (2) (1) مادة } 1 \text { من القانون القطري. }
\end{aligned}
$$




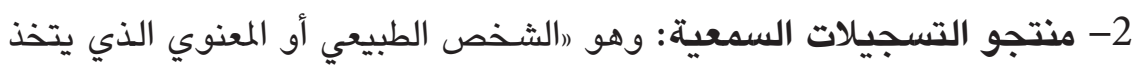

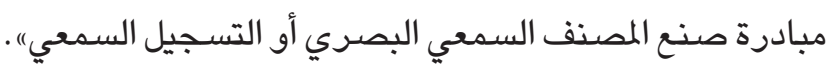

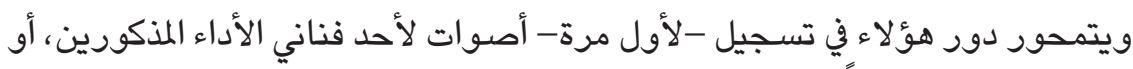

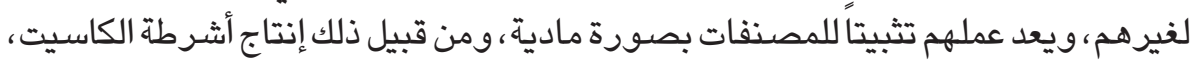
أو الأسطوانات أو نحو ذلك.

3- هيئات الإذاعةة وهي التي تقوم بعملية (رنقل المصنف أو الأداء أو التسجيل الصوتي

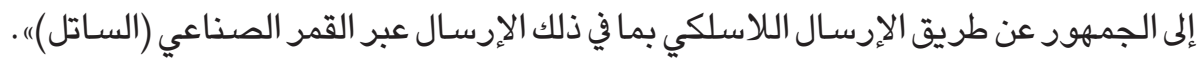

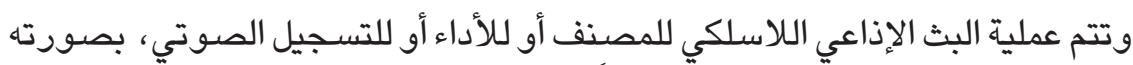

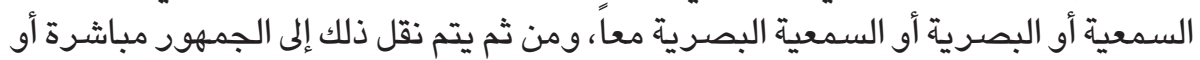
مسجلاً، وبطريقة لاسلكية عبر التوابع أو الأقمار الصناعية.

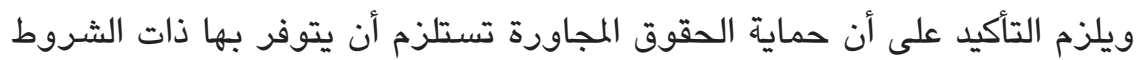

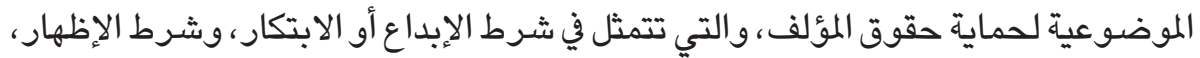

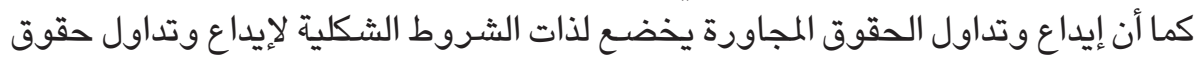

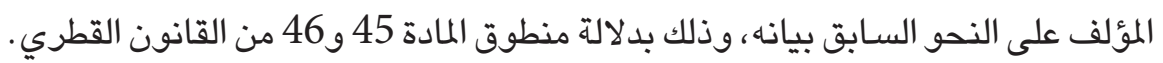

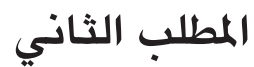

\section{حقوق أصحاب الحقوق المجاورة والقيود الواردة عليها}

يعطي القانون فناني الأداء ومنتجي التسجيلات السمعية وهيئات الإذاعة حقوقاً محددة

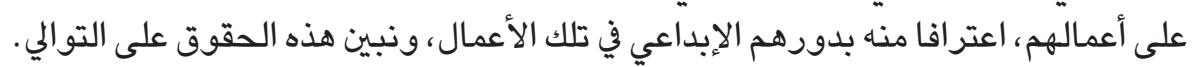

\section{الفرع الأول}

\section{حقوق أصحاب الحقوق المجاورة}

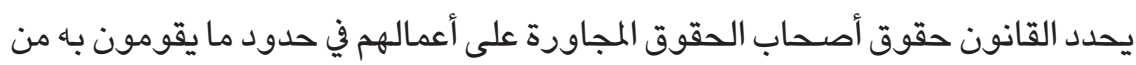

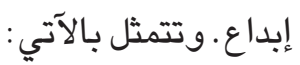


أولاًا - حقوق فناني الأداء:

يتمتع فنانو الأداء بحقوق أدبية وأخرى مالية على أعمالهم. ونبين بإيجاز هذه الحقوق تباعاً (1):

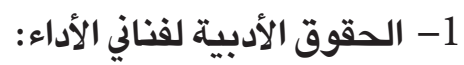

يتمتع فنانو الأداء بالحقوق الأدبية التالية :

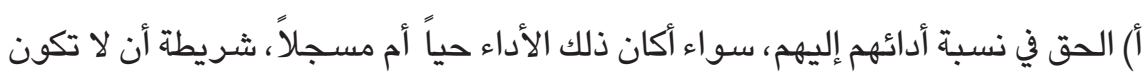
طريقة الانتفاع بالأداء تتعارض مع ذكر أستوائه أسمائهم أو صفاتهم.

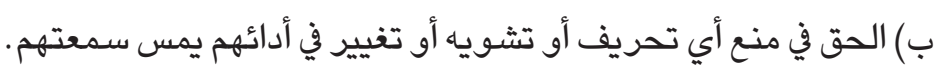

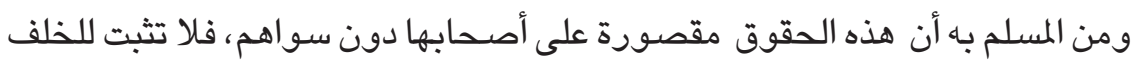

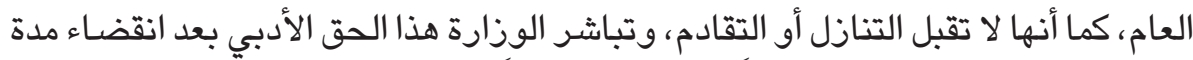

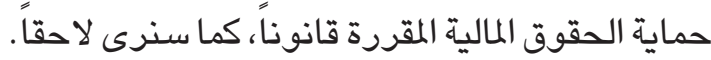

2- الحقوق المالية لفناني الأداء:

يتمتع فنانو الأداء بالحقوق المالية الآتية:

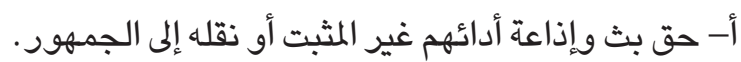
ب- حق التثبيت أو التسجيل لأدائهم السمعي الذي لم يثبت بعد. ت - حق نسخ التسجيلات السمعية التي تتضمن تثبيتاً غير مجاز لأدائهم. ث- حق التأجير التجاري للتسجيلات السمعية المتضمنة أدائهم. ج- حق التوزيع للجمهور من خلال البيع للتسجيلات السمعية المتضمنة أدائهم. ويتمتع فنانو الأداء، في سبيل استغلال أدائهم، بحق إبرام عقود بالشروط القانونية التي

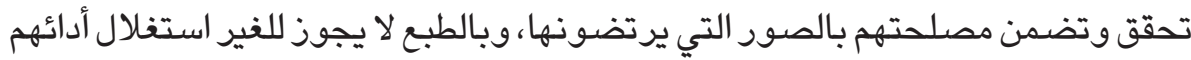
بلدون حصوله على موافقتهم على ذلك.

ومدة حماية الحقوق المالية المذكورة خمسون عاماً، تبدأ اعتباراً من السنة التالية

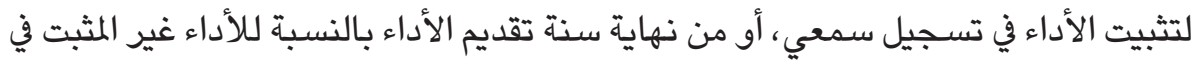

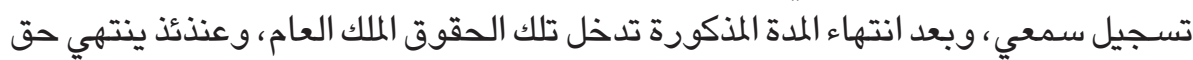

الاستئثار بها.

(1) (1) (المادة 40 من القانون القطري. 


\section{ثانياً - حقوق منتجي التسجيلات السمعية:}

يتمتع منتج التسجيل السمعي، وحده دون غيره ، بالحق في مباشرة الأعمال التالية(1): 1- الاستنساخ المباشر أو غير المباشر للتسجيل السمعي بأي طريقة وفي أي شكل آخر .

$$
\text { 3- أتوزير نسخة عن التسجيل السمعي للجمهور . للجمهور من خلال البيع. }
$$

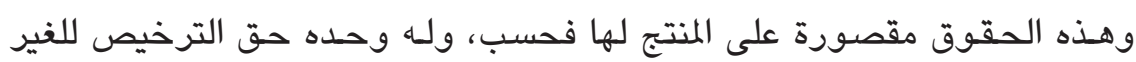

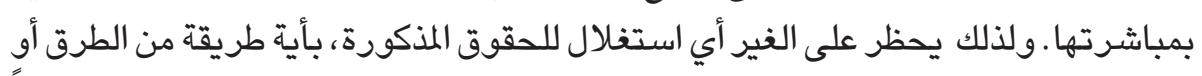

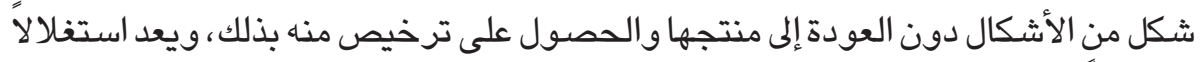

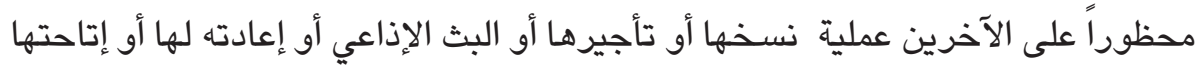
بوسائل سلكية أو لاسلكية أو عبر أجهزة الحاسب أو غير غيرها من الوسائل.

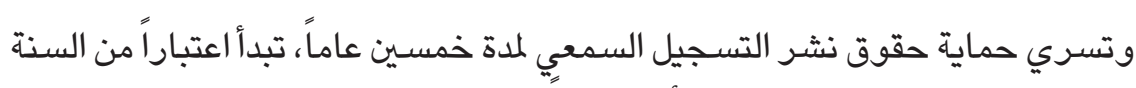

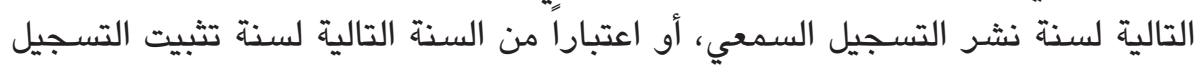

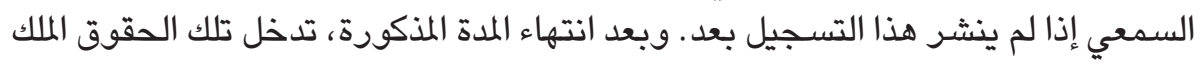

العام، وعنذئذ ينتهى حق الاستئثار بها.

$$
\text { ثالثاً - حقوق هيئات الإذاعة: }
$$

تتمتع هيئات الإذاعة، وحدها دون غيرها، بالحق في مباشرة الأعمال التالية(2):

$$
\text { 3- 1- 1- إعادة بث برامجها الإذاعية. }
$$

وهذه الحقوق مقصورة على هيئة الإذاعة فحسب، ولها وحدها حق الترخيص للغير التهائ

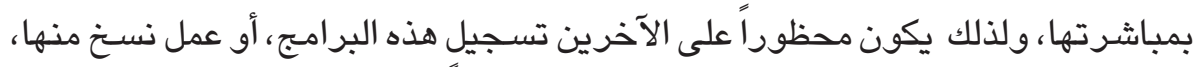

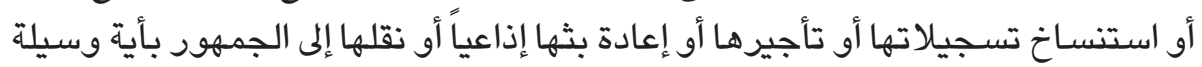


وتمتد حماية حقوق نشر التسجيل السمعي لمدة عشرين سنة، تبدأ من السنة التالية

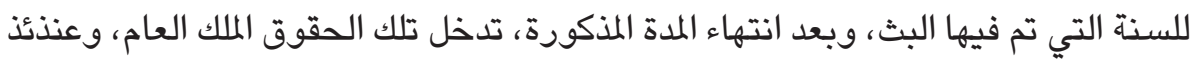

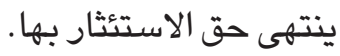

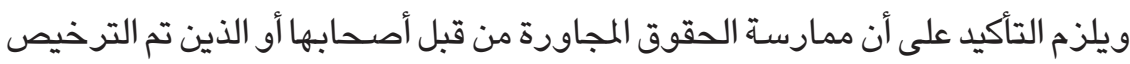

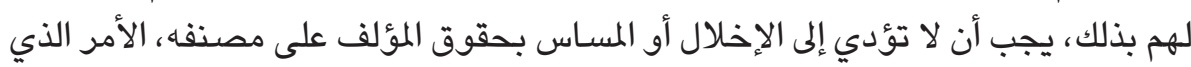

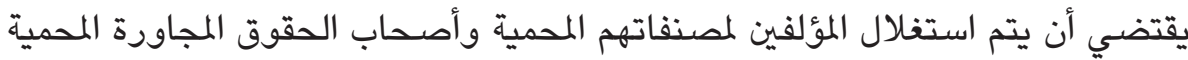

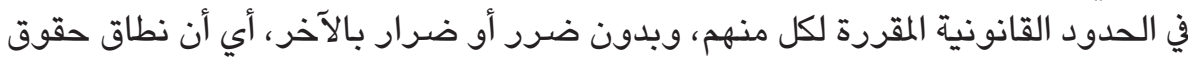

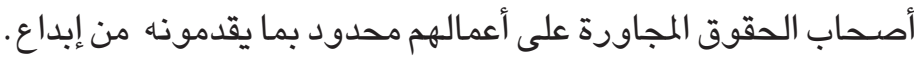

\section{الفرع الثاني}

\section{القيود الواردة على الحقوق المالية \\ لأصحاب الحقوق المجاورة}

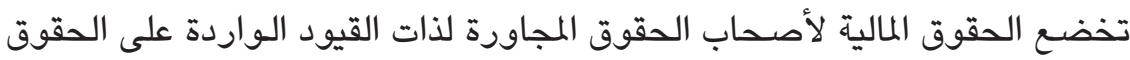

المالية للمؤلف على مصنفه، وذلك بدلالة منطوق المادة 26 من القانون القطري الماتئ.

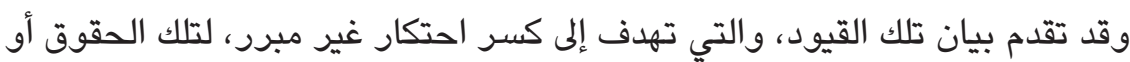

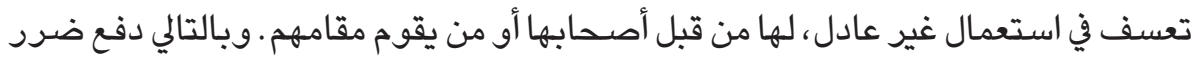

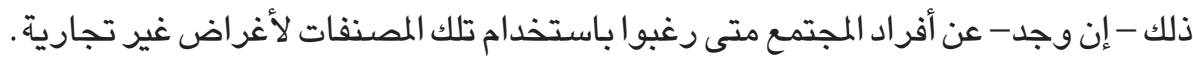

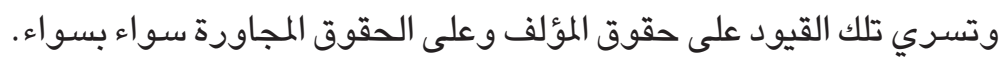

\section{المطلب الثالث}

\section{الحماية القانونية لأصحاب الحقوق المجاورة}

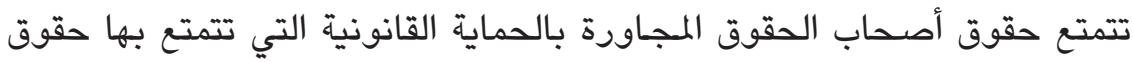

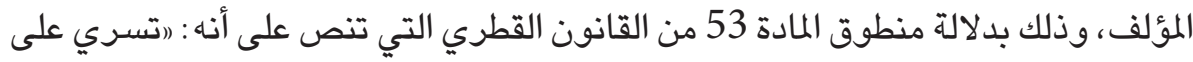

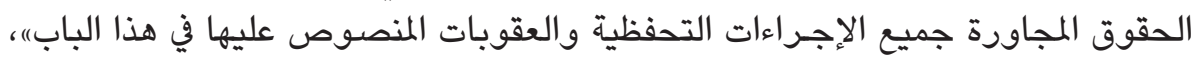
(1) والتي تنص على أنه : اتنطبق القيود الواردة بشأن الحقوق المالية في هذا الباب على حقوق فناني الأداء ومنتجي التسهيلات السمعية وهيئات الإذاعة، وذلك بما يتناسب وطبيعة تلك الحقوق،. 
الأمـر الذي يمكن معه القول بأن حماية حقوق أصحاب الحقوق المجاورة، تحظى بنفس

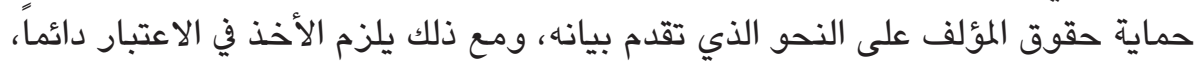

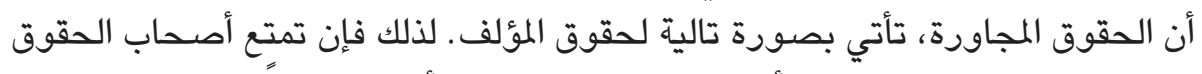

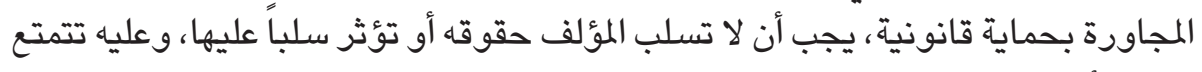

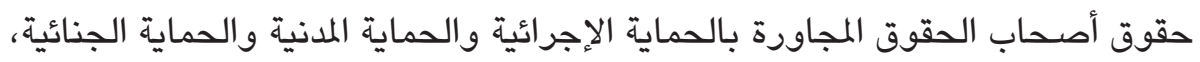

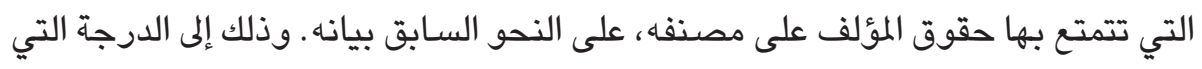

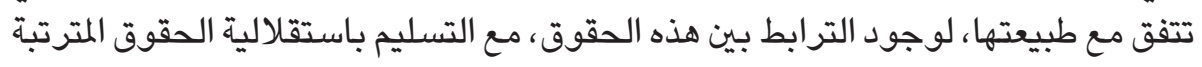

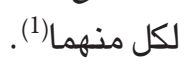
وتستظل بأحكام القانون القطري الحقوق المجاورة الآتية(2): 1- أداءات فناني الأداء القطريين.

2- التسجيلات السمعية للمنتجين القطريين أو التسجيلات التي تم تسجيلها أو نشرها في قطر.

3- برامج هيئات الإذاعة إذا كان المركز الرئيسي لهذه الهيئات في قطر، أو إذا تم بث برامجها

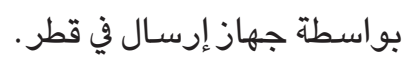

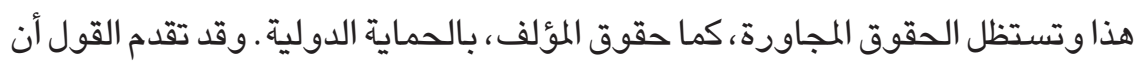

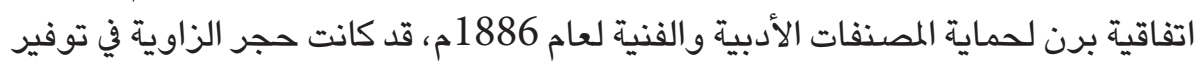

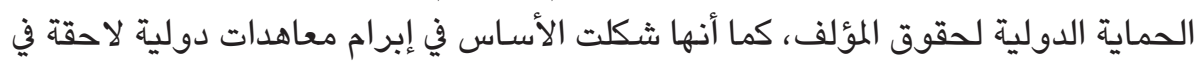

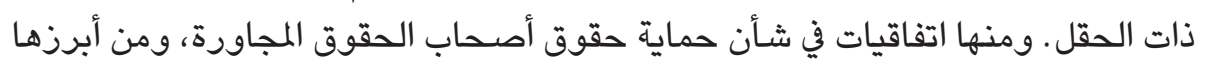
ما يلي (3)

(1) الدكتور رمزي رشاد الشيخ، الحقوق المجاورة لحق المؤلف، دار الجامعة الجديدة للنشر، الإسكندرية، سنة2005،

(3) WIPO/IP/BAH/05/2 -MARCH- 2005

(2) (2) (المادة 43 من القانون القطري 


\section{الفرع الأول \\ اتفاقية روما في شأن حماية فناني الأداء}

ومنتجي التسجيلات الصوتية وهيئات الإذاعة لعام 1961

تم توقيع اتفاقية روما بتاريخ 26 تشرين الأول لعام 1961، وتعرف بـ بـ (اتفاقية حماية

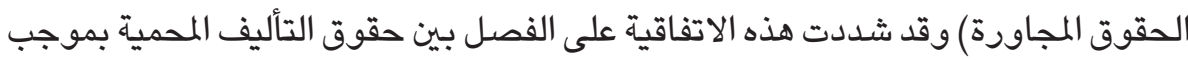

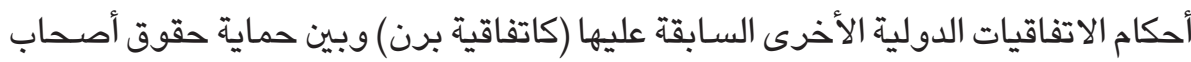

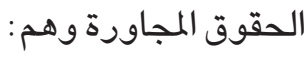

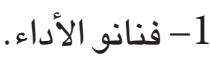

$$
\text { 2- 3- هنتجو التسجيالات الصوتية. }
$$

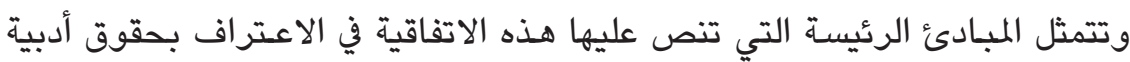

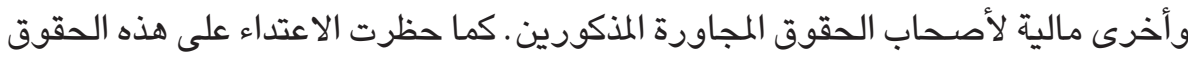

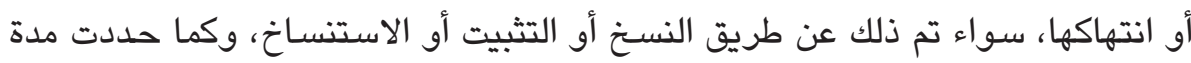

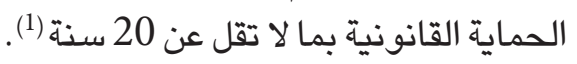

$$
\text { الفرع الثاني }
$$

$$
\text { اتفاقية جنيف في شأن حماية }
$$$$
\text { منتجي الفونوغرامات (التسجيلات) }
$$

\section{من استنساخ فونوغراماتهم دون تصريح لعام 1971}

تهدف هذه الاتفاقية إلى حماية التسجيلات الصوتية من القرصنة عبر الحدود، وقد

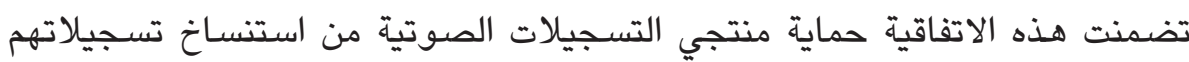

$$
\text { الصوتية بصورة غير مشروعة هذهة الاتفة حمنة }
$$

(2)WIPO/IP/BAH/05/2 -MARCH- 2005

$$
\text { (1) - (1) (المادة } 7 \text { و 13 من اتفاق روما. }
$$




\section{الفرع الثالث \\ اتفاقية بروكسل بشأن توزيع الإثـارات الحاملة \\ للبرامج المرسلة عبر التوابع الصناعية لعام 1974}

تهدف هذه الاتفاقية إلى تنظيم وحماية توزيع الإشـارات الحاملة للبرامج المرسلة عبر

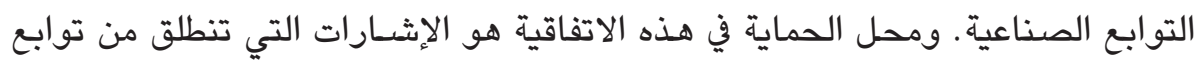

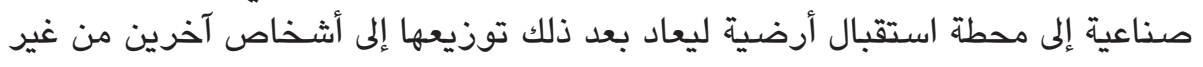
المستفيدين أو المعنيين بوصول تلك الإثـارات إليهم.

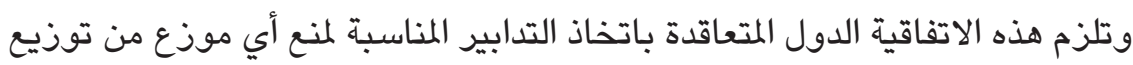

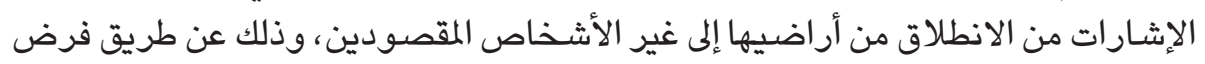

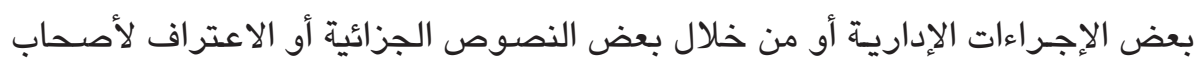

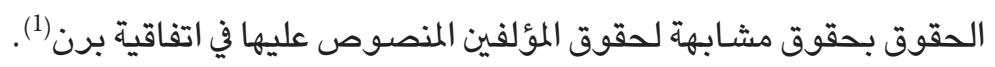

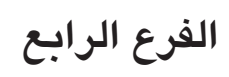

\section{اتفاق الجوانب المتصلة بالتجارة من حقوق الملكية الفكرية (تربس TRIPS) لعام 1994}

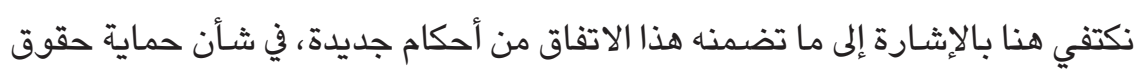

$$
\text { أصحاب الحقوق المجاورة وأبزرها الآتي (2): }
$$

1- حماية حق فناني الأداء ومنتجي الفونوجرامات في تعويض عادل نظير البث الإذاعي التجاري لفونوجراماتهم.

$$
\text { 2- منح حق التأجير لفناني الأداء في حدود التشريع الوطني. }
$$

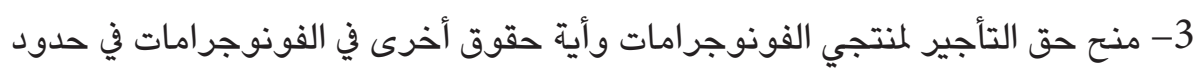
التشريع الوطني.

(1) WIPO/IP/BAH/05/2 -MARCH- 2005 
4- جعل مدة حماية فناني الأداء ومنتجي الفونوجرامات، دون هيئات الإذاعة، خمسين سنة محسوبة من نهاية السنة الميلادية التي تم فيها التثبيت أو الأداء أو البث.

وتسري أحكام القانون القطري على الأداءات أو التسجيلات السمعية أو البرامج

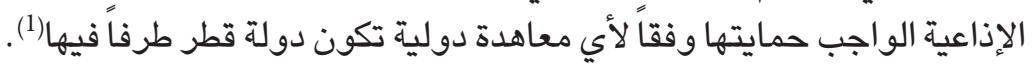

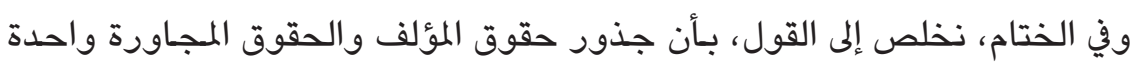

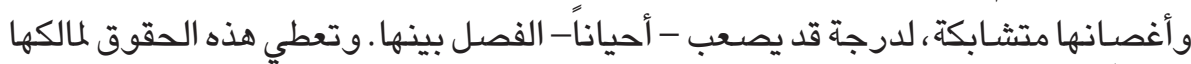

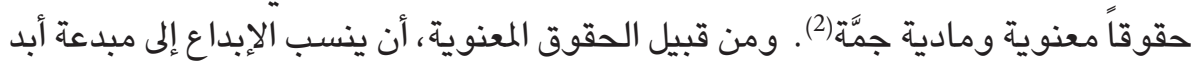

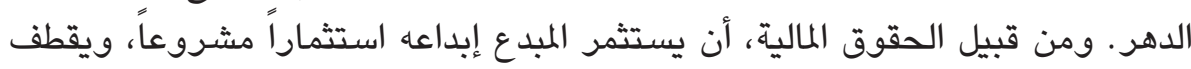

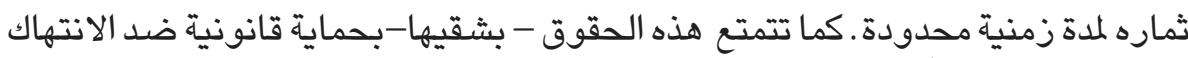

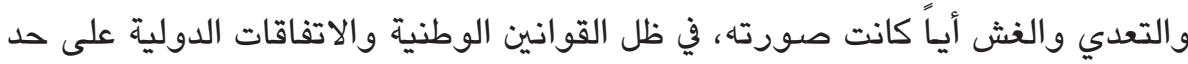

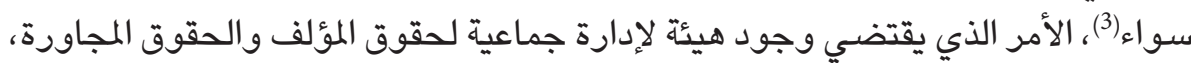
وذلك لأن هذه الحقوق متحدة في الطبيعة ومتداخلة في المضمون ومتعددة لاعدة في الملكية.

إن وجود هذه الإدارة أمر يُمكن معه استغلال تلك الحقوقٍ بصورة أفضل وممارستها

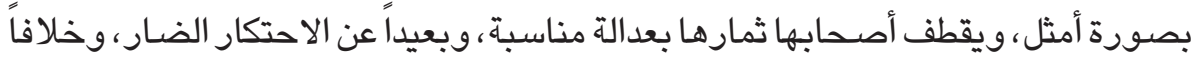
للمنافسـة غير الشريفة.

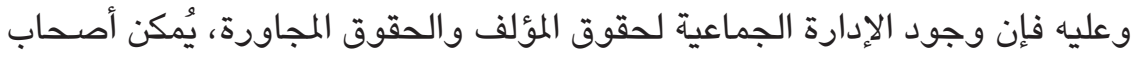

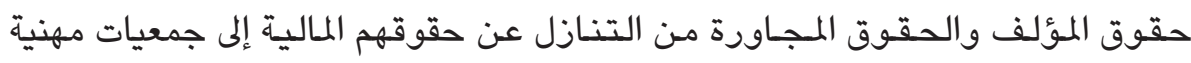

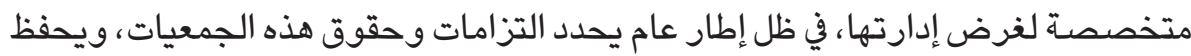

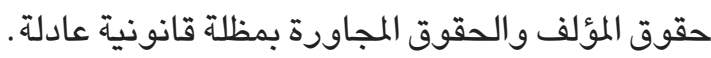

ومن قبيل الالتزامات الأسـاسية التي ينبغي أن تلتزم بها الإدارة الجماعية لحقوق

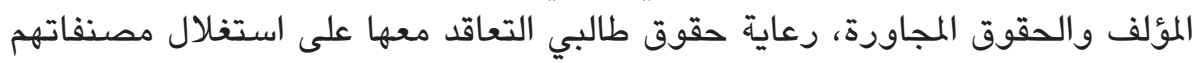

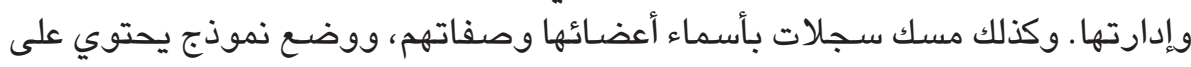

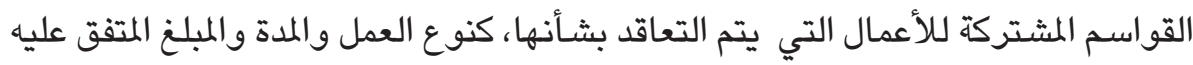
ونحو ذلك.

(1) مادة 43 من اتفاقية تربس.

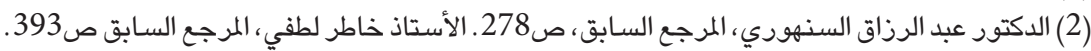

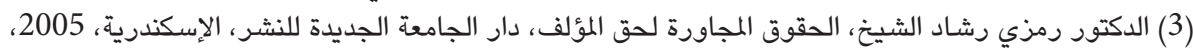

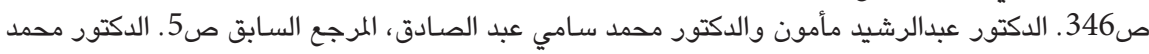

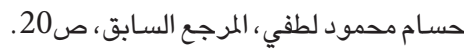




\section{الخاتمة (النتائج و التوصيات):}

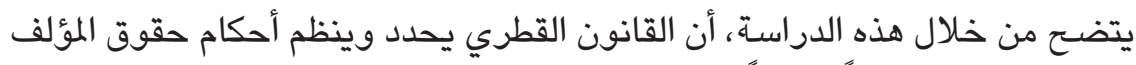

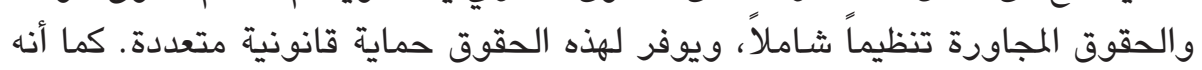

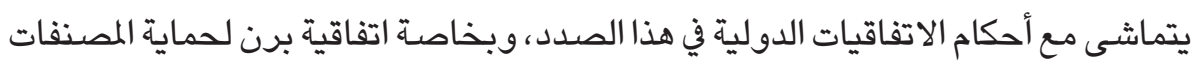

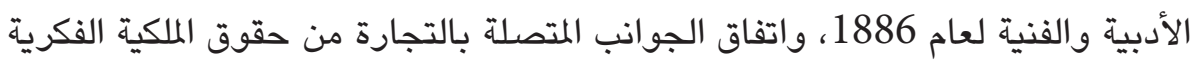

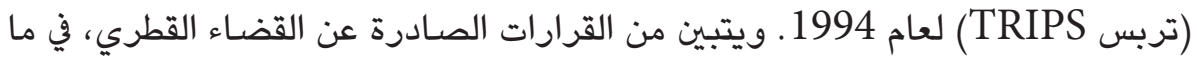

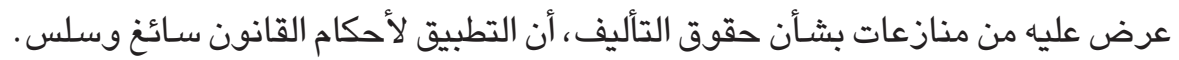

$$
\text { ومع ذلك نخلص إلى بعض الملاحظات والاقتراحات: }
$$

1. إن المادة 2 من القانون القطري، قصرت الحماية القانونية على المصنفات المبتكرة في

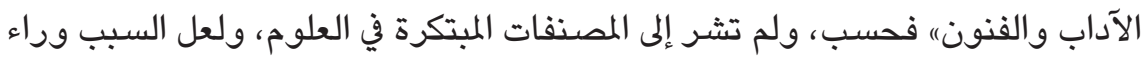

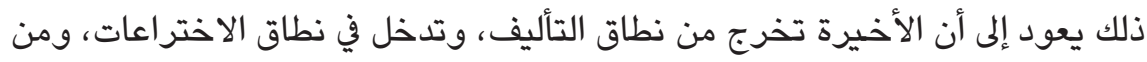

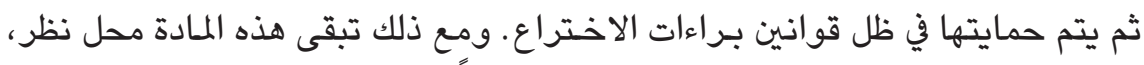

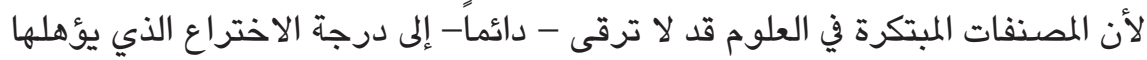

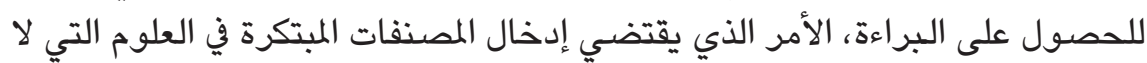

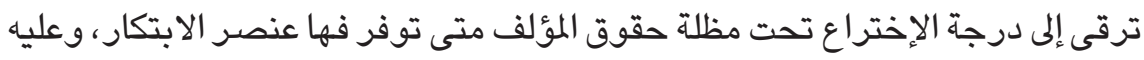
ينبغي تدارك هذا القصور .

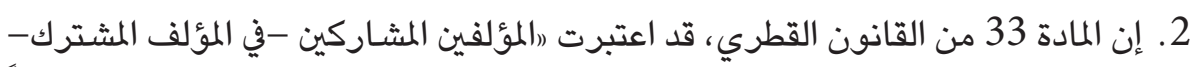

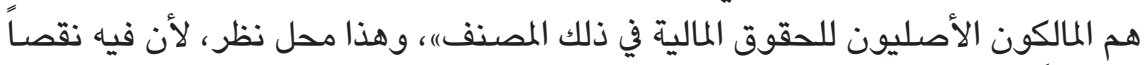

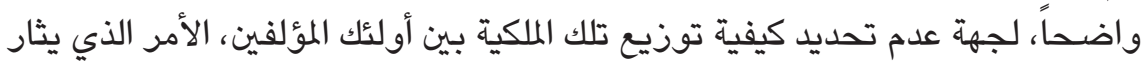

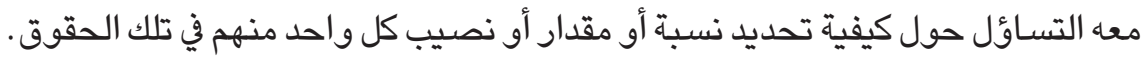

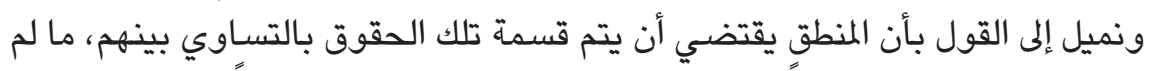

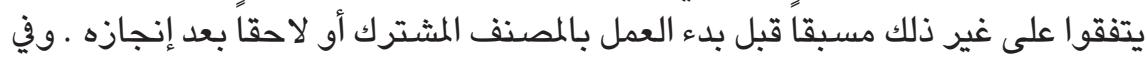

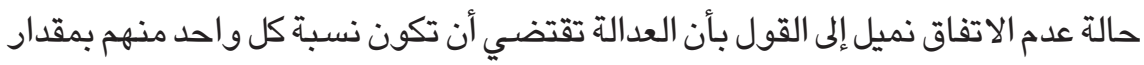

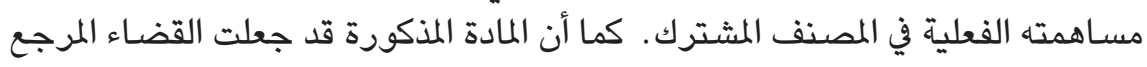

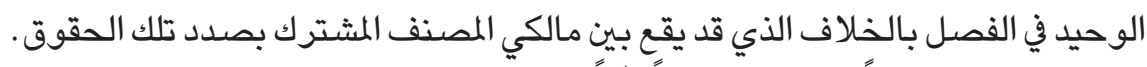

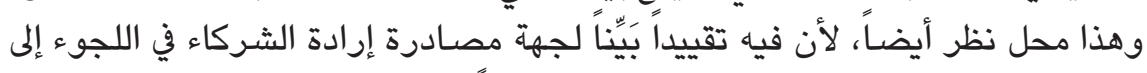

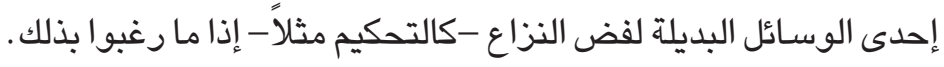

3. لقد خلا القانون القطري من نص يعالج حق المؤلف الذي سبق له التصرف باستغلال

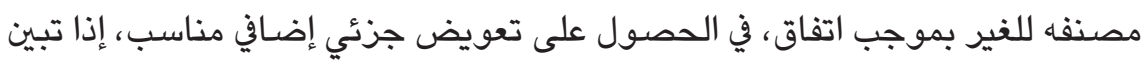


أن ذلك الاتفاق لم يكن عادلاً بحقه، أو أصبح كذلك لظروف وأسباب كانت خافية وقت

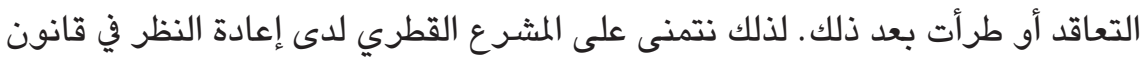

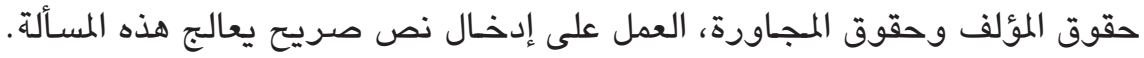

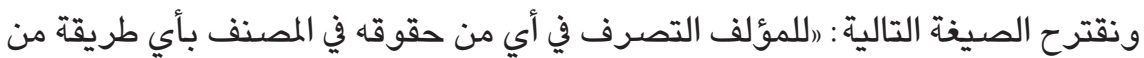

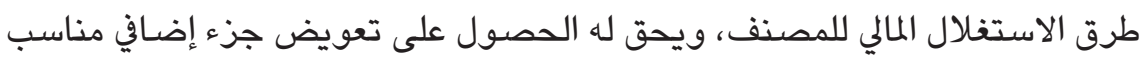

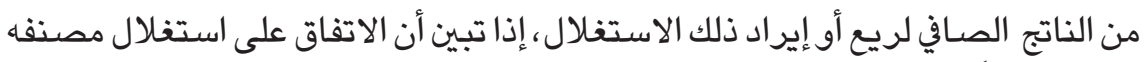

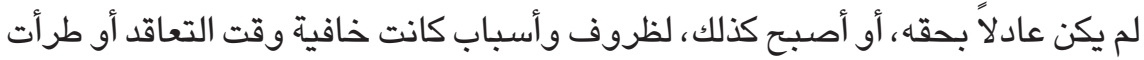

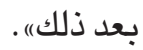

4. تنص المادة 28 من القانون القطري على أن : (حقوق المؤلف المنصوص عليها في هذا

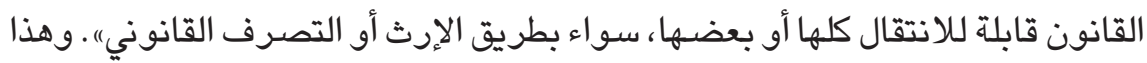

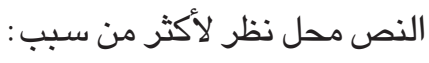

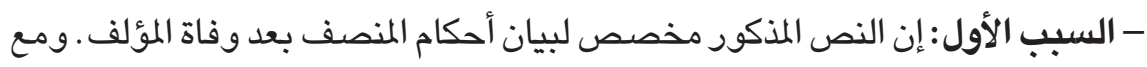

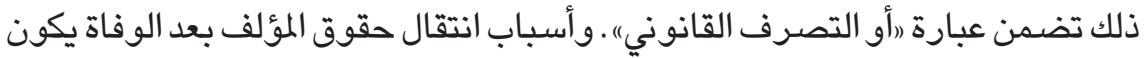

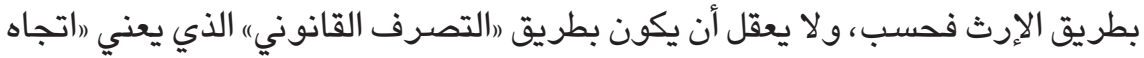

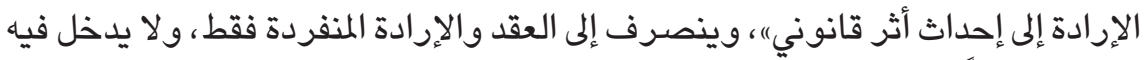

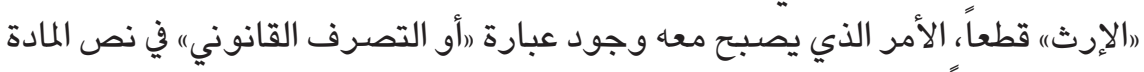
المذكورة، زائداً وليس في محله.

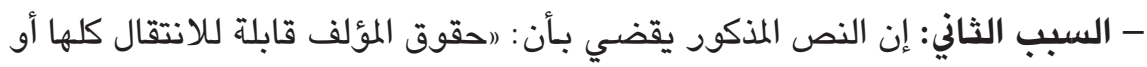

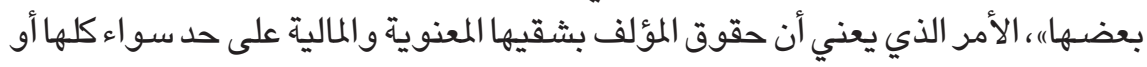

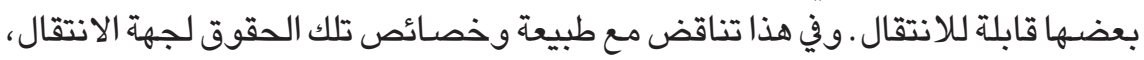
ذلك أن حقوق المؤلف المادية - دون الحقوق المعنوية- تقبل الانتقال كما تقدم البيان. - السبب الثالث: إن النص المذكور لا ينسجم مـع نص المادة الثامنة(1) والتي حصرت -صراحة- حق التصرف في الحقوق المالية فحسب.

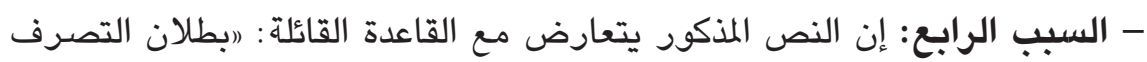

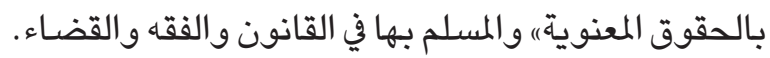

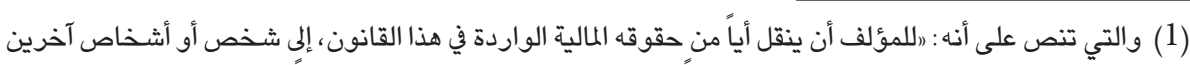

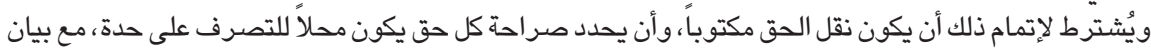

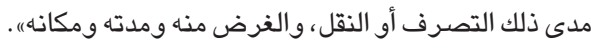




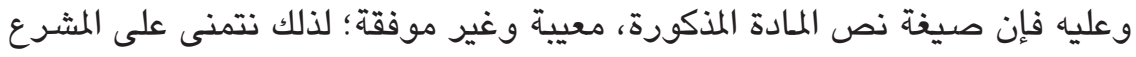

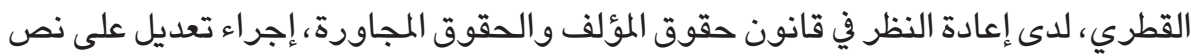
المادة المذكورة بصورة ترفع ما اعتوره من عيوب صياغته المنوه عنها.

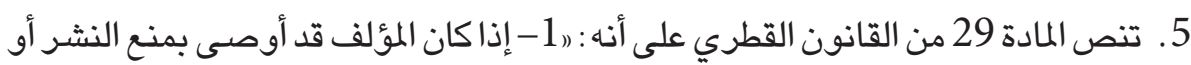

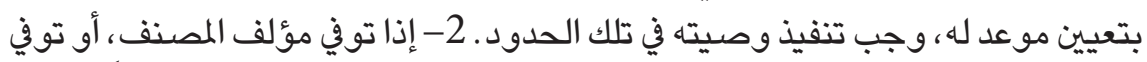
أحد مؤلفي المصنف المشترك بلا وارث، فإن نصيبه يؤول على من من يستحقه وفقاً لأحكام

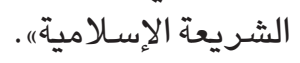

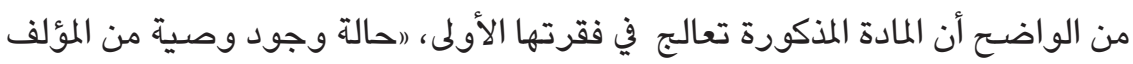

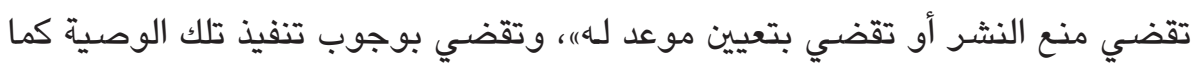

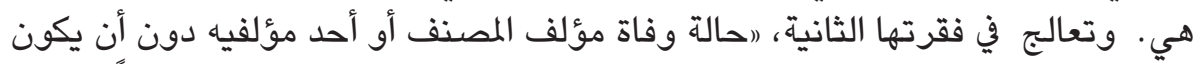

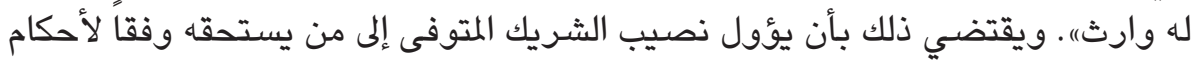

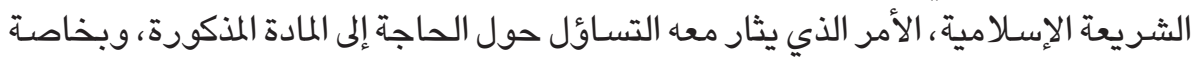

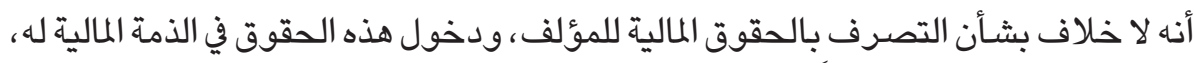

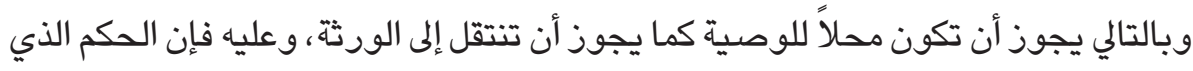

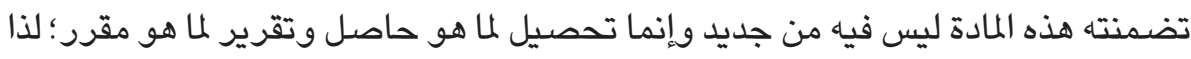

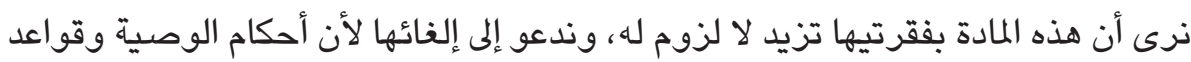

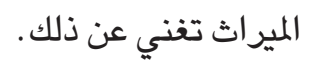

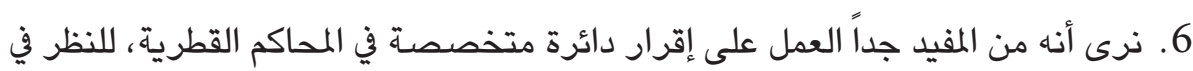

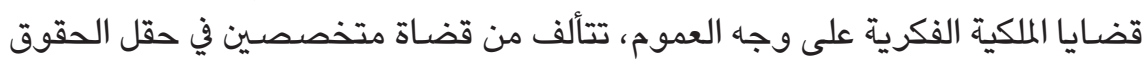

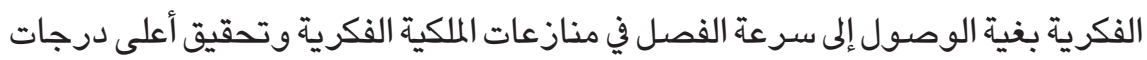
العدالة. 


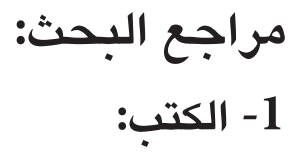

- باسـم محمد ملحم، التأصيل التاريخي التشريعي لحماية عنوان المصنف الأدبي والفني

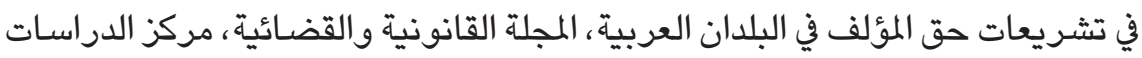

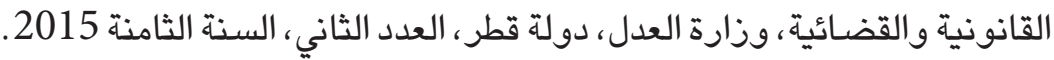
- بول جولدنشتاين، حقوق المؤلف من جوتنبرخ إلى الفونوجراف الآلي الفضـائي، ترجمة

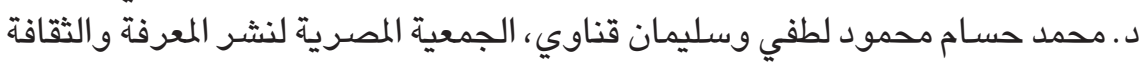

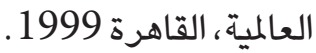

- جمال عبدالرحمن محمد على، والدكتور عادل أبو هشيمة محمود حوته، حقوق الملكية

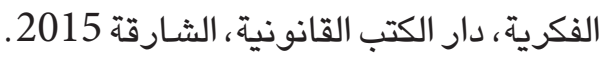

- جورج جبور، الملكية الفكرية، حقوق المؤلف، الطبعة الأولى، دار الفكر، دمشق، 1996. - خاطر لطفي، موسوعة حقوق الملكية الفكرية، شركة ناس للطباعة 2003. - خالد محمد كدفور المهيري، موسوعة الملكية الفكرية موسية 2009. - رمزي رشـاد عبدالرحمن الشيخ، الحقوق المجاورة لحق المؤلف، دار الجامعة الجديدة، الإسكندرية 2005.

- صلاح زين الدين، المدخل إلى الملكية الفكرية، دار الثقافة، عمان، 2004. - صلاح زين الدين، شرح قانون براءات الاختراع القطري، دار وائل للنشر والتوزيع، عمان 2010 - عبد الرزاق السنهوري، الوسيط في شرح القانون المدني، ج8، دار النهضـة العربية، ، القاهرة 1991 - عبدالرشيد مأمون والدكتور محمد سامي عبد الصادق، حق المؤلف والحقوق المجاورة،

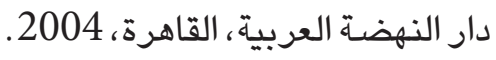

- محمد حسام محمود لطفي، المرجع العلمي في الملكية الأدبية والفنية في ضوء آراء الفقه

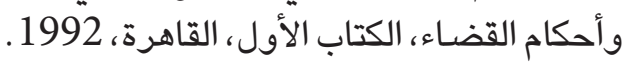

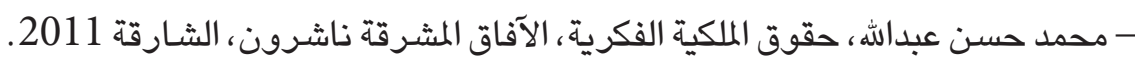
- مختار القاضي، حقوق المؤلف، الكتاب الأول، مكتبة الإنجلو المصرية القاهرة، 1958. 
- ناصر محمد عبداله سلطان، حقوق الملكية الفكرية، الطبعة الأولى، مكتبة الجامعة، الشـارقة 2009 - نواف كنعان، حق المؤلف، الطبعة الثالثة، دار الثقافة، عمان، 2000.

$$
\text { 2- 2 - الأبحاث: }
$$

- حسن جميعي ، مدخل إلى حقوق المؤلف والحقوق المجاورة، القاهرة، 10 اكتوبر 2004، من /

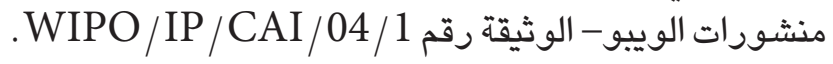

- عمر مشهور حديثة الجازي، المبادئ الأساسية لقانون حق المؤلف، ورقة عمل مقدمة

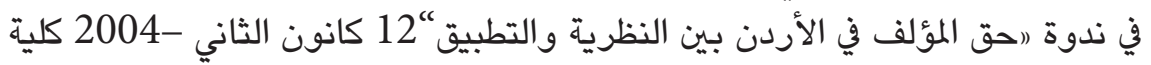

$$
\text { الحقوق - الجامعة الأردنية. }
$$

- فاروق الأباصيري، الإطار القانوني لحقوق هيئات الإذاعة فيمجال بث المسـابقات الرياضية :

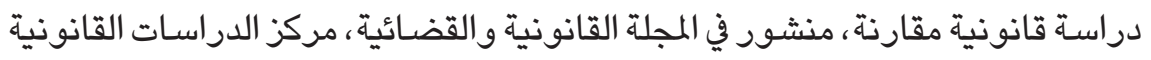

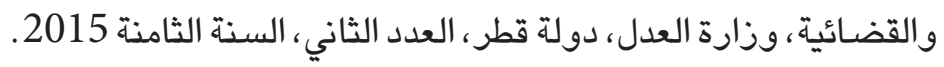

\section{3- القوانين والاتفاقيات الدولية:}

- القانون رقم (7) لسنة 2002 بشأن حماية حق المؤلف والحقوق المجاورة القطري. - قانون حماية حقوق الملكية الفكرية المصري رقم 82 لسنة 2002. - اتفاقية برن لحماية المصنفات الأدبية والفنية لعام 1886م. - اتفاقية اتفاق الجوانب المتصلة بالتجارة من حقوق الملكية الفكرية (تربس TRIPS) لعام

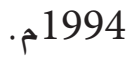


المحتوى:

\begin{tabular}{|c|c|}
\hline | الصفحة & المـوضـوغ \\
\hline 79 & الملخص \\
\hline 79 & 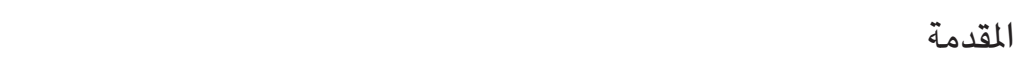 \\
\hline 81 & المبحث الأول- حقوق المؤلف \\
\hline 82 & أولا- حقوق المؤلف \\
\hline 82 & ثانيا- حقوق مجاورة لحقوق المؤلف \\
\hline 83 & المطلب الأول-تعريف المُصنَف والمصنف (المُؤلف) \\
\hline 83 & الفرع الأول - تعريف المُصنَف \\
\hline 85 & الفرع الثاني - تعريف المؤلف \\
\hline 86 & الفرع الثالث - حالات التأليف \\
\hline 86 & 1- حالة وضـع المصنف من مؤلف منفرد (المصنف الفردي) \\
\hline 87 & 2- حالة وضـع المصنف بالاشتراك بين عدد من المؤلفين (المصنف المشترك) \\
\hline 87 & الأولى - حالة المصنف الأدبي \\
\hline 88 & الثانية-- حالة المصنف الفني \\
\hline 89 & الثالثة- حالة المصنف السمعي البصري \\
\hline 91 & 3- حالة وضـع المصنف من فريق من المؤلفين مجتمعين (المصنف الجماعي) \\
\hline 92 & 4- حالة وضع مصنف مشتق من مصنفات سابقة (المصنف المشتق أو المركب) \\
\hline 93 & المطلب الثاني - شروط حماية حقوق المؤلف \\
\hline 93 & الفرع الأول- الشروط الموضوعية \\
\hline 93 & 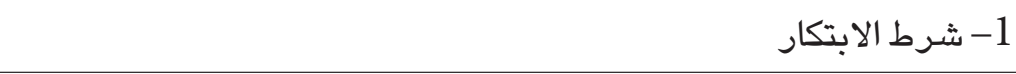 \\
\hline 95 & 2- شرط الإظهار \\
\hline
\end{tabular}




\begin{tabular}{|c|c|}
\hline الصفحة & المـوضـوع \\
\hline 96 & الفرع الثاني - الشروط الشكلية \\
\hline 96 & 1- شروط إيداع المصنفات \\
\hline 98 & 2- 2 - 2ـروط تداول المصنفات \\
\hline 98 & المطلب الثالث - نطاق الحماية القانونية للمصنفات \\
\hline 98 & الفرع الأول- المصنفات المحمية \\
\hline 99 & 1- الكتب والكتيبات وغيرها من المواد المكتوية \\
\hline 99 & 2- المصنفات التي تلقى شفاهة \\
\hline 99 & 3- المؤلفات المسرحية والمسرحيات الموسيقية \\
\hline 99 & 4- المصنفات الموسيقية \\
\hline 100 & 5- مصنفات تصميم الحركات الإيقاعية والتمثيل الإيمائي \\
\hline 100 & 6- المصنفات السمعية والبصرية \\
\hline 100 & 7- المصنفات الفوتوغرافية وما يماثلها \\
\hline 100 & 8-مصنفات الفنون التطبيقية، سواء أكانت حرفية يدوية أم صناعية \\
\hline 101 & 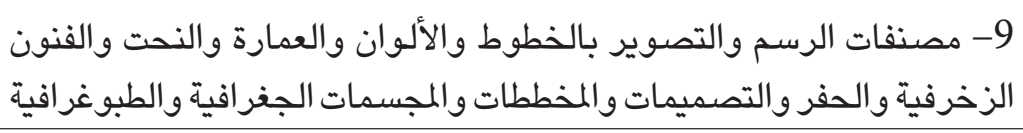 \\
\hline 101 & 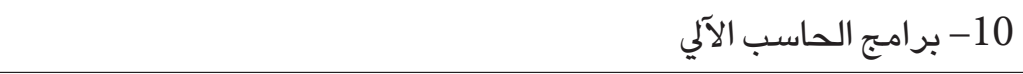 \\
\hline 101 & 11 مصنفات الترجمة والتليص والتعديل والشرح وغيرها من التحويرات \\
\hline 102 & 12 - مجموعة الموضوعات والمختارات إذا كانت مبتكرة من حيث انتقاء المواد \\
\hline 102 & 13- قواعد البيانات، إذا ما كانت هذه المجموعات مبتكرة بسبب ترتيبها، أو \\
\hline
\end{tabular}




\begin{tabular}{|c|c|}
\hline | الصفحة & المـوضـوع \\
\hline 102 & 14 - مبتكرة بسموعة المصنفات ترتيها وأو اختيار محتويرات الفلوكلورية، ، إذا ما كانت هذه المجموعات \\
\hline 103 & 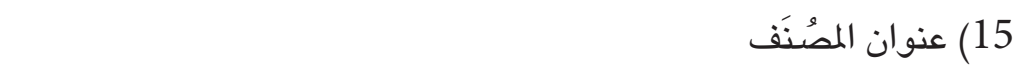 \\
\hline 105 & الفرع الثاني المصنفات غير المحمية \\
\hline 106 & المطلب الرابع- حقوق المؤلف المعنوية والمالية \\
\hline 106 & الفرع الأول - حقوق المؤلف المعنوية \\
\hline 107 & 1) حق المؤلف في تقرير نشر مصنفه لأول مرة: \\
\hline 107 & 2) حق ألمؤلف في أن ينسب إليه المصنف بذكر اسمه عليه، أو باسم مستعار، \\
\hline 108 & 3) حق الاعتراض ومنع كل تحريف أو تشويه أو تعديل آخر لمصنفه: \\
\hline 109 & 4أو سمعته الاعتراض ومنع أي استعمال للمصنف يمكن أن يسيء إلى شرفه \\
\hline 109 & 5) حق سـب مصنفه من التداول أو إجراء أي تعديل بالحذف أو الإضـافة فيه \\
\hline 110 & الفرع الثاني - حقوق المؤلف المالية \\
\hline 111 & 1- استنساخ المصنف \\
\hline 112 & 2- 2 - 2 - 2 20مة المصنف \\
\hline 112 & 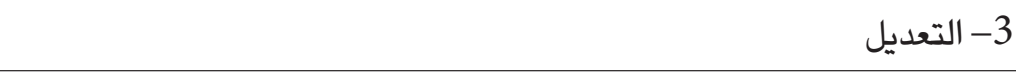 \\
\hline 113 & 4- اقتباس أو توزيع موسيقى، أو إجراء أي تحوير آخر للمصنف \\
\hline 113 & 5- توزيع المصنف على الجمهور من خلال البيع \\
\hline 113 & 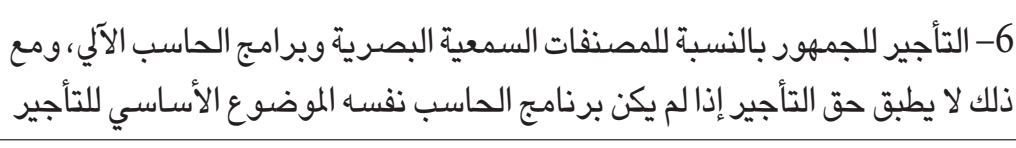 \\
\hline 113 & 7- الأداء العلني للمصنف \\
\hline
\end{tabular}




\begin{tabular}{|c|c|}
\hline الصفحة & المـوضـوضـوع \\
\hline 114 & 8- نقل المصنف إلى الجمهور \\
\hline 115 & الفرع الثالث- مدة حماية حقوق المؤلف المالية \\
\hline 117 & المطلب الخامس- التصرف بحقوق المؤلف المالية \\
\hline 117 & الفرع الأول- نقل حقوق المؤلف المالية \\
\hline 119 & الفرع الثاني - أبرز طرق نقل حقوق المؤلف المالية \\
\hline 119 & 1- تعريف عقد النشر \\
\hline 119 & 2- خصـائص عقد النشر \\
\hline 120 & 3- آثارعقد النشر \\
\hline 122 & الفرع الثالث- القيود الواردة على حقوق المؤلف المادية \\
\hline 17 & الفرع الرابع - أحكام المصنف بعد وفاة المؤلف \\
\hline 130 & المطلب السادس - الحماية القانونية لحقوق المؤلف \\
\hline 130 & الفرع الأول- الحماية الإدارية \\
\hline 131 & الفرع الثاني_- الحماية الإجرائية \\
\hline 134 & الفرع الثالث- الحماية المدنية \\
\hline 134 & الفرع الرابع - الحماية الجنائية \\
\hline 139 & الفرع الخامس- الحماية الدولية \\
\hline 142 & المبحث الثاني- الحقوق المجاورة \\
\hline 142 & المطلب الأول- التعريف بالحقوق المجاورة \\
\hline 142 & الفرع الأول-نشأة الحقوق المجاورة \\
\hline 143 & الفرع الثاني - تعريف الحقوق المجاورة \\
\hline
\end{tabular}




\begin{tabular}{|c|c|}
\hline الصفحة & 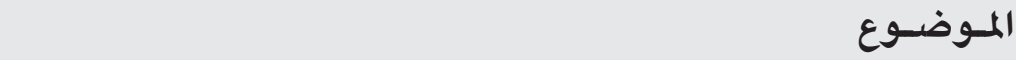 \\
\hline 143 & الفرع الثالث- تحديد أصـحاب الحقوق المجاورة \\
\hline 144 & المطلب الثاني- حقوق أصحاب الحقوق المجاورة والقيود الواردة عليها \\
\hline 144 & الفرع الأول- حقوق أصـحاب الحقوق المجاورة \\
\hline 147 & الفرع الثاني - القيود الواردة على الحقوق المالية لأصـحاب الحقوق المجاورة \\
\hline 147 & المطلب الثالث- الحماية القانونية لأصـحاب الحقوق المجاورة \\
\hline 149 & الصرتية وهيئات الإذاعة لعام الأول الفاقية روما في شأن حماية فناني الأداء ومنتجي التسجيلات 1961 \\
\hline 149 & 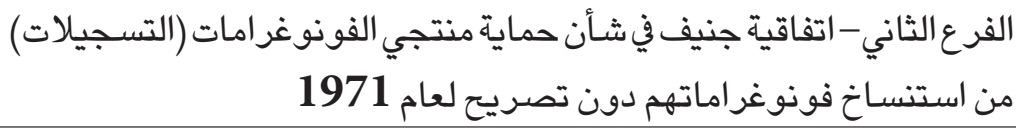 \\
\hline 150 & المرسرعلة الثبر التوابع الفاقية بروكسل بشاعية لعام 1974 توزيع الإثــارات الحاملة للبرامج \\
\hline 150 & (تربس الفرع الرابع - اتفاق الجوانب المتصلة بالتجارة من حقوق الملكية الفكرية 1994 لعابة \\
\hline 152 & الخاتمة (النتائج والتوصيات) \\
\hline 155 & 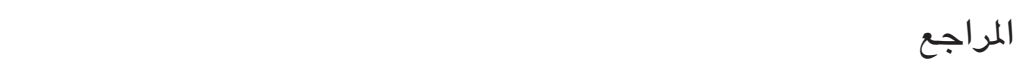 \\
\hline
\end{tabular}

